\title{
Impacts of ocean acidification on marine shelled molluscs
}

Article in Marine Biology · August 2013

DOI: $10.1007 / \mathrm{s} 00227-013-2219-3$

CITATIONS

176

8 authors, including:

Laura M. Parker

University of Sydney

25 PUBLICATIONS 987 CITATIONS

SEE PROFILE

\section{Hans-Otto Pörtner}

Alfred Wegener Institute Helmholtz Centre fo...

547 PUBLICATIONS 21,010 CITATIONS

SEE PROFILE

\section{Sophie Martin}

Station Biologique de Roscoff

62 PUBLICATIONS 2,468 CITATIONS

SEE PROFILE

\section{Pauline Ross}

Western Sydney University

55 PUBLICATIONS 1,406 CITATIONS

SEE PROFILE

Some of the authors of this publication are also working on these related projects: 


\title{
Impacts of ocean acidification on marine shelled molluscs
}

\author{
Frédéric Gazeau • Laura M. Parker · Steeve Comeau • \\ Jean-Pierre Gattuso - Wayne A. O'Connor • \\ Sophie Martin · Hans-Otto Pörtner · Pauline M. Ross
}

Received: 18 January 2013/ Accepted: 15 March 2013

(C) Springer-Verlag Berlin Heidelberg 2013

\begin{abstract}
Over the next century, elevated quantities of atmospheric $\mathrm{CO}_{2}$ are expected to penetrate into the oceans, causing a reduction in $\mathrm{pH}(-0.3 /-0.4 \mathrm{pH}$ unit in the surface ocean) and in the concentration of carbonate ions (so-called ocean acidification). Of growing concern are the impacts that this will have on marine and estuarine organisms and ecosystems. Marine shelled molluscs, which colonized a large latitudinal gradient and can be found from intertidal to deep-sea habitats, are economically and ecologically important species providing essential
\end{abstract}

Communicated by S. Dupont.

Frédéric Gazeau and Laura M. Parker have contributed equally to this work.

Electronic supplementary material The online version of this article (doi:10.1007/s00227-013-2219-3) contains supplementary material, which is available to authorized users.

F. Gazeau · J.-P. Gattuso

Laboratoire d'Océanographie de Villefranche, CNRS-INSU, BP 28, 06234 Villefranche-sur-Mer Cedex, France

F. Gazeau $(\varangle) \cdot$ J.-P. Gattuso

Université Pierre et Marie Curie-Paris 6, Observatoire

Océanologique de Villefranche, 06230 Villefranche-sur-Mer

Cedex, France

e-mail: f.gazeau@obs-vlfr.fr

L. M. Parker $(\bowtie)$. P. M. Ross

School of Natural Sciences, Ecology and Environment Research Group, College of Health and Science, University of Western

Sydney, Hawkesbury H4, Locked Bag 1797, Penrith South DC

1797, Sydney, NSW, Australia

e-mail: 1.parker@uws.edu.au

S. Comeau

Department of Biology, California State University, 18111

Nordhoff Street, Northridge, CA 91330-8303, USA ecosystem services including habitat structure for benthic organisms, water purification and a food source for other organisms. The effects of ocean acidification on the growth and shell production by juvenile and adult shelled molluscs are variable among species and even within the same species, precluding the drawing of a general picture. This is, however, not the case for pteropods, with all species tested so far, being negatively impacted by ocean acidification. The blood of shelled molluscs may exhibit lower $\mathrm{pH}$ with consequences for several physiological processes (e.g. respiration, excretion, etc.) and, in some cases, increased mortality in the long term. While fertilization may remain unaffected by elevated $p \mathrm{CO}_{2}$, embryonic and larval development will be highly sensitive with important reductions in size and decreased survival of larvae, increases in the number of abnormal larvae and an increase in the developmental time. There are big gaps in the current understanding of the biological consequences of an

W. A. O'Connor

Industry and Investment NSW, Port Stephens Fisheries Centre, Taylors Beach, NSW 2316, Australia

S. Martin

Laboratoire Adaptation \& Diversité du Milieu Marin, CNRS-

INSU, Station Biologique de Roscoff, 29682 Roscoff, France

\section{S. Martin}

Laboratoire Adaptation \& Diversité du Milieu Marin, Université

Pierre et Marie Curie, Station Biologique de Roscoff,

29682 Roscoff, France

H.-O. Pörtner

Alfred-Wegener-Institut für Polar-und Meeresforschung,

Ökophysiologie und Ökotoxikologie, Postfach 120161,

27515 Bremerhaven, Germany 
acidifying ocean on shelled molluscs. For instance, the natural variability of $\mathrm{pH}$ and the interactions of changes in the carbonate chemistry with changes in other environmental stressors such as increased temperature and changing salinity, the effects of species interactions, as well as the capacity of the organisms to acclimate and/or adapt to changing environmental conditions are poorly described.

\section{Introduction}

The Mollusca is a very large and highly diverse phylum of invertebrate animals. There are between 50,000 and 120,000 described living molluscan species (Chapman 2009) among which around 30,000 species are found in marine environments (23\% of all marine organisms; Gosling 2003). Among the six classes of this phylum (Gastropoda, Bivalvia, Cephalopoda, Polyplacophora, Scaphopoda and Monoplacophora), gastropods (i.e. stomach-foot) and bivalves are the largest classes ( $>80 \%$ of described living marine molluscan species). Information on the effects of ocean acidification is, to the best of our knowledge, only available for Gastropoda, Bivalvia and Cephalopoda. Besides the important differences in terms of life cycle and metabolism between bivalves/gastropods and cephalopods, only in one order of cephalopods (nautilus), have organisms developed an external shell. For these reasons, this review paper will only focus on marine bivalves and gastropods (hereafter referred to as marine shelled molluscs). Marine shelled molluscs have a complex life cycle, which often includes a pelagic embryonic and larval stage followed by a benthic (sometimes sessile) juvenile and adult stage. Furthermore, shelled molluscs are found in a wide variety of ecological niches in marine, freshwater and terrestrial habitats. For instance, gastropods can be found from the poles to the tropics as they adapt to a wide range of environmental conditions on Earth, having colonized aquatic and terrestrial habitats. Although some of the most familiar gastropods are terrestrial (snails and slugs), more than two-thirds of all extant species live in a marine environment. Although gastropods are mostly associated with life in intertidal rocky-shore habitats, they can be found in deep basins and have been found in extreme environments close to hydrothermal vents (e.g. Suzuki et al. 2006). In contrast to gastropods, bivalves only exist in aquatic environments. In the sea, they also colonize a large latitudinal gradient and can be found from intertidal to deep-sea habitats (e.g. Tunnicliffe et al. 2009).

As detailed in the following section, shelled molluscs provide essential ecosystem services including the formation of habitat structure for benthic organisms (e.g. mussel and oyster beds), water purification as well as being a food source for other organisms in their ecosystem. In addition, shelled molluscs have a significant economic value as the global shellfish aquaculture industry reached a global value of US\$ 13.1 billion in 2008 (FAO 2008). In recent decades, severe declines in shelled mollusc populations have been reported. Surveys conducted annually along the coast of British Columbia have shown a decline of up to $80 \%$ in some populations since 1978 (Hankewich and Lessard 2006). Moreover, in hatcheries located on the northwest coast of the USA, there has been a year-by-year decline in the survival of oyster larvae since 2005, which appears to be connected to the upwelling of acidified deep waters shifting coastward and associated near-shore ocean acidification (Barton et al. 2012). Indeed, Feely et al. (2008) have noticed that even though seasonal upwelling of waters undersaturated with aragonite (one of the most soluble metastable forms of calcium carbonate) is a natural feature on the northern California shelf, the uptake of anthropogenic $\mathrm{CO}_{2}$ has increased the affected area over recent decades.

Ocean acidification poses a threat for ecologically and economically important shelled molluscs. Losses in species numbers and population densities due to ocean acidification would further drive habitat restructuring, changes in food webs, losses of marine resources for human society as well as job losses for those working in industries associated with shelled molluscs (Newell 2004). In the present review, we will discuss the ecological and biogeochemical roles played by shelled molluscs and the use of these species by humans through aquaculture activities. We will then describe the present knowledge on the formation of the shell and review the current literature on the effects of ocean acidification on adults, juveniles and early-life-history stages of shelled molluscs. Finally, we will highlight the current gaps in our understanding and the need for future research.

\section{A short primer on marine shelled molluses}

Ecological and biogeochemical importance of marine shelled molluscs

Shelled marine molluscs are recognized as key species at the ecosystem level, as they have the potential to impact both community structure and ecosystem functioning. Most bivalve molluscs are suspension-feeders that clear seston particles greater than $\sim 1$ to $7 \mu \mathrm{m}$ from the water column (Winter 1978). They have major effects on the degradation of pelagic organic matter and divert energy flow from planktonic to benthic food webs. By filtering phytoplankton and other planktonic particles, bivalves assist in "clearing" the water (Asmus and Asmus 1991) and 
increasing the penetration of light in the water column. The resulting enhanced light availability is essential for the growth of macro- or micro-phytobenthic plants and algae, which therefore benefit from bivalves in coastal ecosystems (e.g. Miller et al. 1996; Newell and Koch 2004). Feeding behaviours in gastropoda are more diverse as marine gastropods include some that are herbivores, detritus feeders, predatory carnivores, scavengers, parasites and also a few ciliary feeders, in which the radula is reduced or absent

In most shelled molluscs, much of the captured particles are not ingested but are rejected as pseudofaeces (Bayne and Hawkins 1992). Organic matter that escapes assimilation together with organic matter rejected as pseudofaeces forms biodeposits which provide an organic substrate for macro- and/or micro-organisms living on top or within the sediment and therefore have the potential to locally increase biodiversity (e.g. Norling and Kautsky 2007). Through their excretion of ammonium and urea and through the biomineralization of the biodeposits, shelled molluscs significantly affect microbial activities (e.g. nitrification) and nutrient regeneration from the sediment (Lavrentyev et al. 2000; Martin et al. 2006), therefore providing essential nutritive elements back to the planktonic compartment and favouring phytoplankton growth. However, the presence of shelled molluscs is not always beneficial for ecosystems as several studies reported sediment over-enrichment by shelled mollusc biodeposits in areas with very high shelled mollusc densities, for instance in places where intensive shellfish aquaculture occurs and where invasive species develop (Grant et al. 1995). Excessive biodeposition can stimulate bacterial biomineralization in the sediment with the consequence of high oxygen consumption driving the sediment into anoxia and significantly decreasing biodiversity (Castel et al. 1989).

Besides these complex impacts on ecosystem functioning, shelled molluscs have important benefits for benthic communities through the production of their shell. It is an important substratum for the attachment of epibionts and for providing refuges from predation, physical or physiological stress (Gutiérrez et al. 2003). Through the production of their shell, shelled molluscs also have the potential to act as significant sources of $\mathrm{CO}_{2}$. Indeed, calcification induces a shift in the seawater carbonate equilibrium generating $\mathrm{CO}_{2}$ (Frankignoulle et al. 1995) that can ultimately be released to the atmosphere. As shelled molluscs also produce respiratory $\mathrm{CO}_{2}$, they can enhance the capacity of an ecosystem to act as a net $\mathrm{CO}_{2}$ source to the atmosphere (Chauvaud et al. 2003; Martin et al. 2006, 2007). However, although benthic shelled molluscs have been shown to be important contributors to the carbon cycle locally (e.g. Smith 1972; Beukema 1980; Beukema 1982; Beukema and Cadee 1999; Saha and Jana 1999), there has been, to date, no attempt to estimate their contribution to the carbon cycle on a global scale. In contrast to benthic shelled molluscs, there have been attempts to estimate the contribution of shell production by pteropods (planktonic gastropods with a shell made out of aragonite) although these estimates are wide-ranging, from 10 to $50 \%$ of the total global $\mathrm{CaCO}_{3}$ flux (Berner 1977; Berger 1978; Berner and Honjo 1981; Fabry and Deuser 1991).

To conclude, shelled molluscs play a significant and complex role in their marine and estuarine ecosystems, with various positive and negative consequences for their associated communities and the entire ecosystem. Accordingly, there currently is an emphasis on strategies for shellfish bed restoration to ecosystems they had been removed from due to human activities, with the objective to increase water quality by filtration of suspended particles and phytoplankton (Coen et al. 2007).

Economical value of marine shelled molluscs

Humans have cultured aquatic organisms as a food source for millennia. For instance, Romans practiced oyster farming near Naples (Italy) in the first century BC. Mussel farming dates back to the thirteenth century, while clam and scallop farming appear to be more recent and first occurred in China and Japan in the last few centuries (Gosling 2003). Nowadays, around 100 different shellfish species (both freshwater and marine) are cultivated commercially. The shellfish industry has grown quickly during recent decades with aquaculture increasing from only $25 \%$ of total shellfish fisheries production in 1950 to greater than $80 \%$ today (Fig. 1a). More than $95 \%$ of the worldwide oyster production now comes from aquaculture (compared to $98 \%$ for carpet shells and $77 \%$ for mussels). The global shellfish aquaculture industry reached a production of 13.1 million tons in 2008 and a global value of US\$ 13.1 billion (27 and $12 \%$ of total aquaculture values, respectively; FAO 2008).

Based on FAO data, most shellfish production takes place in marine environments and oyster farming is the dominant activity (32\%; Fig. 1b). The most cultivated species are, in order of decreasing importance, the Pacific oyster (Crassostrea gigas), the Portugese oyster (Crassostrea angulata) and the Eastern oyster (Crassostrea virginica). With more than $80 \%$ of world production, China is the main oyster producer. Clams are the second most cultivated group of bivalves ( $23 \%$, Fig. 1b), the most important species being the Japanese carpet shell (Ruditapes philippinarum) with more than $97 \%$ of the production taking place in China. Mussels rank third among shelled molluscs cultivated worldwide in terms of production, with one-third in China. Twelve species are reared, the most common ones being the Asian green 


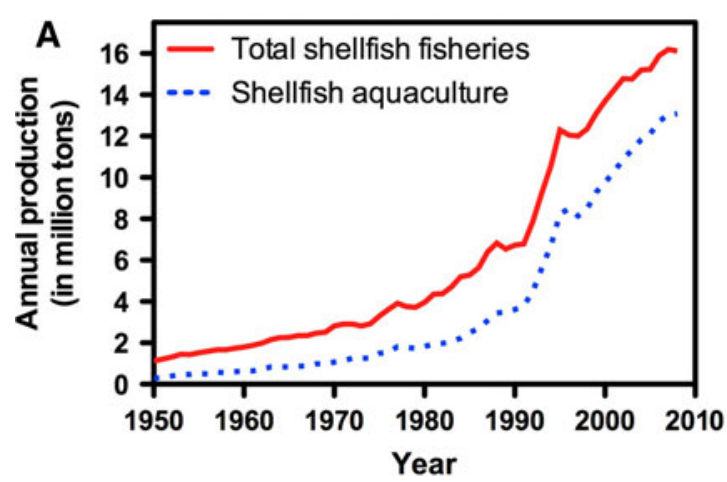

Fig. 1 a Evolution of total shellfish fisheries annual productions (solid line) and shellfish aquaculture annual productions (dotted line) between 1950 and 2008. b Repartition of the shellfish aquaculture

mussel (Perna viridis), the blue mussel (Mytilus edulis) and the Chilean mussel (Mytilus chilensis).

Climate change will, most certainly, have profound effects on this industry. Temperature increase, sea-level rise, modifications in precipitation regimes and increases in the occurrence and strength of extreme events can have negative impacts on aquaculture. Ocean acidification has recently been recognized as a potentially threatening climate change-related mechanism (FAO 2008).

\section{Impacts of ocean acidification}

In the following sections, the effects of ocean acidification on marine shelled molluscs are presented and discussed as the observed responses to an experimental $\mathrm{pH}$ offset from ambient conditions. This parameter $(\mathrm{pH})$, rather than other important parameters of the carbonate chemistry that will change as a consequence of anthropogenic $\mathrm{CO}_{2}$ invasion, has been chosen as the baseline for comparisons between studies. First of all, $\mathrm{pH}$ is the most frequently reported parameter in the literature and, for a similar $\mathrm{pH}$ perturbation, the highly variable chemical conditions (temperature, salinity, alkalinity) of the coastal ocean where the vast majority of shelled molluscs can be found lead to very diverse carbonate ion concentrations and saturation states that prevent efficient comparisons. Furthermore, as in coastal areas, $p \mathrm{CO}_{2}$ (pH levels) can be already relatively high (low; see section "Environmental conditions versus laboratory conditions" for more details), presenting data as an offset from these ambient conditions appeared necessary. Nevertheless, all relevant and available parameters of the carbonate chemistry, considered in these studies, have been compiled and presented in the supplementary table. Given that the effects of ocean acidification are likely to differ between pelagic and benthic life stages of shelled molluscs owing to their differences in physiology, habitat

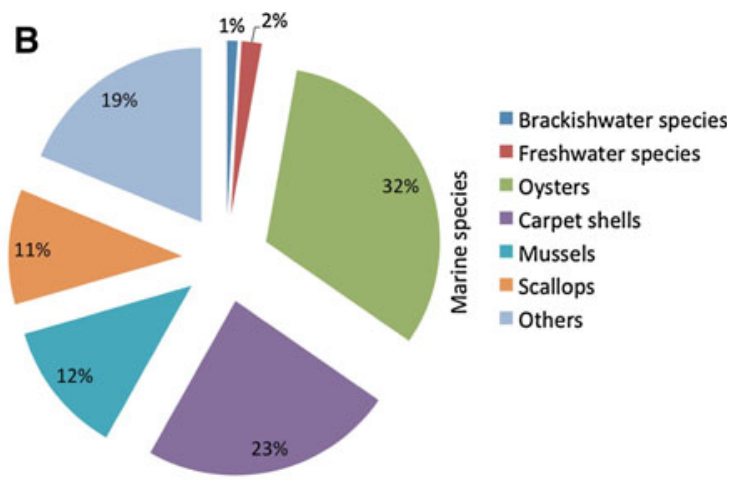

production in 2008 among freshwater, brackish water and seawater species (source: FAO 2008)

and behaviour, these life stages are treated separately. Note that pteropods are holoplanktonic molluscs spending their entire life cycle in the pelagic compartment; they will be considered in a separate section ("Pteropods").

\section{Early studies}

To our knowledge, the first study of the effects of $\mathrm{pH}$ on a marine shelled mollusc was performed by Loosanoff and Tommers (1947). All "early" perturbation experiments are not useful in the context of anthropogenic $\mathrm{CO}_{2}$ as most of them used $\mathrm{pH}$ values that were far below the values projected in 2100 (Loosanoff and Tommers 1947; Kawatani and Nishii 1969; Knutzen 1981; Bamber 1987, 1990; Harris et al. 1999; Fig. 2). Nevertheless, these studies provided interesting information. First of all, based on these results, it seems that $\mathrm{pH}$ values expected for the end of the century are not likely to have a lethal effect on shelled mollusc species, at least over exposure times ranging from 8 to 30 days. However, as stated by some of these authors, the most sensitive process to decreasing $\mathrm{pH}$ appears to be shell dissolution that can occur upon exposure to $\mathrm{pH}$ values slightly above 7.5. A decrease in shell resistance due to increased dissolution might increase the predation pressure on these organisms, a hypothesis that has not been tested by any of these "early" studies, which were performed in the laboratory under optimal conditions and without the presence of predators. Furthermore, the fact that some species are able to produce a shell even under very low $\mathrm{pH}$ conditions demonstrates the strong control exerted by shelled molluscs over their calcification process and their capacity to create optimal conditions at the site of calcification through complex mechanisms that remain largely uncharacterized. Finally, as the great majority of these studies do not report alkalinity data and the $\mathrm{pH}$ scale, it is not possible to compute the saturation state of sea water with respect to calcium carbonate. It is 
Fig. 2 Effects of decreasing $\mathrm{pH}$ levels on shelled molluscs: "early studies", see section "Early studies" for details

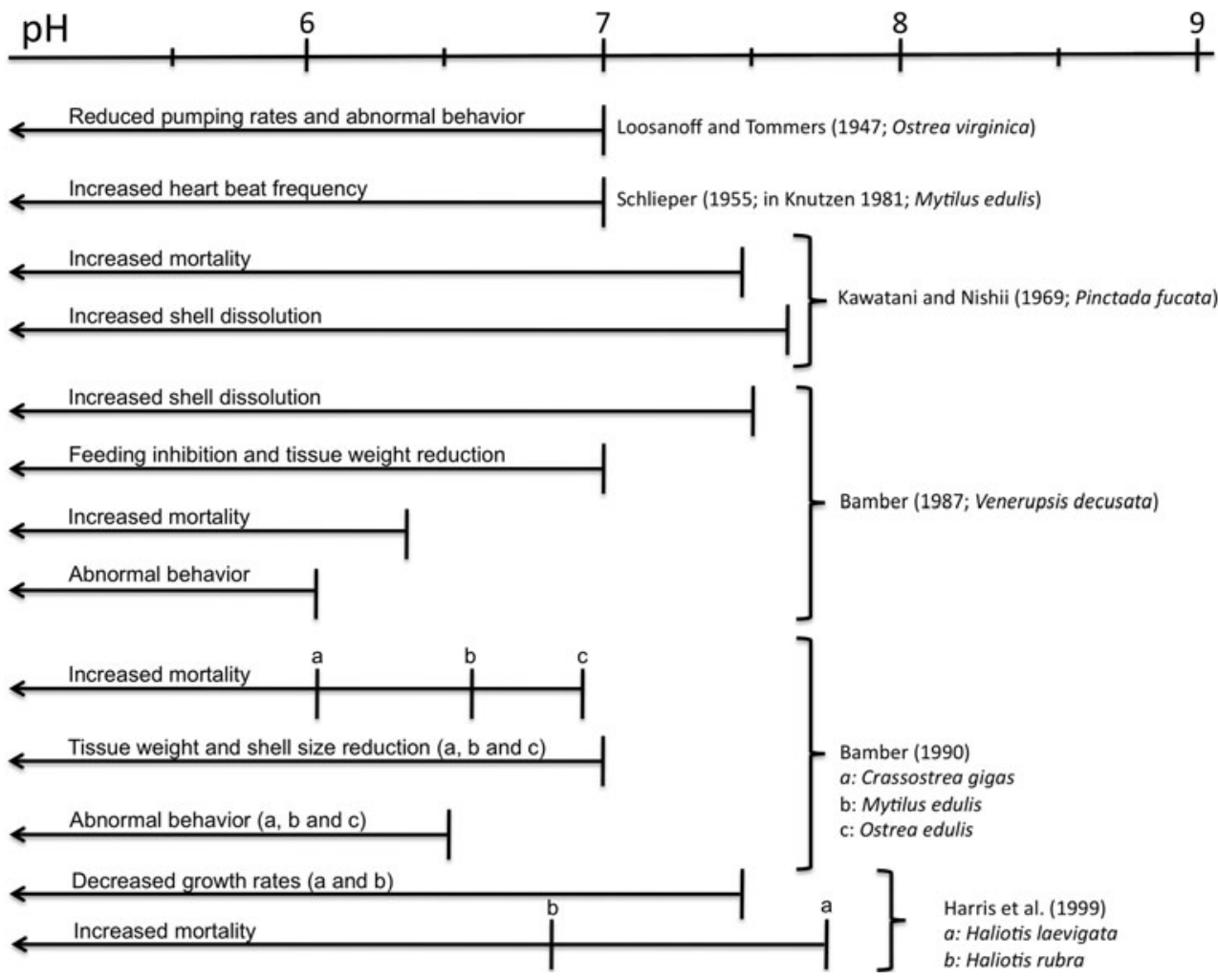

very likely that, due to acidification of the water by fixed acid addition, a decrease in alkalinity occurs such that the organisms (i.e. their shell surfaces facing ambient seawater) experienced corrosive conditions in most of the perturbation treatments.

Adults and juveniles

\section{Calcification and shell growth}

The great majority of molluscs have developed external calcified structures to support their living tissues, protect themselves against predators and exclude mud and sand from the mantle cavity for burrowing species. Shell calcification occurs in a small compartment, the extrapallial cavity (EPC), located between the calcifying outer mantle and the shell itself (Fig. 3). The shell is a composite biomaterial, composed of a mineral phase (95-99\% predominantly calcium carbonate) and an organic matrix (1-5\%). Adult molluscan shells are commonly comprised of aragonite, sometimes calcite and, in certain taxa, layers of both calcite and aragonite (Addadi et al. 2006). Shell organic matrices are essential to form the shell structures (Marin and Luquet 2004).

Mollusc shells are initially produced during their larval development, at the end of the gastrulation phase, following an increase in thickness of epithelial cells that will define the future shell field (Marin and Luquet 2004). When shell field cells invaginate to form the shell gland, the remaining surface cells start to produce the outermost organic shell layer, the periostracum (Eyster 1986). Following the secretion of the periostracum, the inner part of the shell gland evaginates while transforming into the larval mantle epithelium (Kniprath 1981) and the periostracum spans the whole shell field epithelial surface. The primary mineralization takes place between the periostracum and the shell field. Between bivalves and gastropods, the terminology used to define the evolution of the shell during larval development is quite different. In bivalves, the early shell is called the prodissoconch I. The first form of calcium carbonate produced is most likely in the form of amorphous calcium carbonate (ACC) that will evolve more or less rapidly, depending on the species, to aragonite. Transformation into the motile veliger larva then occurs, and the prodissoconch I enlarges to form prodissoconch II. The final shell (dissoconch) is produced at the end of larval development following the metamorphosis of the veliger larvae into a juvenile specimen. In gastropods, the first shell is also produced at the end of the trochophore stage and is called the protoconch I. The protoconch II is produced by veliger larvae and the final shell, called the teleoconch, is produced, similar to bivalves, after metamorphosis into juvenile organisms.

The shell production of molluscan species is a "biologically controlled process". As mentioned earlier, calcification occurs in a closed compartment where ions can 
diffuse or be pumped to increase their concentrations (Fig. 3) and the organism produces organic compounds that help crystal synthesis (nucleation), selecting the calcium carbonate polymorph (calcite or aragonite), defining the morphology and the shape of the crystal and finally interrupting its growth. It has been hypothesized that shelled molluscs increase the calcium carbonate saturation state in the extrapallial fluid (EPF) by adding calcium and/ or carbonate ions by passive transport or active pumping (Crenshaw and Neff 1969; Ip et al. 2006). Moreover, shelled molluscs would make use of the enzyme carbonic anhydrase (CA) that catalyses the conversion of $\mathrm{CO}_{2}$ to bicarbonate and vice versa. It is a widespread metalloenzyme that has been found, for instance, in the protein matrix of the oyster nacreous layer (Miyamoto et al. 1996). Mineralized tissues of shelled molluscs are formed by the initial elaboration of a structural organic framework composed of proteins and polysaccharides into which ions of the mineral phase permeate and crystallize (Weiner and Traub 1984). This insoluble shell matrix is known for more than one and half century (Marin and Luquet 2004). However, an insoluble fraction of these organic macromolecules has been detected (Crenshaw and Neff 1969), which is nowadays believed to play significant roles in the nucleation of crystals and on the inhibition of their growth (Wheeler 1992). We refer to the extensive review of Marin and Luquet (2004) for a detailed description of conchiferan shell proteins and their function in the different processes involved in shell mineralization.
For some authors, the volume of saturated calcium carbonate solution needed for shell calcification is too large to be provided solely by ion concentrating mechanisms in the EPF (Addadi et al. 2006). Although it is assumed that mineral deposition must occur from a saturated solution, it is possible that supersaturation is reached only at the site of nucleation and that undersaturated conditions are maintained elsewhere (Weiner and Dove 2003). Recent support of this hypothesis was provided by Thomsen et al. (2010) who did not identify a regulation of the EPF pH and suggested that the inner shell layers are exposed to highly undersaturated conditions in the bulk of the EPF. High rates of calcification may be found at the shell edge involving the outer mantle and a restricted compartment separate from the EPF. Addadi et al. (2006) mention the hypothesis that crystal nucleation occurs intracellularly, as shown by Mount et al. (2004), and that these initial mineral phases, mostly in the form of ACC, are transported to the mineralization front in order to facilitate aragonite or calcite crystallization. ACC is increasingly believed to be the first-formed phase produced by adult shelled molluscs (Nassif et al. 2005).

Besides $\mathrm{pH}$ and carbonate ion concentrations, the shell production is sensitive to various environmental factors. As with many other physiological processes, shell production is significantly influenced by temperature, with numerous reports showing higher shell growth rates with increasing temperatures (e.g. Malone and Dodd 1967), optimal temperature levels (Almada-Villela et al. 1982) and opposite
Fig. 3 Molluscan shell calcification process (adapted from Marin and Luquet 2004). The calcification of the growing shell takes place at the distal border of the shell, in a compartment-the extrapallial space containing the extrapallial fluid-enclosed by the calcifying epithelium, the periostracum and the shell itself

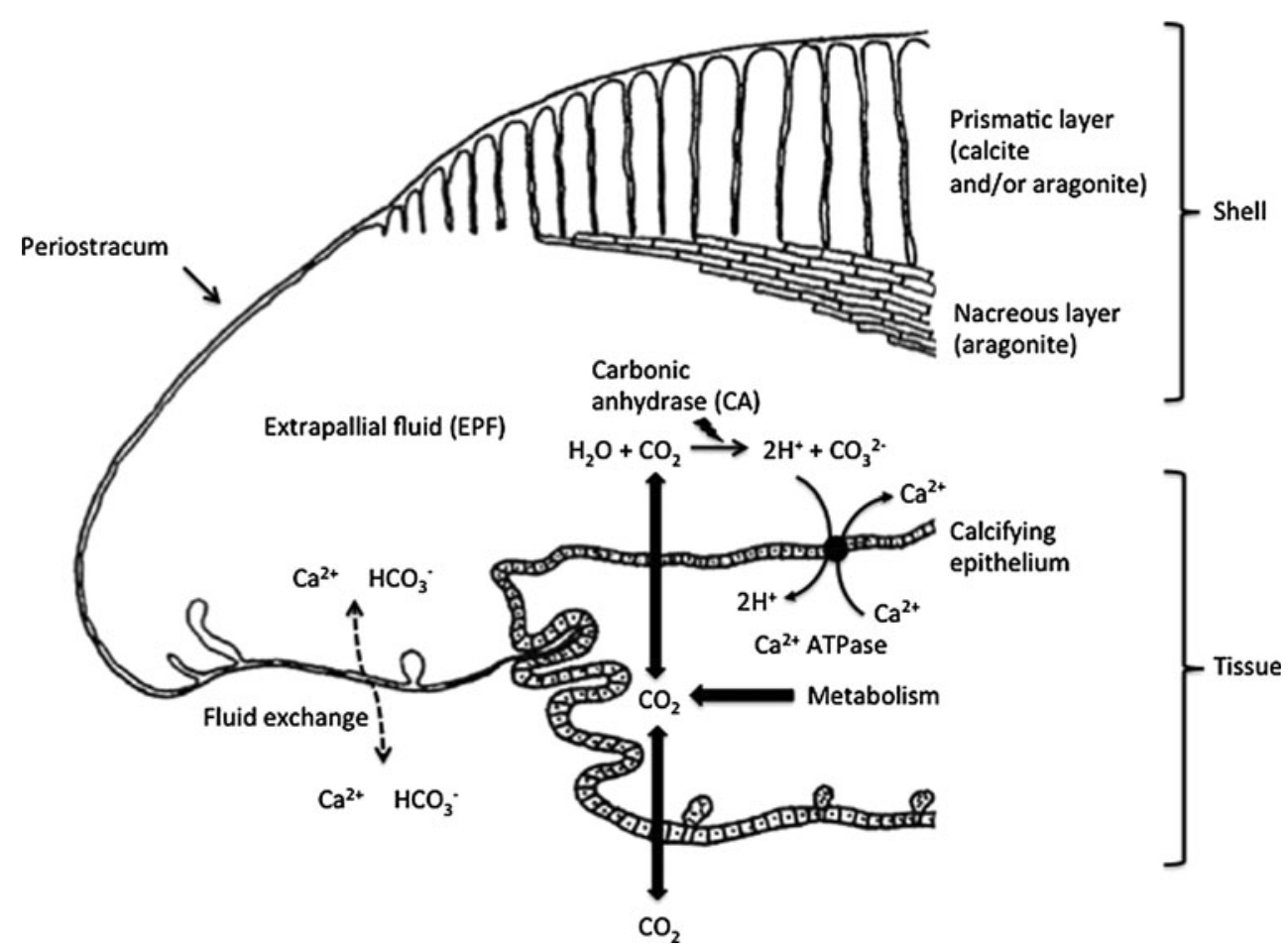


effects of acute versus chronic exposure to higher temperatures (e.g. Nielsen 1988). These strong variations of shell growth rates among species and the possible interaction of other factors influencing growth bring a lot of uncertainties to the use of shelled molluscs for sclerochronological temperature reconstructions (Schöne et al. 2003). Among these other factors, salinity has received considerably less attention with some reports of increased shell growth with increases in salinity over short incubation periods (e.g. Malone and Dodd 1967), the capacity to acclimate over several weeks to abrupt changes in salinity (Almada-Villela 1984) and combined effects of food availability, temperature and salinity on the survival and growth of larvae (Davis and Calabrese 1964).

To conclude, calcification of shelled molluscs and its control by environmental factors are complex issues that are not fully understood. As we will discuss later, the capacity of these species to grow in the future will depend on their capacity to maintain these mechanisms under modified environmental conditions.

In the context of anthropogenic $\mathrm{CO}_{2}$ accumulation in the ocean and the associated decrease in seawater $\mathrm{pH}$ (Table 1), several studies have focussed on calcification and growth. A significant proportion of these papers (6 out of 22) considered solely a $\mathrm{pH}$ decrease stronger than the one projected for the end of the present century $(>-0.4)$. As such, these results will be discussed separately. Michaelidis et al. (2005) and Berge et al. (2006) studied the effect of decreased $\mathrm{pH}(\geq-0.75$ and $\geq-0.5 \mathrm{pH}$ unit, respectively) on two close species, respectively, the Mediterranean mussel and the blue mussel, over medium-term experiments (90 and 44 days, respectively). Both studies showed significant decreased shell growth (as measured by the linear increase of the shells) following $\mathrm{pH}$ reductions of -0.75 and $-1 \mathrm{pH}$ unit, for Michaelidis et al. (2005) and Berge et al. (2006), respectively. Similar reductions in shell growth, following medium-term exposures ( $>2$ weeks) to strong $\mathrm{pH}$ decrease $(>-0.5 \mathrm{pH}$ unit), have been reported by Beniash et al. (2010) and Talmage and Gobler (2011) for juvenile Eastern oysters (Crassostrea virginica). Interestingly, in the study of Beniash et al. (2010), in contrast to shell mass, the average shell area was not affected by hypercapnic conditions, suggesting that juvenile oysters were depositing thinner shells. This further indicates that shell length or area might not be sufficiently accurate as indicators of the effects of ocean acidification on shelled molluscs as the organisms are potentially able to maintain a normal linear shell growth under low $\mathrm{pH}$ conditions. Shell dissolution might outcompete carbonate deposition consistently, resulting in thinner and lighter shells with maintained surface area. The shell thickness of the periwinkle Littorina littorea significantly declined following a strong decrease in seawater $\mathrm{pH}(-1.3$, water undersaturated with respect to both aragonite and calcite; Bibby et al. 2007). Interestingly, while in the presence of predators (crabs), organisms appeared unable to increase shell thickness at low $\mathrm{pH}$, a physiological trait employed by the species under ambient $\mathrm{pH}$ conditions for improved protection, this species compensated for the decrease in morphological defence capacity, however, through a modification of their behaviour (increased capacity to avoid predators at low $\mathrm{pH}$ ). Another technique to estimate shell growth is to directly measure calcification rates through the effect of this process on the surrounding environment. Gazeau et al. (2007) and Waldbusser et al. (2010, 2011b) used the alkalinity anomaly technique (Smith and Key 1975) to show significant decreases in calcification rates with decreasing $\mathrm{pH}$ levels. However, it should be stressed that these studies were performed during very short-term incubations (8-15 h) and should therefore be considered with caution, as they did not leave enough time for the organisms to acclimate.

The first study of the effect of ocean acidification on a shelled mollusc at environmentally relevant $\mathrm{pH}$ levels and over relevant time scales was conducted by Shirayama and Thornton (2005) on juveniles of the strawberry conch (Strombus luhuanus). Growth and survival were recorded over a 180-day exposure period (remaining the longest $\mathrm{CO}_{2}$ perturbation experiment conducted on a shelled mollusc to date) under control and low $\mathrm{pH}$ conditions $(-0.04 \mathrm{pH}$ unit). Unfortunately, $\mathrm{pH}$ is the only parameter of the carbonate system reported, preventing the calculation of $p \mathrm{CO}_{2}$ and $\mathrm{CaCO}_{3}$ saturation state (supplementary Table 1). This gastropod appeared particularly sensitive to elevated $p \mathrm{CO}_{2}$ conditions, as it has been observed that the moderate decrease in seawater $\mathrm{pH}(-0.04 \mathrm{pH}$ unit) elicited statistically significant decreases in survival and growth rate. While no mortality was reported under control conditions, $10 \%$ of the population (3 animals over 30) was lost after 26 weeks of exposure to the low $\mathrm{pH}$ level. A decrease in shell height and wet weight was also reported. To date, this is the only study suggesting that a very moderate decrease in seawater $\mathrm{pH}$ has the potential to adversely affect a gastropod species over a 6-month exposure.

Ries et al. (2009) conducted a comprehensive study of the effects of elevated $\mathrm{CO}_{2}$ levels over an experimental period of 60 days, on eighteen benthic species among which nine were shelled molluscs. These authors considered $3 \mathrm{pH}$ decreases ranging from -0.1 to $-0.7 \mathrm{pH}$ unit. A different analysis of data from Ries et al. (2009) was performed. As the $\mathrm{pH}$ range covered in this study is more important than $\mathrm{pH}$ projections for the next 100 years or so, shell growth rates obtained at each $\mathrm{pH}$ level were compared (using Student's $t$ tests) to the values obtained under control conditions, and data obtained for a $\mathrm{pH}$ decrease greater than $-0.4 \mathrm{pH}$ unit were treated separately. For the blue 
Table 1 Summary of the impacts of ocean acidification on juvenile and adult shelled molluscs

\begin{tabular}{|c|c|c|c|c|c|c|c|c|c|c|c|c|}
\hline \multicolumn{3}{|l|}{ Adults and juveniles } & \multicolumn{10}{|c|}{$\mathrm{pH}$ (unit decrease from ambient) } \\
\hline \multirow{2}{*}{$\begin{array}{l}\text { Author/acclimation time } \\
\text { Species }\end{array}$} & \multirow[t]{2}{*}{ Process-impact } & & \multicolumn{4}{|c|}{ Projected 2100} & \multicolumn{6}{|c|}{ Projected 2300} \\
\hline & & & -0.1 & -0.2 & -0.3 & -0.4 & -0.5 & -0.6 & -0.7 & -0.8 & -0.9 & $>-1.0$ \\
\hline \multicolumn{13}{|l|}{ Bivalves } \\
\hline \multicolumn{13}{|l|}{ Amaral et al. (2012; 70 days) } \\
\hline \multirow{2}{*}{$\begin{array}{l}\text { Saccostrea glomerata } \\
\text { (oyster) }\end{array}$} & Survival & $=$ & & & & & & & & $\bigcirc$ & $\bigcirc$ & $\bigcirc$ \\
\hline & Shell growth & $\downarrow$ & & & & & & & & $\bullet$ & $\bullet$ & $\bullet$ \\
\hline \multicolumn{13}{|l|}{ Beesley et al. (2008; 60 days) } \\
\hline \multirow[t]{3}{*}{ Mytilus edulis (mussel) } & Health & $\downarrow$ & $?$ & $?$ & & & & $?$ & & & & \\
\hline & Tissue structure & $=$ & $\bigcirc$ & $\bigcirc$ & & & & O & & & & \\
\hline & Survival & $=$ & $\bigcirc$ & 0 & & & & O & & & & \\
\hline \multicolumn{13}{|l|}{$\begin{array}{l}\text { Beniash et al. ( } 2010 \text {; } \\
\text { 14-140 days) }\end{array}$} \\
\hline \multirow{6}{*}{$\begin{array}{l}\text { Crassostrea virginica } \\
\text { (oyster) }\end{array}$} & Survival & $\downarrow$ & & & & & & & & $\bullet$ & & \\
\hline & Shell growth & $\downarrow$ & & & & & & & & $\bullet$ & & \\
\hline & Tissue growth & $\downarrow$ & & & & & & & & $\bullet$ & & \\
\hline & Shell structure & $\downarrow$ & & & & & & & & $\bullet$ & & \\
\hline & Shell mineralogy & $=$ & & & & & & & & $\bigcirc$ & & \\
\hline & Respiration & $\uparrow$ & & & & & & & & $\bullet$ & & \\
\hline \multicolumn{13}{|l|}{ Berge et al. (2006; 44 days) } \\
\hline \multirow[t]{2}{*}{ Mytilus edulis (mussel) } & Shell growth & $\downarrow$ & & & & & $\bigcirc$ & & O & & & $\bullet$ \\
\hline & Survival & $\downarrow$ & & & & & O & & ○ & & & $\bullet$ \\
\hline \multicolumn{13}{|l|}{ Bibby et al. (2008; 32 days) } \\
\hline \multirow[t]{2}{*}{ Mytilus edulis (mussel) } & Immune response & $\downarrow$ & & $\bullet$ & & $\bullet$ & & & & & & $\bullet$ \\
\hline & Immune surveillance parameters & $=$ & & O & & O & & & & & & $\bigcirc$ \\
\hline \multicolumn{13}{|l|}{$\begin{array}{l}\text { Cummings et al. (2011; } \\
120 \text { days) }\end{array}$} \\
\hline \multirow[t]{3}{*}{ Laternula elliptica (clam) } & Respiration & $\uparrow$ & & $\bullet$ & & & & & & & & \\
\hline & HSP70 expression & $\uparrow$ & & $\bullet$ & & & & & & & & \\
\hline & $\begin{array}{l}\text { Chitin synthase (CHS) } \\
\text { expression }\end{array}$ & $\uparrow$ & & $\bullet$ & & & & & & & & \\
\hline \multicolumn{13}{|l|}{$\begin{array}{l}\text { Dickinson et al. (2012; } \\
77 \text { days) }\end{array}$} \\
\hline \multirow{9}{*}{$\begin{array}{l}\text { Crassostrea virginica } \\
\text { (oyster) }\end{array}$} & Survival $_{\text {low salinity }}$ & $=$ & ○ & & & & & & & & & \\
\hline & Survival $_{\text {high salinity }}$ & $\downarrow$ & & & $\bullet$ & & & & & & & \\
\hline & Shell growth & $=$ & O & & $\bigcirc$ & & & & & & & \\
\hline & Tissue growth & $=$ & 0 & & O & & & & & & & \\
\hline & Shell resistance & $\downarrow$ & $\bullet$ & & $\bullet$ & & & & & & & \\
\hline & Enzymes activity & $=$ & O & & O & & & & & & & \\
\hline & Enzymes expression $_{\text {low salinity }}$ & $\downarrow$ & $\bullet$ & & & & & & & & & \\
\hline & Enzymes expression $_{\text {high salinity }}$ & $=$ & & & O & & & & & & & \\
\hline & Tissue metabolites & $\uparrow=\downarrow$ & $\bullet$ & & $\bullet$ & & & & & & & \\
\hline $\begin{array}{l}\text { Fernández-Reiriz et al. (2011 } \\
87 \text { days) }\end{array}$ & & & & & & & & & & & & \\
\hline Ruditapes philippinarum & Clearance & $\downarrow$ & & & & $\bullet$ & & & $\bullet$ & & & \\
\hline & Ingestion & $\downarrow$ & & & & $\bullet$ & & & 0 & & & \\
\hline & Respiration & $\downarrow$ & & & & $\bullet$ & & & $\bullet$ & & & \\
\hline & Excretion & $\uparrow$ & & & & $\bullet$ & & & $\bullet$ & & & \\
\hline $\begin{array}{l}\text { Fernández-Reiriz et al. (2012 } \\
78 \text { days) }\end{array}$ & & & & & & & & & & & & \\
\hline
\end{tabular}


Table 1 continued

\begin{tabular}{|c|c|c|c|c|c|c|c|c|c|c|c|c|}
\hline \multicolumn{3}{|l|}{ Adults and juveniles } & \multicolumn{10}{|c|}{$\mathrm{pH}$ (unit decrease from ambient) } \\
\hline \multirow{2}{*}{$\begin{array}{l}\text { Author/acclimation time } \\
\text { Species }\end{array}$} & \multirow[t]{2}{*}{ Process-impact } & & \multicolumn{4}{|c|}{ Projected 2100} & \multicolumn{6}{|c|}{ Projected 2300} \\
\hline & & & -0.1 & -0.2 & -0.3 & -0.4 & -0.5 & -0.6 & -0.7 & -0.8 & -0.9 & $>-1.0$ \\
\hline \multirow{6}{*}{$\begin{array}{l}\text { Mytilus galloprovincialis } \\
\text { (mussel) }\end{array}$} & Somatic growth & $\uparrow$ & & & O & & & $\bullet$ & & & & \\
\hline & Excretion & $\uparrow$ & & & 0 & & & - & & & & \\
\hline & Absorption efficiency & $\uparrow$ & & & $\bigcirc$ & & & $\bullet$ & & & & \\
\hline & Clearance & $=$ & & & O & & & $\bigcirc$ & & & & \\
\hline & Ingestion & $=$ & & & 0 & & & 0 & & & & \\
\hline & Respiration & $=$ & & & O & & & O & & & & \\
\hline \multicolumn{13}{|l|}{ Gazeau et al. (2007; 2 h) } \\
\hline Mytilus edulis (mussel) & Calcification & $\downarrow$ & & $\bullet$ & & & & & & & & \\
\hline Crassostrea gigas (oyster) & Calcification & $\downarrow$ & & $\bullet$ & & & & & & & & \\
\hline \multicolumn{13}{|l|}{ Green et al. (2009; 14 days) } \\
\hline $\begin{array}{l}\text { Mercenaria mercenaria } \\
\text { (clam) }\end{array}$ & Survival & $\downarrow$ & & & & & & ○ & & & ○ & \\
\hline \multicolumn{13}{|l|}{ Hale et al. (2011; 30 days) } \\
\hline Community & Structure & $\downarrow$ & & & $\bullet$ & & & & - & & & - \\
\hline \multicolumn{13}{|l|}{ Hammer et al. (2011; 4 days) } \\
\hline \multirow[t]{4}{*}{ Acesta excavata (clam) } & Respiration & & & & & & & & & & & O \\
\hline & Excretion & & & & & & & & & & & O \\
\hline & $\mathrm{pH}_{\mathrm{e}}$ level & & & & & & & & & & & $\bullet$ \\
\hline & $\mathrm{pH}_{\mathrm{i}}$ level & & & & & & & & & & & $\bullet$ \\
\hline \multicolumn{13}{|l|}{$\begin{array}{l}\text { Hiebenthal et al. (2012; } \\
90 \text { days) }\end{array}$} \\
\hline \multirow[t]{6}{*}{ Mytilus edulis (mussel) } & Shell growth & $=$ & $\bigcirc$ & $\bigcirc$ & & & & & & & & \\
\hline & Shell growth $25{ }^{\circ} \mathrm{C}$ & $\downarrow$ & O & $\bullet$ & & & & & & & & \\
\hline & Survival & $=$ & O & O & & & & & & & & \\
\hline & Shell breaking force & $=$ & ○ & $\bigcirc$ & & & & & & & & \\
\hline & Cellular stress & $=$ & O & O & & & & & & & & \\
\hline & Condition index & $\uparrow$ & - & O & & & & & & & & \\
\hline \multirow[t]{6}{*}{ Arctica islandica (clam) } & Shell growth & $=$ & O & O & & & & & & & & \\
\hline & Survival & $=$ & O & ○ & & & & & & & & \\
\hline & Shell breaking force & $=$ & $\bigcirc$ & O & & & & & & & & \\
\hline & Cellular stress & $\uparrow$ & O & - & & & & & & & & \\
\hline & Cellular stress $25{ }^{\circ} \mathrm{C}$ & $\uparrow$ & O & $\bullet$ & & & & & & & & \\
\hline & Condition index & $=$ & ○ & O & & & & & & & & \\
\hline \multicolumn{13}{|l|}{ Hüning et al. (2012; 60 days) } \\
\hline \multirow[t]{4}{*}{ Mytilus edulis (mussel) } & $\begin{array}{l}\text { Gene expression-energy/ } \\
\text { protein metabolism }\end{array}$ & $\downarrow$ & & & & ○ & & & & & ○ & O \\
\hline & Gene expression-chitinase & $\downarrow$ & & & & O & & & & & $\bigcirc$ & $\bullet$ \\
\hline & $\begin{array}{l}\text { Gene expression-matrix } \\
\text { proteins }\end{array}$ & $=$ & & & & O & & & & & $\bigcirc$ & $\bigcirc$ \\
\hline & Gene expression-tyrosinase & $\uparrow$ & & & & O & & & & & ○ & $\bullet$ \\
\hline \multicolumn{13}{|l|}{ Lannig et al. (2010; 55 days) } \\
\hline \multirow[t]{8}{*}{ Crassostrea gigas (oyster) } & $\mathrm{pH}_{\mathrm{e}}$ level & $\downarrow$ & & & & - & & & & & & \\
\hline & $P_{\mathrm{e}} \mathrm{CO}_{2}$ level & $\uparrow$ & & & & $\bullet$ & & & & & & \\
\hline & $P_{\mathrm{e}} \mathrm{O}_{2}$ level & $=$ & & & & $\bullet$ & & & & & & \\
\hline & $\mathrm{C}_{\mathrm{e}} \mathrm{CO}_{2}$ level & $\uparrow$ & & & & $\bullet$ & & & & & & \\
\hline & $\mathrm{HCO}_{3}^{-}$level & $\uparrow$ & & & & $\bullet$ & & & & & & \\
\hline & $\mathrm{Ca}^{2+}$ level & $=$ & & & & 0 & & & & & & \\
\hline & $\mathrm{Na}^{+}$level & $\downarrow$ & & & & $\bullet$ & & & & & & \\
\hline & $\mathrm{K}^{+}$level & $\uparrow$ & & & & $\bullet$ & & & & & & \\
\hline
\end{tabular}


Table 1 continued

\begin{tabular}{|c|c|c|c|c|c|c|c|c|c|c|c|c|}
\hline \multicolumn{3}{|l|}{ Adults and juveniles } & \multicolumn{10}{|c|}{$\mathrm{pH}$ (unit decrease from ambient) } \\
\hline \multirow{4}{*}{$\begin{array}{l}\text { Author/acclimation time } \\
\text { Species }\end{array}$} & \multirow[t]{2}{*}{ Process-impact } & & \multicolumn{4}{|c|}{ Projected 2100} & \multicolumn{6}{|c|}{ Projected 2300} \\
\hline & & & -0.1 & -0.2 & -0.3 & -0.4 & -0.5 & -0.6 & -0.7 & -0.8 & -0.9 & $>-1.0$ \\
\hline & Tissue metabolite levels & $\downarrow$ & & & & $\bullet$ & & & & & & \\
\hline & Respiration & $=$ & & & & $\bigcirc$ & & & & & & \\
\hline \multicolumn{13}{|l|}{ Liu and $\mathrm{He}$ (2012; 5 days) } \\
\hline \multirow[t]{3}{*}{ Pinctada fucata (oyster) } & Clearance & $\uparrow$ & & & & - & & & $\bullet$ & & & \\
\hline & Excretion & $=$ & & & & O & & & O & & & \\
\hline & Respiration & $=$ & & & & O & & & O & & & \\
\hline \multirow[t]{3}{*}{ Chlamys nobilis (clam) } & Clearance & $\downarrow$ & & & & $\bullet$ & & & $\bullet$ & & & \\
\hline & Excretion & $\downarrow$ & & & & $\bigcirc$ & & & $\bullet$ & & & \\
\hline & Respiration & $\downarrow$ & & & & $\bigcirc$ & & & $\bullet$ & & & \\
\hline \multirow[t]{3}{*}{ Perna viridis (mussel) } & Clearance & $\downarrow$ & & & & $\bullet$ & & & ○ & & & \\
\hline & Excretion & $=$ & & & & ○ & & & ○ & & & \\
\hline & Respiration & $=$ & & & & O & & & O & & & \\
\hline \multicolumn{13}{|l|}{ Lopez et al. (2010; 28 days) } \\
\hline $\begin{array}{l}\text { Ruditapes philippinarum } \\
\text { (clam) }\end{array}$ & Metal uptake & $\uparrow$ & & & & & & & & & & - \\
\hline \multicolumn{13}{|l|}{ Matozzo et al. (2012; 7 days) } \\
\hline Chamelea gallina (clam) & Immune system & $\downarrow$ & & & & - & & & $\bullet$ & & & \\
\hline $\begin{array}{l}\text { Mytilus galloprovincialis } \\
\text { (mussel) }\end{array}$ & Immune system & $\downarrow$ & & & & $\bullet$ & & & $\bullet$ & & & \\
\hline \multicolumn{13}{|l|}{$\begin{array}{l}\text { McClintock et al. (2009; } \\
28 \text { days) }\end{array}$} \\
\hline Laternula elliptica (clam) & Shell dissolution & $\uparrow$ & & & & & & & & - & & \\
\hline Yoldia eightsi (clam) & Shell dissolution & $\uparrow$ & & & & & & & & - & & \\
\hline \multicolumn{13}{|l|}{$\begin{array}{l}\text { Melzner et al. (2011; } \\
49 \text { days) }\end{array}$} \\
\hline \multirow[t]{3}{*}{ Mytilus edulis (mussel) } & Shell growth & $\downarrow$ & & & O & & & $\bigcirc$ & & $\bullet$ & & \\
\hline & Shell dissolution & $\uparrow$ & & & O & & & O & & $\bullet$ & & \\
\hline & Somatic growth & $=$ & & & $\bigcirc$ & & & $\bigcirc$ & & O & & \\
\hline \multicolumn{13}{|l|}{$\begin{array}{l}\text { Michaelidis et al. (2005; } \\
90 \text { days) }\end{array}$} \\
\hline \multirow{7}{*}{$\begin{array}{l}\text { Mytilus galloprovincialis } \\
\text { (mussel) }\end{array}$} & Shell growth & $\downarrow$ & & & & & & & $\bullet$ & & & \\
\hline & Respiration & $\downarrow$ & & & & & & & $\bullet$ & & & \\
\hline & Excretion & $\uparrow$ & & & & & & & $\bullet$ & & & \\
\hline & $\mathrm{pH}_{\mathrm{e}}$ level & $\downarrow$ & & & & & & & $\bullet$ & & & \\
\hline & Protein degradation & $\uparrow$ & & & & & & & $\bullet$ & & & \\
\hline & $\mathrm{HCO}_{3}^{-}$level & $\uparrow$ & & & & & & & $\bullet$ & & & \\
\hline & $\mathrm{Ca}^{2+}$ level & $\uparrow$ & & & & & & & - & & & \\
\hline \multicolumn{13}{|l|}{ Navarro et al. (2013; 70 days) } \\
\hline \multirow[t]{5}{*}{ Mytilus chilensis (mussel) } & Respiration & $\downarrow$ & O & $\bullet$ & & & & & & & & \\
\hline & Excretion & $=$ & O & O & & & & & & & & \\
\hline & Ingestion & $=$ & ○ & O & & & & & & & & \\
\hline & Clearance & $\downarrow$ & $\bigcirc$ & $\bullet$ & & & & & & & & \\
\hline & Adsorption & $\downarrow$ & O & - & & & & & & & & \\
\hline \multicolumn{13}{|l|}{ Parker et al. (2011; 4 days) } \\
\hline $\begin{array}{l}\text { Saccostrea glomerata } \\
\text { (oyster) }\end{array}$ & Shell growth & $\downarrow$ & & & & $\bullet$ & & & & & & \\
\hline Parker et al. (2012; 14 days) & & & & & & & & & & & & \\
\hline $\begin{array}{l}\text { Saccostrea glomerata } \\
\text { (oyster) }\end{array}$ & Respiration & $\uparrow$ & & & $\bullet$ & & & & & & & \\
\hline
\end{tabular}


Table 1 continued

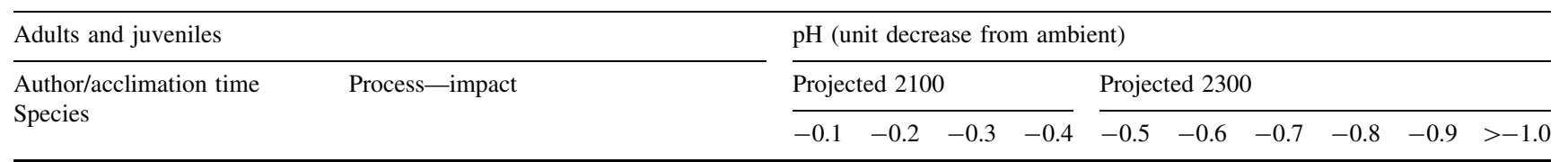

Range et al. (2011; 75 days)

Ruditapes decussatus (clam)

Shell growth
Tissue growth

Survival

Range et al. (2012; 84 days)

Mytilus galloprovincialis (mussel)

Ries et al. (2009; 60 days)

Mytilus edulis (mussel)

Mercenaria mercenaria

(hard clam)

Argopecten irradians

(scallop)

Crassostrea virginica

(oyster)

Mya arenaria (soft clam)

Schalkhausser et al. (2012; 30 days)

Pecten maximus (scallop)

Talmage and Gobler (2011;

\section{5 days)}

$\begin{aligned} & \text { Mercenaria mercenaria } \\ & \text { (clam) }\end{aligned}$
Argopecten irradians
(scallop)

Crassostrea virginica

(oyster)

Thomsen and Melzner (2010;

60 days)

Mytilus edulis (mussel)

Thomsen et al. (2010;

15-60 days)

Mytilus edulis (mussel)
Survival

Shell growth

Tissue growth

Calcification

Calcification

Calcification

Calcification

Calcification

Survival $_{4}{ }^{\circ} \mathrm{C}$

Survival $_{10}{ }^{\circ} \mathrm{C}$

$\mathrm{P}_{\mathrm{e}} \mathrm{CO}_{2}$

$\mathbf{p H}_{\mathbf{e}}$

$\left[\mathrm{HCO}_{3}^{-}\right]_{\mathrm{e}}$

Resting respiration

Maximal respiration

Clapping activity

Clapping force

Shell growth

Tissue growth

Shell growth

Tissue growth

Survival

Shell growth

Tissue growth

Shell growth

Somatic growth

Respiration

Excretion

Shell growth
$=$

$=$

$=$

$\uparrow$

$=$

$\downarrow$

$=$

$=$

$\downarrow$

$\bigcirc$

O

$\downarrow \quad \bigcirc$

$\downarrow \quad \bigcirc$

西

$=$

$\uparrow$

$\downarrow$

$\uparrow$

$=$

$\downarrow$

$=$

$\downarrow$

$=$

$=$

$=$

$=$

$\downarrow$

$\downarrow$

$=$

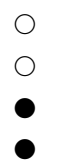

O

O

○

$\bigcirc$

-

○

$\bigcirc$ 
Table 1 continued

\begin{tabular}{|c|c|c|c|c|c|c|c|c|c|c|c|c|}
\hline \multicolumn{3}{|l|}{ Adults and juveniles } & \multicolumn{10}{|c|}{$\mathrm{pH}$ (unit decrease from ambient) } \\
\hline \multirow{2}{*}{$\begin{array}{l}\text { Author/acclimation time } \\
\text { Species }\end{array}$} & \multirow[t]{2}{*}{ Process_impact } & & \multicolumn{4}{|c|}{ Projected 2100} & \multicolumn{6}{|c|}{ Projected 2300} \\
\hline & & & -0.1 & -0.2 & -0.3 & -0.4 & -0.5 & -0.6 & -0.7 & -0.8 & -0.9 & $>-1.0$ \\
\hline & Tissue growth & $=$ & & & & $\bigcirc$ & & & & & $\bigcirc$ & $\bigcirc$ \\
\hline & $\mathrm{pH}_{\mathrm{e}}$ level & $\downarrow$ & $\bigcirc$ & $\bigcirc$ & O & & $\bullet$ & & & & & $\bullet$ \\
\hline & $\mathrm{P}_{\mathrm{e}} \mathrm{CO}_{3}{ }^{2-}$ level & $\downarrow$ & $\bigcirc$ & $\bigcirc$ & $\bigcirc$ & & - & & & & & ○ \\
\hline & $P_{\mathrm{e}} \mathrm{CO}_{2}$ level & $\uparrow$ & $\bigcirc$ & $\bigcirc$ & $\bigcirc$ & & $\bigcirc$ & & & & & $\bullet$ \\
\hline & $\mathrm{HCO}_{3}^{-}$level & $=$ & 0 & $\bigcirc$ & $\mathrm{O}$ & & $\bigcirc$ & & & & & $\bigcirc$ \\
\hline & $\mathrm{Ca}^{2+}$ level & $=$ & $\bigcirc$ & $\bigcirc$ & $\bigcirc$ & & $\bigcirc$ & & & & & $\bigcirc$ \\
\hline & $\mathrm{Na}^{2+}$ level & $\uparrow$ & $\bigcirc$ & $\bigcirc$ & $\bigcirc$ & & $\bigcirc$ & & & & & - \\
\hline & $\mathrm{K}^{+}$level & $=$ & $\bigcirc$ & $\bigcirc$ & $\bigcirc$ & & $\bigcirc$ & & & & & $\bigcirc$ \\
\hline & $\mathrm{Mg}^{2+}$ level & $=$ & $\bigcirc$ & $\bigcirc$ & $\bigcirc$ & & $\bigcirc$ & & & & & $\bigcirc$ \\
\hline \multicolumn{13}{|l|}{$\begin{array}{l}\text { Tomanek et al. (2011; } \\
14 \text { days) }\end{array}$} \\
\hline \multirow[t]{2}{*}{ Crassostrea gigas (oyster) } & Cytoskeleton proteins & $\uparrow$ & & & & & & & & - & & \\
\hline & Oxidative stress & $\uparrow$ & & & & & & & & - & & \\
\hline \multicolumn{13}{|l|}{ Waldbusser et al. (2010; 8 h) } \\
\hline $\begin{array}{l}\text { Mercenaria mercenaria } \\
\text { (clam) }\end{array}$ & Calcification & $\downarrow$ & & & & - & & $\bullet$ & & & & \\
\hline \multicolumn{13}{|l|}{$\begin{array}{l}\text { Waldbusser et al. (2011b; } \\
\mathbf{1 5} \text { h) }\end{array}$} \\
\hline $\begin{array}{l}\text { Crassostrea virginica } \\
\text { (oyster) }\end{array}$ & Calcification & $\downarrow$ & & $\bullet$ & $\bullet$ & $\bullet$ & $\bullet$ & $\bullet$ & ○ & & & \\
\hline \multicolumn{13}{|l|}{$\begin{array}{l}\text { Waldbusser et al. (2011a; } \\
14 \text { days) }\end{array}$} \\
\hline $\begin{array}{l}\text { Crassostrea virginica } \\
\text { (oyster) }\end{array}$ & Shell dissolution & $\uparrow$ & & • & & & - & & ○ & & & \\
\hline \multicolumn{13}{|l|}{$\begin{array}{l}\text { Watson et al. (2012b; } \\
\text { 60 days) }\end{array}$} \\
\hline Tridacna squamosa (clam) & Survival & $\downarrow$ & - & & - & & & & & & & \\
\hline \multicolumn{13}{|l|}{$\begin{array}{l}\text { Welladsen et al. (2010; } \\
28 \text { days) }\end{array}$} \\
\hline \multirow[t]{3}{*}{ Pinctada fucata (oyster) } & Shell strength & $\downarrow$ & & & $\bullet$ & & - & & & & & \\
\hline & Shell organic content & $=$ & & & $\bigcirc$ & & $\bigcirc$ & & & & & \\
\hline & Shell dissolution & $\uparrow$ & & & $\bigcirc$ & & - & & & & & \\
\hline \multicolumn{13}{|l|}{ Gastropods } \\
\hline \multicolumn{13}{|l|}{ Bibby et al. (2007; 15 days) } \\
\hline \multirow{3}{*}{$\begin{array}{l}\text { Littorina littorea } \\
\text { (periwinkle) }\end{array}$} & Shell thickness & $\downarrow$ & & & & & & & & & & ○ \\
\hline & Respiration & $\downarrow$ & & & & & & & & & & $\bullet$ \\
\hline & Behaviour & $\uparrow$ & & & & & & & & & & $\bullet$ \\
\hline \multicolumn{13}{|l|}{ Marchant et al. (2010; 5 days) } \\
\hline \multirow[t]{9}{*}{ Patella vulgata (limpet) } & Respiration & $=$ & & & & & & $\bigcirc$ & & & & \\
\hline & Protein content & $=$ & & & & & & $\bigcirc$ & & & & \\
\hline & Feeding rate & $=$ & & & & & & $\bigcirc$ & & & & \\
\hline & Radula structure & $\downarrow$ & & & & & & $\bullet$ & & & & \\
\hline & $\mathrm{pH}_{\mathrm{e}}$ level & $=$ & & & & & & $\bigcirc$ & & & & \\
\hline & $P_{\mathrm{e}} \mathrm{CO}_{2}$ level & $\uparrow$ & & & & & & $\bullet$ & & & & \\
\hline & $\mathrm{HCO}_{3}^{-}$level & $\uparrow$ & & & & & & - & & & & \\
\hline & $\mathrm{Ca}^{2+}$ level & $\uparrow$ & & & & & & $\bullet$ & & & & \\
\hline & $\mathrm{Mg}^{2+}$ level & $=$ & & & & & & O & & & & \\
\hline $\begin{array}{l}\text { McClintock et al. (2009; } \\
28 \text { days) }\end{array}$ & & & & & & & & & & & & \\
\hline
\end{tabular}


Table 1 continued

\begin{tabular}{|c|c|c|c|c|c|c|c|c|c|c|c|c|}
\hline \multicolumn{3}{|l|}{ Adults and juveniles } & \multicolumn{10}{|c|}{ pH (unit decrease from ambient) } \\
\hline \multirow{2}{*}{$\begin{array}{l}\text { Author/acclimation time } \\
\text { Species }\end{array}$} & \multirow[t]{2}{*}{ Process-impact } & & \multicolumn{4}{|c|}{ Projected 2100} & \multicolumn{6}{|c|}{ Projected 2300} \\
\hline & & & -0.1 & -0.2 & -0.3 & -0.4 & -0.5 & -0.6 & -0.7 & -0.8 & -0.9 & $>-1.0$ \\
\hline Nacella concinna (limpet) & Shell dissolution & $\uparrow$ & & & & & & & & $\bullet$ & & \\
\hline \multicolumn{13}{|l|}{ Nienhuis et al. (2010; 6 days) } \\
\hline \multirow[t]{2}{*}{ Nucella lamellosa (snail) } & Shell growth & $\downarrow$ & & ○ & & - & & & & & & \\
\hline & Shell dissolution & $\uparrow$ & & $\bullet$ & & ○ & & & & & & \\
\hline \multicolumn{13}{|l|}{ Ries et al. (2009; 60 days) } \\
\hline Crepidula fornicata (limpet) & Calcification & $\uparrow$ & $\bigcirc$ & 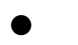 & & & & & $\bigcirc$ & & & \\
\hline Strombus alatus (conch) & Calcification & $\downarrow$ & ○ & O & & & & & $\bullet$ & & & \\
\hline $\begin{array}{l}\text { Littorina littorea } \\
\text { (periwinkle) }\end{array}$ & Calcification & $\downarrow$ & $\bigcirc$ & $\bullet$ & & & & & $\bullet$ & & & \\
\hline Urosalpinx cinerea (whelk) & Calcification & $\downarrow$ & $\bullet$ & 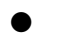 & & & & & 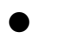 & & & \\
\hline \multicolumn{13}{|l|}{$\begin{array}{l}\text { Shirayama and Thornton } \\
(2005 ; 180 \text { days })\end{array}$} \\
\hline \multirow[t]{3}{*}{ Strombus lubuanus (snail) } & Survival & $\downarrow$ & ○ & & & & & & & & & \\
\hline & Shell growth & $\downarrow$ & - & & & & & & & & & \\
\hline & Shell weight & $\downarrow$ & 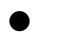 & & & & & & & & & \\
\hline
\end{tabular}

In bold, studies considering more than one stressor (e.g. temperature, salinity, food availability, etc.). Open and full circles refer to not significant and significant effects, respectively

mussel Mytilus edulis, no effect of $\mathrm{pH}$ over the full range was found, but this could have been masked by the low growth and the large variability of the data. The limpet C. fornicata presented a bell-shaped response with maximal rates of shell growth at the intermediate $p \mathrm{CO}_{2}$ level (900 $\mu \mathrm{atm})$. The conch Strombus alatus, the bay scallop Argopecten irradians and the hard clam Mercenaria mercenaria showed no effects of $\mathrm{pH}$ within the range of projected values for the end of the century. Finally, the other four species (whelk: Urosalpinx cinerea, periwinkle: L. littorea, oyster: $C$. virginica and soft clam: Mya arenaria) showed significant decreases in shell growth with decreases in $\mathrm{pH}$ smaller than $-0.4 \mathrm{pH}$ unit. For all species except for the blue mussel and the limpet, significant decreases in shell growth were reported for the lowest $\mathrm{pH}$ level $(-0.7 \mathrm{pH}$ unit). Importantly, out of these nine species, five were unable to maintain positive net calcification rates under these corrosive conditions for aragonite. For the four other species (bay scallop, oyster, mussel, limpet), shell gross calcification may have been high enough to outcompete shell dissolution or shell dissolution may have been minimalized thanks to an efficient organic layer protecting the shell. As the shell of limpets is mostly composed of aragonite (more soluble than low-magnesium calcite) and not fully covered by a protective organic layer (periostracum), the reasons of the apparent resilience of this species to acidification are unclear. An additional factor to consider could be the range of $\mathrm{pH}$ at which the organisms are naturally exposed in the field (see thereafter).
Range et al. (2011) and Range et al. (2012) found no effects of decreased water $\mathrm{pH}$ levels (up to $-0.7 \mathrm{pH}$ unit) on shell length and weight after a 75-day exposure of juvenile clams (Ruditapes decussatus) and Mediterranean mussels. As stressed by the authors, the sea water used during this experiment and pumped from the Ria Formosa lagoon had high alkalinity levels of $>3,000 \mu \mathrm{mol} \mathrm{kg}{ }^{-1}$, which means that even under the most acidified conditions ( $-0.7 \mathrm{pH}$ unit), it was still oversaturated with respect to aragonite.

In a much less alkaline environment, Thomsen and Melzner (2010) observed, in contrast to Ries et al. (2009), significant linear decreases in both shell mass and shell length for blue mussels exposed to low $\mathrm{pH}$ conditions $(-0.3,-0.65$ and $-0.9 \mathrm{pH}$ unit) for a period of 2 months. As previously discussed for Ries et al. (2009), as the $\mathrm{pH}$ range goes well beyond the projection for the end of the century, data obtained for a $\mathrm{pH}$ decrease of -0.3 unit were treated separately from the other data and compared to control conditions by means of Student's $t$ tests. Although, as a consequence of low alkalinity levels, mussels were exposed to undersaturated sea water with respect to aragonite already following a $\mathrm{pH}$ decrease of -0.3 , no significant reduction in shell growth could be observed as compared to control conditions. This study therefore suggested that mussels are able to maintain calcification rates when exposed to slightly undersaturated conditions with respect to aragonite. Similarly, Thomsen et al. (2010), in accordance with Hiebenthal et al. (2012), showed no 
effects of a pH decrease of -0.4 on shell mass and extension rate of Mytilus edulis from Kiel Fjord also after 2-month exposure, although these organisms do not appear to regulate extracellular $\mathrm{pH}$ levels (14-day experiment at $p \mathrm{CO}_{2}$ levels of $\sim 460$ (control), 660, 790, 1,050, 1,500 and $4,250 \mu \mathrm{atm})$. Only at a very high $\mathrm{pCO}_{2}$ level of 4,000 $\mu \mathrm{atm}$ ( $-0.9 \mathrm{pH}$ unit; 2 months exposure) were the results by Thomsen et al. (2010) in accordance with those of Thomsen and Melzner (2010) showing a significant decrease in both shell mass and extension rates as compared to control conditions. Melzner et al. (2011) studied the synergistic effects of decreased $\mathrm{pH}(-0.3,-0.65$ and $-0.85 \mathrm{pH}$ unit) and food limitation on $M$. edulis during winter. Low food algae concentrations and high $p \mathrm{CO}_{2}$ values each significantly decreased shell length growth and influenced the magnitude of inner shell surface dissolution. However, the effects of $p \mathrm{CO}_{2}$ were only visible at very high levels, with no effect of a $\mathrm{pH}$ decrease of -0.3 and -0.6 on shell growth. Interestingly, internal shell surface corrosion was observed at the two highest $p \mathrm{CO}_{2}$ treatments in the high-food group, while it was found in all treatments in the low-food group. This suggests that well-fed healthy animals might display a higher capacity to compensate than starving individuals and that the physiological conditions of the specimens are essential (see section "Synergistic impacts").

In contrast to Ries et al. (2009) for the Eastern oyster C. virginica, Dickinson et al. (2012) showed that shell growth of juvenile oysters were not affected by a $\mathrm{pH}$ decrease of up to $-0.3 \mathrm{pH}$ unit. However, the mechanical properties of the shells of the juveniles were altered under hypercapnic conditions, resulting in a reduced hardness and fracture resistance. This confirmed the results of Beniash et al. (2010) and Welladsen et al. (2010) on oysters, showing that the ultrastructure and the mechanical properties of the shells were significantly altered under high $\mathrm{CO}_{2}$. Nienhuis et al. (2010) have shown that the growth of the rocky intertidal snail Nucella lamellosa decreases with increasing $p \mathrm{CO}_{2}$ levels as a consequence of increased dissolution rates. This suggests that gross calcification was not impacted. Unfortunately, the lack of information on the carbonate chemistry during the incubations does not allow the determination of whether the organisms were exposed to undersaturated conditions or not. In a study by McClintock et al. (2009), post-mortem exposures of two Antarctic bivalves and a limpet to lower pH levels $(-0.8$ $\mathrm{pH}$ unit; sea water undersaturated with respect to aragonite and calcite) for 28 days led to a marked increase in shell dissolution while there was no signs of dissolution in the control conditions (oversaturation with respect to calcite and aragonite; McClintock et al. 2009). In contrast, Waldbusser et al. (2011a) observed mass loss of Eastern oyster empty shells even under non-corrosive conditions, a process attributed to the presence of microbes on the shells and the secondary effects of metabolic $\mathrm{CO}_{2}$ production. These results demonstrate that a good understanding of the effects of ocean acidification on shell growth requires considering both shell deposition and dissolution.

Finally, in addition to the important variety of responses between species, Parker et al. (2011) showed that the response of wild oyster (Sydney rock oyster Saccostrea glomerata) spat to a decrease of $\mathrm{pH}(-0.4 \mathrm{pH}$ unit; 4-day exposure) was different from the response of spat from a selectively bred line. Indeed, the selectively bred population appeared more resistant than the wild population with a $25 \%$ reduction in shell growth at low $\mathrm{pH}$, compared with a $64 \%$ reduction in shell growth for the wild population at low $\mathrm{pH}$.

To summarize, 22 experiments (from 16 published papers) have focused on the effects of ocean acidification on shell growth and/or net calcification rates of shelled mollusc species (10 bivalves, 6 gastropod species) considering scenarios in $\mathrm{pH}$ decrease that are relevant for the present century $(<-0.4 \mathrm{pH}$ unit). These studies have been carried out on various time scales (from few hours to several months, see also section "Acclimation and adaptation potential"). Assessments of individual sensitivities should allow the organism to acclimate and reach its maximum capacity to compensate for the $\mathrm{CO}_{2}$ challenge. Studies on the time scale of hours (Gazeau et al. 2007; Waldbusser et al. 2010; Waldbusser et al. 2011b), therefore, may yield higher sensitivities than those carried out over days, weeks and months and have not been considered in Fig. 4. In the large majority of studies that have used $\mathrm{pH}$ reductions for the end of this century, there has been no effect of elevated $\mathrm{CO}_{2}$ on the shell growth of molluscs

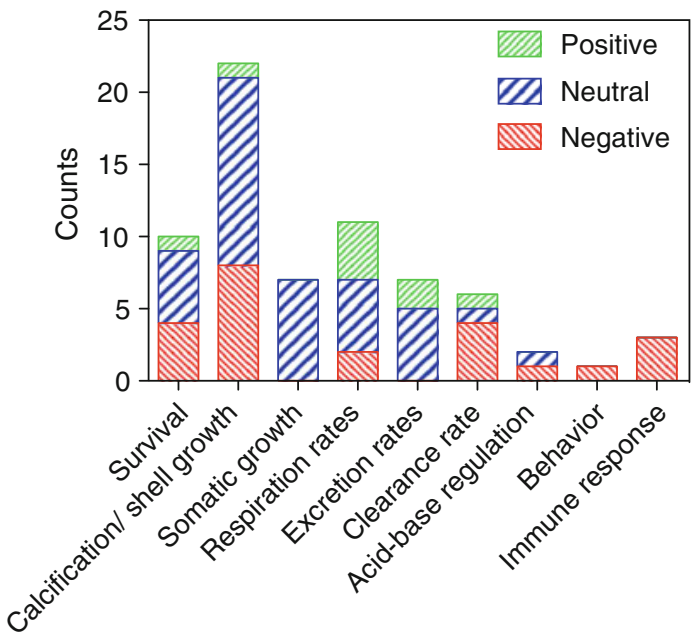

Fig. 4 Summary of the impacts of ocean acidification on juvenile and adult shelled molluscs for studies considering a $\mathrm{pH}$ decrease lower than 0.4 unit 
(13 out of 22; Fig. 4), while eight concluded on negative impacts and in only one case, the studied species (limpet, Ries et al. 2009) seemed to benefit from a decreased $\mathrm{pH}$ level. Therefore, it appears that the majority of the studied species have potentially the capacity to upregulate calcification rates under reduced $\mathrm{pH}$ and calcium carbonate saturation state levels. Mussels (Mediterranean and blue mussels) are the most studied species regarding shell growth with six datasets, all showing a good resilience of this species to $\mathrm{pH}$ levels projected for the end of the century. Oysters, the other economically very important group of species, appear less resistant than mussels to low $\mathrm{pH}$ conditions (three experiments showing negative impacts out of five), despite producing less soluble low-magnesium calcite shells. Moreover, the study showing no effect on oyster shell growth (Dickinson et al. 2012) demonstrated that a $\mathrm{pH}$ decrease of less than $-0.4 \mathrm{pH}$ unit had significant effects on the shell hardness and fracture resistance. This could have importance consequences for this species in the field with a reduced capacity to resist to, for instance, strong currents and predators.

Based on available data, it seems impossible to draw a general picture of the effects of ocean acidification on the calcification of shelled molluscs. As it has been discussed above, the causes of the observed variability of responses are multiple, including, as stated by Ries et al. (2009): (1) differential capacities of the organisms to regulate $\mathrm{pH}$ at the site of calcification, (2) the structure and composition of the protective organic layers that can vary widely among organisms and (3) the mineralogy of the shell with a theoretical higher vulnerability of organisms that secrete more soluble forms of calcium carbonate (aragonite and high magnesium calcite). Additionally, many marine shelled molluscs inhabit coastal areas where $\mathrm{pH}$ is already lower and much more variable than in the open ocean as a consequence of eutrophication and/or input of low $\mathrm{pH}$ water from rivers or upwelling. Many species are certainly already adapted to fluctuant and low $\mathrm{pH}$ conditions. However, all reviewed studies, with no exception, considered stable $\mathrm{pH}$ levels and a control level close to $\mathrm{pH} \sim 8$, which might not be representative of the coastal ocean. This will be further developed in section "Environmental conditions versus laboratory conditions".

Considering $\mathrm{pH}$ decreases larger than $-0.4 \mathrm{pH}$ unit, most of the studies have shown significant effects of this perturbation on shell growth of various species. Since the great majority of these studies have been conducted under corrosive conditions with respect to aragonite (and sometimes calcite, see supplementary Table), these undersaturated conditions might be responsible for the observed effects on shell growth rates. In high-alkalinity-level areas such as in the studies of Range et al. $(2011,2012)$, even a $\mathrm{pH}$ decrease of $-0.7 \mathrm{pH}$ unit did not lead to significant decreases in shell growth, sea water still being above the saturation level with respect to aragonite. The mechanisms setting the rate of net calcification (gross calcification minus dissolution) still remain to be explored. The correlation of calcification rate with $\Omega$ is species specific, making it impossible to quantify a uniform sensitivity threshold of $\Omega$ below which a net slowing of calcification sets in. While the organisms may have the capacity to upregulate gross calcification rates, shell dissolution may outcompete shell production, leading to a net decrease in shell weight (i.e. Nienhuis et al. 2010, Nucella lamellosa). It is, however, not clear to what extent shell growth is solely dependent on $\Omega$ or also related to changes in organismal metabolism under low $\mathrm{pH}$ conditions (Thomsen and Melzner 2010). Such effects of $\mathrm{pH}$ on other relevant physiological mechanisms of marine and estuarine shelled molluscs will be discussed in the following section. Finally, it must be stressed that shelled molluscs have colonized environments characterized by very corrosive conditions for both calcite and aragonite (e.g. Tunnicliffe et al. 2009), showing that under some circumstances, these species were able to adapt and develop mechanisms (including the production of a very strong shell protecting organic layer) in order to maintain positive net calcification. This will be further discussed in section "Field studies".

\section{Other physiological processes}

The effects of ocean acidification on the calcification and growth of mollusc shells have been widely recognized for some time. More recently, however, it has become apparent that ocean acidification may also impact on other fitnesssustaining processes through its effects on the acid-base status and energy budgets of marine organisms. As the concentration of $\mathrm{CO}_{2}$ in sea water increases, it enters the extra- and intracellular compartments of marine organisms (hypercapnia) by a process of diffusion. $\mathrm{CO}_{2}$ continues to rise in these compartments until a new steady-state gradient is reached, which is sufficient to allow $\mathrm{CO}_{2}$ excretion (Seibel and Walsh 2003). This rise in $\mathrm{CO}_{2}$ leads to a rise in $\mathrm{H}^{+}$ions and causes acidosis (reduction in $\mathrm{pH}$ ) of the internal body fluids (Pörtner et al. 2004; Wicks and Roberts 2012). Passive buffering using non-bicarbonate buffers is the mechanism immediately used by organisms to reduce the associated changes in $\mathrm{pH}$ (Seibel and Walsh 2003; Pörtner et al. 2004; Fabry et al. 2008), with $\mathrm{H}^{+}$ions becoming bound to non-bicarbonate buffers (Melzner et al. 2009). However, passive buffering only masks the effects of acidosis. In order for acid-base balance to be restored over longer more chronic $\mathrm{CO}_{2}$ exposure (hours to days), excess $\mathrm{H}^{+}$ions must be removed from the extra- and intracellular compartments (Melzner et al. 2009) using 
active ion-exchange mechanisms. These mechanisms actively transport acid-base relevant ions across cell and epithelial membranes, removing $\mathrm{H}^{+}$and accumulating $\mathrm{HCO}_{3}{ }^{-}$ions (Seibel and Walsh 2003; Pörtner et al. 2004; Fabry et al. 2008). Ion transport is primarily mediated by protein carriers including $\mathrm{Na}^{+} / \mathrm{K}^{+}$and $\mathrm{H}^{+}$ATPases (which exchange $\mathrm{Na}^{+} / \mathrm{H}^{+}$or $\mathrm{Cl}^{-} / \mathrm{HCO}_{3}{ }^{-}$; Pörtner et al. 2004; Fabry et al. 2008).

Typically, marine benthic shelled molluscs with slow or sessile modes of life and low metabolic rates have less developed ion-exchange and non-bicarbonate buffering mechanisms and generally lack a true ion-regulatory organ (Melzner et al. 2009). As a result, their capacity to compensate for changes in acid-base status due to elevated $\mathrm{CO}_{2}$ is somewhat limited (Melzner et al. 2009). While compensation of intracellular $\mathrm{pH}$ is thought to occur quite rapidly (within 24-72 h) due to lower starting $\mathrm{pH}$ values (0.5-0.8 unit lower than extracellular $\mathrm{pH})$ and greater accumulation of $\mathrm{HCO}_{3}{ }^{-}$, this is often at the expense of extracellular pH (Pörtner et al. 2004). Uncompensated extracellular $\mathrm{pH}$ may cause changes in the metabolic rate of shelled mollusc species and mediate unfavourable "trade-offs" in their energy budget. For example, a greater proportion of energy may be partitioned towards the maintenance of acid-base status and away from other critical fitness-sustaining processes such as shell and somatic growth, immune response, protein synthesis, behaviour and reproduction. To date, no studies have assessed the full energy budget response of shelled molluscs during exposure to elevated $\mathrm{CO}_{2}$ (Wicks and Roberts 2012); however, effects on single energy budget parameters suggest that a variety of processes will be negatively affected.

During acute hypercapnia, metabolic depression is an adaptive mechanism used by shelled molluscs to conserve energy, for example, during air exposure of intertidal ectotherms or other situations of extreme oxygen deficiency or internal $\mathrm{CO}_{2}$ accumulation (Pörtner et al. 2004). This adaptive mechanism is time-limited, however, and following longer more chronic episodes of hypercapnia, metabolic depression can become lethal. Shelled mollusc species that are pre-adapted to life in the intertidal and regularly experience associated oscillations in body fluid $p \mathrm{CO}_{2}$ between tidal cycles may more readily exploit metabolic depression to save energy in response to ocean acidification. Such a response was seen in the intertidal mussel M. galloprovincialis (Michaelidis et al. 2005) as well as in the clams $R$. decussatus (Fernández-Reiriz et al. 2011) and Chlamys nobilis (Liu and He 2012) following exposure to elevated $\mathrm{CO}_{2}$. As already mentioned, Michaelidis et al. (2005) exposed adults and juveniles of the mussel $M$. galloprovincialis to a decrease in $\mathrm{pH}$ of -0.75 $\mathrm{pH}$ unit. During the exposure, the mussel accumulated
$\mathrm{HCO}_{3}{ }^{-}$, derived partially from the dissolution of its shell, but was unable to compensate for extracellular acidosis. As a result, there was a reduction in the standard metabolic rate (SMR) of the mussels as well as a net degradation of proteins. Reduced SMR and protein degradation were also found in juveniles of the clam $R$. decussatus exposed to a 0.4 pH unit reduction for 87 days (Fernández-Reiriz et al. 2011). In addition, the clams also showed a reduction in clearance rate, suggesting that energy intake was significantly reduced. Such effects will undoubtedly have negative impacts on shelled molluscs. Degradation of proteins and reduced energy input seen in M. galloprovincialis and $R$. decussatus as well as other shelled mollusc species (M. edulis, Thomsen and Melzner 2010; M. galloprovincialis, Fernández-Reiriz et al. 2012) following ocean acidification stress will impact on processes such as somatic growth (Fernández-Reiriz et al. 2011) and reproduction (no studies to date). In contrast to the intertidal and subtidal species described above, exposure of the deep-sea clam Acesra excavata to extremely high levels of $\mathrm{CO}_{2}(2,600-33,000 \mu \mathrm{atm})$ led to a decrease in SMR at the beginning of the exposure, but a return of SMR to control levels by the end of the exposure (Hammer et al. 2011). Deep-sea shelled molluscs are predicted to be highly sensitive to elevated $\mathrm{CO}_{2}$. The results of this study, however, suggest that the deep-sea clam may have a greater capacity to compensate for $\mathrm{CO}_{2}$-induced changes in acid-base status than previously thought.

As shown above, only 2 studies considering realistic $\mathrm{pH}$ scenarios (offset $<-0.4 \mathrm{pH}$ unit) reported on a decrease in SMR for shelled molluscs (Fernández-Reiriz et al. 2011; Navarro et al. 2013; see Fig. 4) while four experiments concluded on an increase in their SMR during exposure to elevated $\mathrm{CO}_{2}$ (Lannig et al. 2010; Thomsen and Melzner 2010; Cummings et al. 2011; Parker et al. 2012), suggesting an ability to at least partially compensate for the increased energy costs of acidosis (Wicks and Roberts 2012). In the mussel M. edulis, for example, exposure to elevated $\mathrm{CO}_{2}$ of $1,120 \mu \mathrm{atm}(-0.3 \mathrm{pH}$ unit) for 60 days led to a significant increase in SMR (Thomsen and Melzner 2010). In juveniles of the oyster $C$. virginica, exposure to elevated $\mathrm{CO}_{2}$ of $\sim 3,300 \mu \mathrm{atm}(-0.7 \mathrm{pH}$ unit $)$ for 20 weeks, a level much higher than that used in the previous study (and therefore not shown in Fig. 4), caused an increase in SMR which was accompanied by a decrease in both shell and somatic growth and survival (Beniash et al. 2010). A number of other shelled mollusc species have also suffered reduced survival following chronic exposure to elevated $\mathrm{CO}_{2}$ (snail S. lubuanus, Shirayama and Thornton 2005; mussel M. edulis, Berge et al. 2006; clam M. mercenaria, Green et al. 2009; oyster $C$. virginica, Dickinson et al. 2012; clam T. squamosa, Watson et al. 2012b).

In the oyster $C$. gigas, exposure to elevated $\mathrm{CO}_{2}$ of $1,500 \mu \mathrm{atm}(-0.4 \mathrm{pH}$ unit) for 55 days had no effect on 
SMR at ambient temperature, but caused a significant increase in SMR at elevated temperature $\left(+5{ }^{\circ} \mathrm{C}\right.$; Lannig et al. 2010). This suggests that the permanent reduction in $\mathrm{pHe}(-0.5 \mathrm{pHe}$ unit below control) caused no elevations in whole organism energy demand in the $\mathrm{CO}_{2}$-exposed animals when reared at their optimal temperature, but an elevation in energy demand in $\mathrm{CO}_{2}$-exposed animals when reared at elevated temperature (Lannig et al. 2010). This may indicate enhanced sensitivity to temperature at elevated $p \mathrm{CO}_{2}$, in similar ways as seen in crustaceans (Metzger et al. 2007; Walther et al. 2009). As a general principle, the thermal windows of marine ectotherms, which shape their range of biographical distribution, are likely to narrow under ocean acidification (Pörtner and Farrell 2008). Nevertheless, it has to be stressed that the majority of the experiments showed that $\mathrm{pH}$ within the range projected for the century has no effect on respiration rates of shelled molluscs (Lannig et al. 2010; FernandezReiriz et al. 2012; Liu and He 2012; Schalkhausser et al. 2012)

It has been suggested that organisms with naturally high metabolic rates, for example teleosts fish, brachyuran crustaceans and cephalopod molluscs, will be less sensitive to ocean acidification stress (Melzner et al. 2009). But differences in metabolic rate between benthic shelled mollusc species may also be an indicator of sensitivity and resilience. Parker et al. (2012), for example, measured the standard metabolic rate of wild population and selectively bred $\mathrm{CO}_{2}$-resilient population of the Sydney rock oyster, S. glomerata, following a 5-week exposure to elevated $\mathrm{CO}_{2}$ ( $\sim 860 \mu \mathrm{atm})$. They found that while both oyster populations increased their SMR following exposure to elevated $\mathrm{CO}_{2}$, the starting SMR of the $\mathrm{CO}_{2}$-resilient population was significantly higher than that of the wild population. The SMR of shelled mollusc species may an important determinant of species sensitivity to ocean acidification stress.

In the limpet Patella vulgata (Marchant et al. 2010), mussels Perna viridis (Liu and He 2012) and M. galloprovincialis (Fernandez-Reiriz et al. 2012) and oyster Pinctada fucata (Liu and He 2012), there was no observable change in SMR during exposure to elevated $\mathrm{CO}_{2}$ (see Fig. 4). Trade-offs in energy allocation may still exist, however, such that metabolic stimulation occurs in one tissue whereas metabolic depression occurs in another (Lannig et al. 2010). Marchant et al. (2010) exposed the limpet $P$. vulgata to a 0.6 -unit reduction in $\mathrm{pH}$ (therefore this study was not considered in Fig. 4) and found no change in SMR together with a completely compensated pHe compared with the controls. Like a number of shelled mollusc species, however, compensation of $\mathrm{pHe}$ occurred from the accumulation of $\mathrm{HCO}_{3}{ }^{-}$, derived primarily from shell dissolution, as evidenced by an increase in extracellular $\left[\mathrm{Ca}^{2+}\right]$. In contrast, in the mussel M. galloprovincialis, exposure to moderately elevated $\mathrm{CO}_{2}$ (-0.3-unit $\mathrm{pH}$ reduction) had no effect on the SMR, somatic growth, clearance, ingestion and excretion rates (Fernandez-Reiriz et al. 2012). While other processes such as shell growth, acid-base status and immune response were not investigated, this species seems somewhat resilient to moderate elevations in $p \mathrm{CO}_{2}$ (but see Michaelidis et al. 2005 earlier in this section for lower $\mathrm{pH}$ conditions).

Despite being crucial physiological traits for ecological success, very little is known of the effects of ocean acidification on shelled mollusc health and the potential for shelled mollusc species to resist predators and/or disease. Bibby et al. (2008) showed an effect of acidification $(-0.2$ to $-1.1 \mathrm{pH}$ unit) on the immune response of the blue mussel (M. edulis). Conditions of the carbonate chemistry are presented in supplementary Table 1 and were computed based on reported $\mathrm{pH}$ and $\mathrm{pCO}_{2}$ levels. Surprisingly, based on these values, $\mathrm{TCO}_{2}$ concentrations did not increase with decreasing $\mathrm{pH}$ levels (and the addition of $\mathrm{CO}_{2}$ ) and the alkalinity level was very low at the lowest $\mathrm{pH}$ condition, altogether raising some doubts about the reliability of reported $\mathrm{pH}$ and/or $p \mathrm{CO}_{2}$ conditions or suggesting the effects of processes other than calcification/ dissolution on the variation of $\mathrm{TCO}_{2}$ in the experimental tanks. As stated by the authors, the predominant mechanism of internal defence in bivalves involves phagocytosis by circulating haemocytes. While levels of phagocytosis increased during exposure under control conditions, suggesting an immune response induced by the experimental set-up, phagocytosis strongly declined as a function of decreasing $\mathrm{pH}$ levels. While phagocytotic activity as a health indicator of these organisms was statistically altered at low $\mathrm{pH}$ levels, no impact has been shown on tissue structure. As the concentration of intracellular $\mathrm{Ca}^{2+}$ is thought to play a role in haemocyte phagocytosis, the decreased immune responses observed at low $\mathrm{pH}$ were attributed to an increased level of $\mathrm{Ca}^{2+}$ in the haemolymph due to shell dissolution. This theory is also discussed by Beesley et al. (2008) to explain a significant decrease in health, as measured by the neutral red retention (NRR) assay, for $M$. edulis specimens incubated for 60 days at low $\mathrm{pH}$ levels ( -0.2 to $-0.7 \mathrm{pH}$ unit). The authors further validated the theory by suggesting that the observed $p \mathrm{CO}_{2}$ decrease (and $\mathrm{pH}$ increase) between the header tank (in which $\mathrm{CO}_{2}$ is added to fresh sea water) and the exposure tank (containing the organisms) at the lowest $\mathrm{pH}$ level, was due to the dissolution of mussel shells, although this hypothesis cannot be validated based on the presented data. Indeed, although it seems very likely that shell dissolution occurred at this $\mathrm{pH}$ level as sea water was undersaturated with respect to aragonite, it must be stressed that together with an increase in $\mathrm{pH}$ (and decrease in $p \mathrm{CO}_{2}$ ) between the header and exposure tanks, one should observe an increase 
in alkalinity and $\mathrm{TCO}_{2}$. This is obviously not the case as the authors reported similar alkalinity values and much lower $\mathrm{TCO}_{2}$ concentrations in the exposure tank as compared to the header tank, suggesting the predominance of another process in the $p \mathrm{CO}_{2}$ regulation (gas exchange and/ or photosynthesis). Nevertheless, whatever the reason, there is no doubt based on these results that even moderate decreases in $\mathrm{pH}$ have significant effects on shelled molluscs health and immune system. This has recently been confirmed by Matozzo et al. (2012) on two bivalve species: the Mediterranean mussel M. galloprovincialis and the clam Chamelea gallina.

Finally, differences in the accumulation of metals have also been documented in juveniles of the clam, Ruditapes philippinarum, where metal accumulation $(\mathrm{Zn}, \mathrm{Pb}, \mathrm{Cu}, \mathrm{Ni}$, $\mathrm{Cr}, \mathrm{Hg}$, As; but not $\mathrm{Cd}$ ) was found to increase upon exposure to elevated $p \mathrm{CO}_{2}$ for 28 days $(-1.0 \mathrm{pH}$ unit; Lopez et al. 2010). This highlights the potential ecotoxicological consequences that may be associated with ocean acidification stress in addition to the developmental and physiological effects that have been documented.

The results of the studies to date suggest that for a number of shelled mollusc species, ocean acidification will cause a rise in the cost of maintenance and a shift in energy budgets, unless acclimation across life-history stages or evolutionary adaptation occurs. The tissue and mechanisms responsible for such cost increments have not been identified; however, comparative findings in fish gills indicate that elevated costs of ion and acid-base regulation in gill tissue may be involved (Deigweiher et al. 2009). Future studies would benefit from assessment of the effects of ocean acidification on the entire energy budget of shelled molluscs to identify whether altered partitioning of the energy budget is occurring and which critical fitness-sustaining processes will be most vulnerable.

\section{Early-life-history stages}

It has been suggested that the early-life-history stages may be among the most vulnerable to increases in surface ocean $p \mathrm{CO}_{2}$ (Kurihara 2008). Negative effects on the early-lifehistory stages have the potential to create bottlenecks in shelled mollusc populations (Dupont et al. 2010) and shape the structure and function of these organisms and their ecosystems. As for adults and juveniles, early studies investigated the effects of low $\mathrm{pH}$ conditions on shelled mollusc gametes, embryos and larvae for other reasons than anthropogenic $\mathrm{CO}_{2}$-driven acidification (Calabrese and Davis 1966; Desrosiers et al. 1996; Wilson and Hyne 1997). Although these studies found negative impacts on organisms, they typically used mineral acids rather than $\mathrm{CO}_{2}$ to alter the carbonate chemistry of the experimental sea water. More recently, studies using the addition of $\mathrm{CO}_{2}$ to manipulate seawater carbonate chemistry have found adverse consequences for the early-life-history stages of shelled molluscs, at $\mathrm{pH}$ reductions much smaller than those used in the past (Tables 2, 3).

Fertilization is the first stage in the development of marine organisms, and for shelled molluscs, the reproductive strategy employed during fertilization differs across species. For the majority of bivalve species and some gastropods that are more primitive, fertilization occurs in the surrounding water; for example, eggs and sperm of bivalves are shed into the suprabranchial cavity where they are released into the water column with the exhalant current (Barnes 1974). Similarly in gastropods, eggs are swept out of the mantle cavity into the surrounding water either singly or as gelatinous masses (Barnes 1974). For these so-called "broadcast spawners", gametes may be directly affected by ocean acidification resulting in negative consequences for fertilization. In the other bivalve and gastropod species, fertilization of the egg occurs internally. The fertilized egg typically develops within the brooding female (bivalves) or in jelly masses, capsules or cases (gastropods) and is not released into the surrounding water column until a later-stage development, usually once the first veliger stage is reached (Barnes 1974). Species which employ internal fertilization may, therefore, be more robust than broadcast spawners to the effects of ocean acidification during fertilization.

Our knowledge of the impacts of ocean acidification on the fertilization on broadcast spawning shelled molluscs is based on a limited number of studies (9), covering only seven species (Table 2). $\mathrm{CO}_{2}$-induced hypercapnia is believed to have a narcotic effect on sperm, reducing its speed and motility, thereby reducing fertilization success (Havenhand et al. 2008; Byrne 2011; Reuter et al. 2011). However, in the water column sperm may overcome the effects of hypercapnia due to the respiratory dilution effects (increased oxygen tension) of sea water (see review from Byrne 2011). In the mussels Mytilus galloprovincialis and $M$. edulis and the abalone Haliotis coccoradiata, exposure to elevated $p \mathrm{CO}_{2}$ of $2,000 \mu \mathrm{atm}(-0.8 \mathrm{pH}$ unit), $1,400-1,500 \mu \mathrm{atm}(-0.5 \mathrm{pH}$ unit) and $800-1,700 \mu \mathrm{atm}$ ( -0.3 to $-0.6 \mathrm{pH}$ unit), respectively, caused no significant reduction in the percentage fertilization compared with the controls (Kurihara et al. 2008; Byrne et al. 2010; Bechmann et al. 2011). In the abalone Haliotis discus hannai (Kimura et al. 2011) and the clam Macoma balthica (Van Colen et al. 2012), there was no reduction in percentage fertilization at elevated $p \mathrm{CO}_{2}$ of $650-1,050 \mu \mathrm{atm}(-0.1$ to $-0.25 \mathrm{pH}$ unit) and $1,450 \mu \mathrm{atm}(-0.3 \mathrm{pH}$ unit), respectively, but there was a significant reduction in percentage fertilization at $p \mathrm{CO}_{2}$ above these levels $(-0.45$ to -0.55 pH unit H. discus hannai, Kimura et al. 2011; -0.6 pH unit M. balthica; Van Colen et al. 2012). Only in the oysters 
Table 2 Summary of the impacts of ocean acidification on the fertilization of shelled molluscs

\begin{tabular}{|c|c|c|c|c|c|c|c|c|c|c|c|c|}
\hline \multicolumn{3}{|l|}{ Fertilization } & \multicolumn{10}{|c|}{$\mathrm{pH}$ (unit decrease from ambient) } \\
\hline \multirow[t]{2}{*}{ Author/species } & \multicolumn{2}{|l|}{ Process-impact } & \multicolumn{4}{|c|}{ Projected 2100} & \multicolumn{6}{|c|}{ Projected 2300} \\
\hline & & & -0.1 & -0.2 & -0.3 & -0.4 & -0.5 & -0.6 & -0.7 & -0.8 & -0.9 & -1.0 \\
\hline \multicolumn{13}{|l|}{ Bivalves } \\
\hline \multicolumn{13}{|l|}{ Bechmann et al. (2011) } \\
\hline Mytilus edulis (mussel) & Fertilization & $=$ & & & & & $\bigcirc$ & & & & & \\
\hline \multicolumn{13}{|l|}{ Havenhand and Schlegel (2009) } \\
\hline \multirow[t]{3}{*}{ Crassostrea gigas (oyster) } & Sperm swimming speed & $=$ & & & $\bigcirc$ & & & & & & & \\
\hline & Sperm motility & $=$ & & & O & & & & & & & \\
\hline & Fertilization & $=$ & & & $\bigcirc$ & & & & & & & \\
\hline \multicolumn{13}{|l|}{ Kurihara et al. (2007) } \\
\hline Crassostrea gigas (oyster) & Fertilization & $=$ & & & & & & & & $\bigcirc$ & & \\
\hline \multicolumn{13}{|l|}{ Kurihara et al. (2008) } \\
\hline Mytilus galloprovincialis (mussel) & Fertilization & $=$ & & & & & & & & $\bigcirc$ & & \\
\hline \multicolumn{13}{|l|}{ Parker et al. (2009; 2010) } \\
\hline Crassostrea gigas (oyster) & Fertilization & $\downarrow$ & & ○ & ○ & - & & & & & & \\
\hline Saccostrea glomerata (oyster) & Fertilization & $\downarrow$ & & ○ & ○ & - & & & & & & \\
\hline \multicolumn{13}{|l|}{ Van Colen et al. (2012) } \\
\hline Macoma balthica (clam) & Fertilization & $\downarrow$ & & & $\bigcirc$ & & & ○ & & & & \\
\hline \multicolumn{13}{|l|}{ Gastropods } \\
\hline \multicolumn{13}{|l|}{ Byrne et al. (2010) } \\
\hline Haliotis coccoradiata (abalone) & Fertilization & $=$ & & & $\bigcirc$ & & & $\bigcirc$ & & & & \\
\hline \multicolumn{13}{|l|}{ Kimura et al. (2011) } \\
\hline \multirow[t]{2}{*}{ Haliotis discus hannai (abalone) } & Fertilization & $=$ & O & $\bigcirc$ & ○ & & & & & & & \\
\hline & Fertilization & $\downarrow$ & & & b & - & - & & & & & \\
\hline
\end{tabular}

In bold, studies considering more than one stressor (e.g. temperature, salinity, food availability, etc.). Open and full circles refer to not significant and significant effects, respectively

Saccostrea glomerata and Crassostrea gigas, exposure to moderately elevated $p \mathrm{CO}_{2}$ levels (600-1,000 $\mu$ atm) caused a significant reduction in percentage fertilization (Parker et al. 2009, 2010). Despite the oysters occupying similar habitats, the extent of this reduction in percentage fertilization differed between the two species, being much greater for $S$. glomerata than $C$. gigas. When elevated $\mathrm{CO}_{2}$ was combined with suboptimal temperature $\left(18^{\circ} \mathrm{C}\right.$ for $S$. glomerata; $30{ }^{\circ} \mathrm{C}$ for $C$. gigas), the number of fertilized eggs was reduced by up to 51 and $26 \%$ for S. glomerata and $C$. gigas, respectively, at elevated $p \mathrm{CO}_{2}(1,000 \mu \mathrm{atm})$ compared with the controls $\left(375 \mu \mathrm{atm} ; 26{ }^{\circ} \mathrm{C}\right.$; Parker et al. 2010).

Finally, even identical species have shown differing responses of fertilization to ocean acidification. For example, gametes of the Pacific oyster, C. gigas, from populations in Japan (Kurihara et al. 2007) and Sweden (Havenhand and Schlegel 2009) experienced no reduction in percentage fertilization, sperm swimming speed and motility (sperm tested only in the Swedish population) when reared at elevated $p \mathrm{CO}_{2}$ of $1,000-2,300 \mu \mathrm{atm}(-0.3$ to $-0.8 \mathrm{pH}$ unit). In a study performed on an Australian population of $C$. gigas, however, there was a significant reduction in percentage fertilization at elevated $\mathrm{CO}_{2}(-0.2$, -0.3 and $-0.4 \mathrm{pH}$ unit) compared with control conditions (Parker et al. 2010). It was first thought that these differences were the result of variations in experimental design; however, a repeat of the experiment using the same design revealed similar results (Parker et al., unpublished data). This suggests that intraspecific variation may exist between populations due to both environmental and genetic differences that may lead to within-species differences in fertilization response to ocean acidification stress.

The conflicting results of these studies (see Fig. 5) highlight the complex nature of measuring fertilization responses in shelled molluscs during exposure to elevated $p \mathrm{CO}_{2}$. In some shelled mollusc species, there is no effect of ocean acidification on fertilization, in some fertilization was significantly reduced, while in others the effects of ocean acidification on fertilization differ even between members of the same species. In order to make more realistic projections of the effects of ocean acidification on this pivotal stage in the life cycle of shelled molluscs, it may be necessary to adopt standardized experimental 


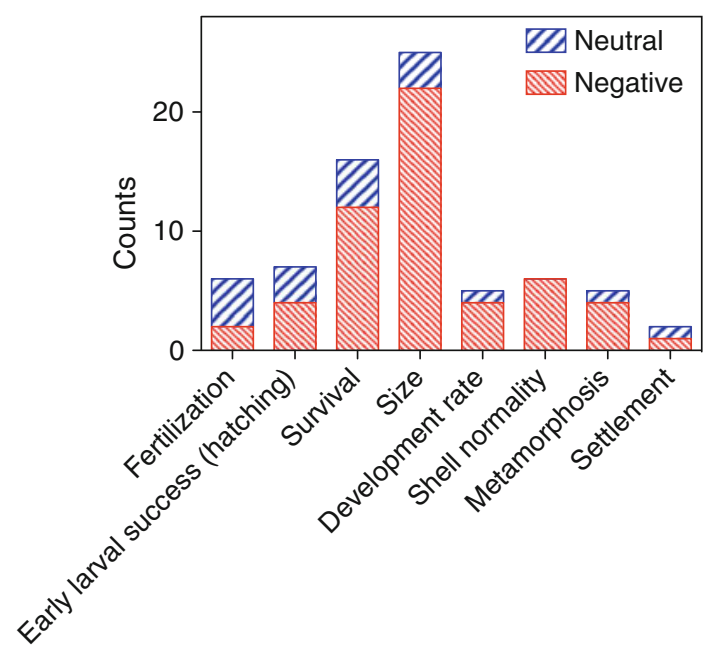

Fig. 5 Summary of the impacts of ocean acidification on the fertilization and the larval development of shelled molluscs for studies considering a $\mathrm{pH}$ decrease lower than 0.4 unit

protocols. This will remove differences in species responses that are known to occur due to differences in experimental design. Reuter et al. (2011), for example, found that as $p \mathrm{CO}_{2}$ increases so too does the sperm concentration required for optimal percentage fertilization. Negative effects of ocean acidification on fertilization may, therefore, not be observed if the sperm-egg ratio is too high. Sperm quality and egg-sperm compatibility may also influence percentage fertilization (Boudry et al. 2002; Byrne 2011) as well as the method used to obtain gametes, the use of polyandry versus single crosses, the time allowed for fertilization to take place (minutes vs. hours), whether excess sperm are rinsed from the eggs and the characteristic used to score fertilization (fertilization envelope vs. cleavage plane, Byrne 2011; Wicks and Roberts 2012).

While the effects of ocean acidification on fertilization have been somewhat conflicting, the embryonic and larval development of marine shelled molluscs has been found to be particularly vulnerable to increased $p \mathrm{CO}_{2}$ (Table 3; Fig. 5), even in species that are resilient during fertilization. When embryos of the Pacific oyster, C. gigas, were reared at elevated $p \mathrm{CO}_{2}$ of $2,300 \mu \mathrm{atm}(-0.8 \mathrm{pH}$ unit) for $48 \mathrm{~h}$, there was no significant difference in the percentage of normal development relative to the controls until the trochophore stage (Kurihara et al. 2007) and the onset of shell mineralization (Waller 1981; Hayakaze and Tanabe 1999; Kurihara et al. 2007). At the completion of the experiment, the embryos of $C$. gigas were found to have reduced rates of development, calcification and growth and increased rates of abnormal development, with only $5 \%$ of the $\mathrm{CO}_{2}$-stressed embryos developing normally to D-stage larvae compared with $68 \%$ in the controls (Kurihara et al. 2007). Similar results were found by Parker et al. (2009, 2010) on the Pacific oyster C. gigas and the Sydney rock oyster $S$. glomerata. In a series of acute exposure experiments (2-4 days), they reared embryos, larvae and newly metamorphosed spat at one ambient (380 $\mu \mathrm{atm})$ and three elevated concentrations of $p \mathrm{CO}_{2}(600,750$ and $1,000 \mu \mathrm{atm}$; -0.2 to $-0.4 \mathrm{pH}$ unit) and found that the number of larvae that developed and the size of larvae decreased linearly with increasing $p \mathrm{CO}_{2}$. In addition, there was an increase in abnormal development of larvae with increasing $p \mathrm{CO}_{2}$. These deleterious effects were greater in the presence of suboptimal temperature (temperature that deviated from $\left.26{ }^{\circ} \mathrm{C}\right)$. Similar decreases in larval size and increases in abnormal development were reported for $S$. glomerata in a study by Watson et al. (2009) and Parker et al. (2012). Further, for the oyster, C. virginica, survival, size and metamorphosis were reduced and development time was increased during a 20 days exposure to elevated $p \mathrm{CO}_{2}$ $(-0.5 \mathrm{pH}$ unit for survival, $-0.2 \mathrm{pH}$ unit for size and development time; Talmage and Gobler 2010; Talmage and Gobler 2012). Not all oyster species, however, respond similarly to elevated $\mathrm{CO}_{2}$. In fact, even closely related species from identical geographic locations have had different responses. Miller et al. (2009), for example, measured the effects of estuarine acidification on two oyster species found in Chesapeake Bay ( $C$. virginica and C. ariakensis). Larvae of these two species were grown under four $p \mathrm{CO}_{2}$ regimes $(280,380,560$ and $800 \mu \mathrm{atm}$; +0.1 , control, -0.15 and $-0.3 \mathrm{pH}$ unit). While shell area and $\mathrm{CaCO}_{3}$ content of $C$. virginica larvae were significantly lower at the highest $p \mathrm{CO}_{2}$ level compared with both control and moderately high $p \mathrm{CO}_{2}$ conditions, $C$. ariakensis showed no change to either growth or calcification among the different $p \mathrm{CO}_{2}$ levels. There was also no effect of elevated $\mathrm{CO}_{2}$ ( -0.2 to $-0.7 \mathrm{pH}$ unit) on the Portuguese oyster C. angulata (Thiyagarajan and Ko 2012). Larvae of $C$. angulata showed no significant reduction in size after 5 days of exposure to elevated $\mathrm{CO}_{2}(-0.2,-0.5,-0.7 \mathrm{pH}$ unit) when salinity was optimal (34), but a significant reduction in size at the lowest $\mathrm{pH}$ level when salinity was reduced (27). Many shelled mollusc species occupy habitats characterized by substantial fluctuations in salinity, yet Thiyagarajan and Ko (2012) is the only study to date that has assessed the synergistic impacts of elevated $\mathrm{CO}_{2}$ and fluctuating salinity on the early-life-history stage of a shelled mollusc.

In embryos of the mussel, $M$. galloprovincialis, there was no effect of exposure to elevated $p \mathrm{CO}_{2}$ of 2,000 $\mu \mathrm{atm}$ $(-0.8 \mathrm{pH}$ unit) until the late trochophore stage (Kurihara et al. 2008). Following this time, the mussels developed shell abnormalities including protrusions of the mantle and convex hinge, reductions in both shell height and length as well as an increase in development time. Similar results were found in the mussels M. edulis (Gazeau et al. 2010) and M. trossulus (Sunday et al. 2011), where larvae 
Table 3 Summary of the impacts of ocean acidification on the embryonic and larval development of shelled molluscs

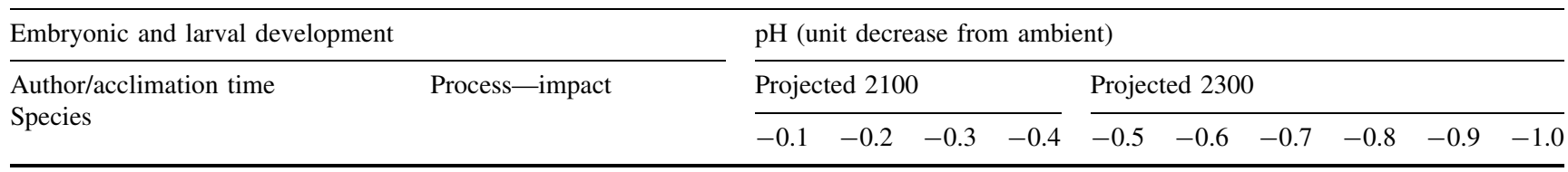

Bivalves

Bechmann et al. (2011; 60 days)

Mytilus edulis (mussel)

Dineshram et al. (2012; 6 d)

Crassostrea gigas (oyster)

Gaylord et al. (2011; 8 days)

Mytilus californianus (mussel)

Gazeau et al. (2010; 16 days)

Mytilus edulis (mussel)

Gazeau et al. (2011; 3 days)

Crassostrea gigas (oyster)

Kurihara et al. (2007; 2 days)

Crassostrea gigas (oyster)

Kurihara et al. (2008; 6 days)

Mytilus galloprovincialis (mussel)

Miller et al. (2009; 32 days)

Crassostrea virginica (oyster)

Crassostrea ariakensis (oyster)

Parker et al. (2009, 2010; 2 days)

Saccostrea glomerata (oyster)

Crassostrea gigas (oyster)

Parker et al. (2012; 19 days)

Saccostrea glomerata (oyster)
Development speed =

Shell normality

Feeding rate

Size

Protein expression

Shell area

Shell strength

Shell thickness

Tissue mass

Survival

Hatching

Size

Hatching

Size

Calcium incorporation

$=$

Development speed

Survival

Shell normality

Size

Development speed Shell normality

Size

Shell area $\downarrow \downarrow$

Shell $\mathrm{CaCO}_{3}$ content $\downarrow$

Shell area $\quad=0$

Shell $\mathrm{CaCO}_{3}$ content $=0$

Development (\%)

Shell normality

Size

Development (\%)

Shell normality

Size

Survival

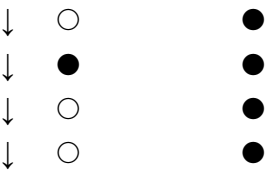

$\begin{array}{ll}= & 0 \\ \downarrow & 0 \\ \downarrow & 0\end{array}$

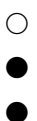


Table 3 continued

\begin{tabular}{|c|c|c|c|c|c|c|c|c|c|c|c|c|}
\hline \multicolumn{3}{|l|}{ Embryonic and larval development } & \multicolumn{10}{|c|}{$\mathrm{pH}$ (unit decrease from ambient) } \\
\hline \multirow{4}{*}{$\begin{array}{l}\text { Author/acclimation time } \\
\text { Species }\end{array}$} & \multirow{2}{*}{\multicolumn{2}{|c|}{ Process_impact }} & \multicolumn{4}{|c|}{ Projected 2100} & \multicolumn{6}{|c|}{ Projected 2300} \\
\hline & & & -0.1 & -0.2 & -0.3 & -0.4 & -0.5 & -0.6 & -0.7 & -0.8 & -0.9 & -1.0 \\
\hline & Development $(\%)$ & $\downarrow$ & & & - & & & & & & & \\
\hline & Size & $\downarrow$ & & & • & & & & & & & \\
\hline \multicolumn{13}{|l|}{ Sunday et al. (2011; 3 days) } \\
\hline Mytilus trossolus (mussel) & Shell length & $\downarrow$ & & & $\bullet$ & & & & & & & \\
\hline \multicolumn{13}{|l|}{ Talmage and Gobler (2009; 20 days) } \\
\hline \multirow[t]{3}{*}{ Crassostrea virginica (oyster) } & Survival & $\downarrow$ & & O & & & $\bullet$ & & & & & \\
\hline & Development speed & $\downarrow$ & & 0 & & & ○ & & & & & \\
\hline & Size & $\downarrow$ & & • & & & ○ & & & & & \\
\hline \multirow[t]{3}{*}{ Mercenaria mercenaria (clam) } & Survival & $\downarrow$ & & ○ & & & - & & & & & \\
\hline & Development speed & $\downarrow$ & & ○ & & & 0 & & & & & \\
\hline & Size & $\downarrow$ & & - & & & - & & & & & \\
\hline \multirow[t]{3}{*}{ Argopecten irradians (scallop) } & Survival & $\downarrow$ & & $\bullet$ & & & $\bullet$ & & & & & \\
\hline & Development speed & $\downarrow$ & & $\bullet$ & & & $\bullet$ & & & & & \\
\hline & Size & $\downarrow$ & & ○ & & & ○ & & & & & \\
\hline \multicolumn{13}{|l|}{ Talmage and Gobler (2010; 36 days) } \\
\hline \multirow[t]{4}{*}{ Mercenaria mercenaria (clam) } & Survival & $\downarrow$ & & $\bullet$ & & & $\bullet$ & & & & & \\
\hline & Shell thickness & $\downarrow$ & & - & & & - & & & & & \\
\hline & Shell diameter & $\downarrow$ & & $\bullet$ & & & $\bullet$ & & & & & \\
\hline & Lipid index & $\downarrow$ & & $\bullet$ & & & $\bullet$ & & & & & \\
\hline \multirow[t]{4}{*}{ Argopecten irradians (scallop) } & Survival & $\downarrow$ & & $\bullet$ & & & $\bullet$ & & & & & \\
\hline & Shell thickness & $\downarrow$ & & $\bullet$ & & & $\bullet$ & & & & & \\
\hline & Shell diameter & $\downarrow$ & & $\bullet$ & & & $\bullet$ & & & & & \\
\hline & Lipid index & $\downarrow$ & & $\bullet$ & & & $\bullet$ & & & & & \\
\hline \multicolumn{13}{|c|}{ Talmage and Gobler $(2011 ; \mathbf{2 0}$ days $)$} \\
\hline \multirow[t]{4}{*}{ Mercenaria mercenaria (clam) } & Metamorphosis & $\downarrow$ & & & $\bullet$ & & & & & & & \\
\hline & Survival & $\downarrow$ & & & 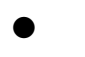 & & & & & & & \\
\hline & Shell diameter & $\downarrow$ & & & ○ & & & & & & & \\
\hline & Lipid index & $\downarrow$ & & & $\bullet$ & & & & & & & \\
\hline \multirow[t]{4}{*}{ Argopecten irradians (scallop) } & Metamorphosis & $\downarrow$ & & & $\bullet$ & & & & & & & \\
\hline & Survival & $\downarrow$ & & & $\bullet$ & & & & & & & \\
\hline & Shell diameter & $\downarrow$ & & & $\bullet$ & & & & & & & \\
\hline & Lipid index & $\downarrow$ & & & $\bullet$ & & & & & & & \\
\hline \multicolumn{13}{|c|}{ Talmage and Gobler (2012; 20 days) } \\
\hline \multirow[t]{4}{*}{ Crassostrea virginica (oyster) } & Metamorphosis & $\downarrow$ & & $\bullet$ & & & & & & & & \\
\hline & Survival & $\downarrow$ & & $\bullet$ & & & & & & & & \\
\hline & Shell diameter & $\downarrow$ & & $\bullet$ & & & & & & & & \\
\hline & Lipid index & $\downarrow$ & & - & & & & & & & & \\
\hline \multirow[t]{4}{*}{ Argopecten irradians (scallop) } & Metamorphosis & $\downarrow$ & ○ & & $\bullet$ & & & & & & & \\
\hline & Survival & $\downarrow$ & - & & $\bullet$ & & & & & & & \\
\hline & Shell diameter & $\downarrow$ & $\bullet$ & & ○ & & & & & & & \\
\hline & Lipid index & $\downarrow$ & • & & $\bullet$ & & & & & & & \\
\hline Thiyagarajan and Ko (2012; 5 d & & & & & & & & & & & & \\
\hline Crassostrea angulata (oyster) & Shell growth & $\downarrow$ & & $\bigcirc$ & & & ○ & & ○ & & & \\
\hline
\end{tabular}


Table 3 continued

\begin{tabular}{|c|c|c|c|c|c|c|c|c|c|c|c|c|c|}
\hline \multicolumn{3}{|l|}{ Embryonic and larval development } & \multicolumn{11}{|c|}{$\mathrm{pH}$ (unit decrease from ambient) } \\
\hline \multirow{2}{*}{$\begin{array}{l}\text { Author/acclimation time } \\
\text { Species }\end{array}$} & \multirow[t]{2}{*}{ Process-impact } & & \multicolumn{5}{|c|}{ Projected 2100} & \multicolumn{6}{|c|}{ Projected 2300} \\
\hline & & & -0.1 & -0 & & -0.3 & -0.4 & -0.5 & -0.6 & -0.7 & -0.8 & -0.9 & -1.0 \\
\hline \multirow[t]{4}{*}{ Crassostrea gigas (oyster) } & Survival (day 1) & $=$ & & $\bigcirc$ & & $\bigcirc$ & & & & & & & \\
\hline & Hatching (day 1) & $=$ & & $\bigcirc$ & & $\bigcirc$ & & & & & & & \\
\hline & Shell growth (day 1) & $\uparrow$ & & $\bigcirc$ & & $\bullet$ & & & & & & & \\
\hline & Shell growth (day 3) & $\downarrow$ & & $\bigcirc$ & & - & & & & & & & \\
\hline \multicolumn{14}{|l|}{ Van Colen et al. (2012; 19 days) } \\
\hline \multirow[t]{5}{*}{ Macoma balthica (clam) } & Hatching & $\downarrow$ & & & & - & & & - & & & & \\
\hline & Shell size & $\downarrow$ & & & & - & & & - & & & & \\
\hline & Mortality & $\downarrow$ & & & & $\bigcirc$ & & & - & & & & \\
\hline & Growth & $\downarrow$ & & & & - & & & - & & & & \\
\hline & Metamorphosis & $=$ & & & & $\bigcirc$ & & & $\bigcirc$ & & & & \\
\hline \multicolumn{14}{|l|}{ Watson et al. (2009; 8 days) } \\
\hline \multirow[t]{3}{*}{ Saccostrea glomerata (oyster) } & Shell normality & $\downarrow$ & & & & ○ & & - & & & & & \\
\hline & Survival & $\downarrow$ & & & & ○ & & - & & & & & \\
\hline & Size & $\downarrow$ & & & & ○ & & - & & & & & \\
\hline \multicolumn{14}{|l|}{ Gastropods } \\
\hline \multicolumn{14}{|l|}{ Byrne et al. (2011; 5 days) } \\
\hline Haliotis coccoradiata (abalone) & Calcified larvae & $\downarrow$ & & & & & ○ & & - & & & & \\
\hline \multicolumn{14}{|l|}{ Crim et al. (2011; 8 days) } \\
\hline \multirow[t]{3}{*}{ Haliotis kamtschatkana (abalone) } & Survival & $\downarrow$ & & ○ & & & & ○ & & & & & \\
\hline & Shell length & $\downarrow$ & & $\bullet$ & & & & & & & & & \\
\hline & Shell normality & $\downarrow$ & & ○ & & & & ○ & & & & & \\
\hline \multicolumn{14}{|l|}{ Ellis et al. (2009; 21 days) } \\
\hline \multirow[t]{5}{*}{ Littorina obtusata (snail) } & Development speed & $\downarrow$ & & & & & & ○ & & & & & \\
\hline & Viability & $\downarrow$ & & & & & & $\bullet$ & & & & & \\
\hline & Heart rate & $\downarrow$ & & & & & & ○ & & & & & \\
\hline & Behaviour & $\downarrow$ & & & & & & $\bullet$ & & & & & \\
\hline & Shell morphology & $\downarrow$ & & & & & & $\bullet$ & & & & & \\
\hline \multicolumn{14}{|l|}{ Kimura et al. (2011; 15 h) } \\
\hline \multirow[t]{6}{*}{ Haliotis discus hannai (abalone) } & Hatching rate & $\uparrow$ & $\bullet$ & $\bullet$ & ○ & & & & & & & & \\
\hline & Hatching rate & $\downarrow$ & & & $\bigcirc$ & & ○ & $\bullet$ & & & & & \\
\hline & Survival & $=$ & $\bigcirc$ & $\bigcirc$ & $\bigcirc$ & & & & & & & & \\
\hline & Survival & $=$ & & & $\bigcirc$ & & $\bigcirc$ & $\bigcirc$ & & & & & \\
\hline & Shell normality & $=$ & $\bigcirc$ & $\bigcirc$ & $\bigcirc$ & & & & & & & & \\
\hline & Shell normality & $\downarrow$ & & & ○ & & $\bullet$ & ○ & & & & & \\
\hline \multicolumn{14}{|l|}{ Zippay and Hofmann (2010; 6 days) } \\
\hline \multirow[t]{2}{*}{ Haliotis rufescens (abalone) } & Thermal tolerance & $\downarrow$ & $\bullet$ & $\bullet$ & & & & & & & & & \\
\hline & ap24 expression & $=$ & $\bigcirc$ & $\bigcirc$ & & & & & & & & & \\
\hline
\end{tabular}

In bold, studies considering more than one stressor (e.g. temperature, salinity, food availability, etc.). Open and full circles refer to not significant and significant effects, respectively

exhibited a reduction in size and shell thickness (for M. edulis only) when reared in $\mathrm{CO}_{2}$-acidified sea water $(-0.3 \mathrm{pH}$ unit) compared with the controls. In addition, for M. edilus, when sea water was further acidified $(-0.5 \mathrm{pH}$ unit), there was a $24 \%$ reduction in hatching rates (Gazeau et al. 2010). In the mussel M. californianus, a critical community member on rocky shores throughout the northeastern Pacific, Gaylord et al. (2011) showed that elevated $p \mathrm{CO}_{2}$ levels $(-0.1,-0.3 \mathrm{pH}$ unit) markedly degraded the mechanical integrity of larval shells. Larvae grown at the highest $p \mathrm{CO}_{2}$ treatment $(-0.3 \mathrm{pH}$ unit) precipitated thinner and smaller shells and exhibited lower tissue mass than 
individuals grown in the control or at the intermediate $p \mathrm{CO}_{2}$ level. Shells were weaker at the low $\mathrm{pH}$ levels than the ones precipitated under control conditions. Despite the overwhelmingly negative effects of ocean acidification on mussel embryos and larvae that have been documented to date, even identical species can differ in their responses. In a recent study by Bechmann et al. (2011), exposure of larvae of $M$. edulis to elevated $p \mathrm{CO}_{2}$, a species previously found to be vulnerable to ocean acidification stress (Gazeau et al. 2010), had no effect on the development time, abnormality, feeding rate or settlement of larvae reared for $48 \mathrm{~h}$ following a $\mathrm{pH}$ decrease of $-0.5 \mathrm{pH}$ unit. There was, however, an effect of reduced $\mathrm{pH}$ on larval size. After 2 months of exposure to elevated $p \mathrm{CO}_{2}$, larvae were $28 \%$ smaller in the elevated $p \mathrm{CO}_{2}$ treatment when compared to the controls.

In the clam Macoma balthica, exposure to elevated $\mathrm{CO}_{2}$ $(-0.3$ and $-0.6 \mathrm{pH}$ unit) caused a significant reduction in hatching success, larval size and survival $(-0.6 \mathrm{pH}$ unit only) but had no effect on metamorphosis (Van Colen et al. 2012). Reductions in larval size were also documented for the clam Mercenaria mercenaria and the scallop Argopecten irradians in response to elevated $p \mathrm{CO}_{2}(-0.2$ to $-0.24 \mathrm{pH}$ unit; Talmage and Gobler 2009, 2010, 2011, 2012). Shell thickness, shell diameter, development rate (for M. mercenaria only), survival, lipid index and metamorphosis (for A. irradians but not M. mercenaria) were reduced in both species at elevated compared with ambient $p \mathrm{CO}_{2}$. The authors of these experiments suggested that the level of ocean acidification that has occurred since the industrial revolution has already had measurable effects on the larvae of M. mercenaria and A. irradians. When reared at a preindustrial $p \mathrm{CO}_{2}$ level, larvae of these species displayed thicker, more robust shells than larvae that were reared at the present-day $p \mathrm{CO}_{2}$ level (Talmage and Gobler 2010). However, these larvae may now be pre-adapted to present-day conditions and still show a putative beneficial effect (thicker shells) of pre-industrial $\mathrm{CO}_{2}$ levels. Given this, it is possible but not yet clear whether declines in shelled mollusc populations that have been reported over recent decades are in part related to ocean acidification.

In the gastropods studied to date, there was an increase in development time and reduced viability in encapsulated embryos of the intertidal snail, Littorina obtusata, following exposure to elevated $p \mathrm{CO}_{2}$ of 1,100 $\mu \mathrm{atm}$ (Ellis et al. 2009). In addition, hatchlings had altered morphology and behaviour and lower heart rates, compared with control snails. Decreased hatching rates and increased shell abnormalities (but similar survival) have also been found for the abalone Haliotis discus hannai following a $\mathrm{pH}$ decrease of -0.45 to -0.55 with no significant effects at higher pH levels (Kimura et al. 2011). Byrne et al. (2011) studied the synergistic effects of ocean acidification and warming on the abalone Haliotis coccoradiata $(-0.4$ and $-0.6 \mathrm{pH}$ unit; +2 and $+4{ }^{\circ} \mathrm{C}$ ). They found that the percentage of calcified larvae was significantly lower in the low $\mathrm{pH}$ and in the high temperature treatments compared with controls. Furthermore, no significant interaction between factors was observed, with a consistent pattern across temperature at each $\mathrm{pH}$. In the abalone Haliotis rufescens, a $-0.2 \mathrm{pH}$ unit reduction led to a decrease in the thermal tolerance of some larval stages (Zippay and Hofmann 2010). Finally, in the northern abalone Haliotis kamtschatkana, exposure to elevated $\mathrm{CO}_{2}$ for 8 days caused a significant reduction in survival and size and increase in shell abnormalities, but had no effect on settlement (Crim et al. 2011).

In a large number of studies that have assessed the impacts of ocean acidification on shelled mollusc larvae, fertilization has been done under ambient conditions following which fertilized embryos were transferred into the elevated $p \mathrm{CO}_{2}$ conditions. This methodology ignores positive or negative carryover effects which may be passed from one developmental stage to the next. For example, in the oyster $S$. glomerata exposure of larvae to elevated $\mathrm{CO}_{2}$ $\left(-0.4 \mathrm{pH}\right.$ unit) and temperature $\left(+4{ }^{\circ} \mathrm{C}\right)$ for $24 \mathrm{~h}$ following fertilization in ambient conditions caused a $65 \%$ reduction in development success. Exposure of $S$. glomerata larvae to elevated $\mathrm{CO}_{2}\left(-0.4 \mathrm{pH}\right.$ unit) and temperature $\left(+4{ }^{\circ} \mathrm{C}\right)$ for $24 \mathrm{~h}$ following fertilization at elevated $\mathrm{CO}_{2}$, however, caused $100 \%$ mortality of larvae (Parker et al. 2009, 2010). In the same species, exposure of adult $S$. glomerata to elevated $\mathrm{CO}_{2}$ during reproductive condition led to positive carryover effects in the larvae (Parker et al. 2012). Larvae from parents exposed to elevated $\mathrm{CO}_{2}$ were larger in size and developed faster, but had similar survival when exposed to the same level of elevated $\mathrm{CO}_{2}$ compared with larvae from parents that were exposed to ambient $\mathrm{CO}_{2}$. Both of these studies highlight the importance of assessing carryover when determining species responses to ocean acidification.

A common impact of ocean acidification on the early developmental stages of most shelled mollusc species studied is a reduction in the rate of larval development and a reduction in larval size (Table 3). At present, however, the underlying mechanisms associated with the responses of shelled mollusc embryos and larvae to ocean acidification are poorly understood. It has been suggested that like juveniles and adults, one of the major physiological processes affected by elevated $\mathrm{CO}_{2}$ in embryos and larvae is calcification. As such, calcifying developmental stages may be more vulnerable than earlier, non-calcifying stages to ocean acidification. Indeed, studies on the oyster C. gigas (Kurihara et al. 2007) and the mussel M. galloprovincialis (Kurihara et al. 2008) showed that the onset of negative effects of elevated $p \mathrm{CO}_{2}$ coincided with the 
beginning of shell formation (during the trochophore stage), with no noticeable effects compared with the controls prior to this time.

In addition to calcification, it has also been suggested that ocean acidification may impact on the feeding efficiency of shelled mollusc larvae. As a result, the impacts of ocean acidification may be expected to be greater for feeding compared with non-feeding developmental stages. In a study by Timmins-Schiffman et al. (2012; this issue), there was no effect of elevated $\mathrm{CO}_{2}$ on the survival and size of larvae of the oyster C. gigas after 1 day of exposure, when exogenous feeding had not begun. After 3 days of exposure and the onset of exogenous feeding, however, both survival and size of the larvae were significantly reduced. Only one study to date has directly measured the impact of ocean acidification on feeding rate in shelled mollusc larvae. Bechmann et al. (2011) found that there was no effect of elevated $\mathrm{CO}_{2}(-0.5 \mathrm{pH}$ unit) on the feeding rate of larvae of the mussel M. edulis. In a study by Talmage and Gobler (2012), however, a compromise in the hinge structure of larvae of the clam $M$. mercenaria and scallop A. irradians following exposure to elevated $p \mathrm{CO}_{2}$ was suggested to decrease the ability of the larvae to obtain food, as evidenced by the significant reduction in lipid index following exposure in the elevated $p \mathrm{CO}_{2}$ treatment. Only 2 studies have considered the gene and protein expression pattern of shelled mollusc larvae during exposure to elevated $p \mathrm{CO}_{2}$ (Zippay and Hofmann 2010; Dineshram et al. 2012). A recent study by Dineshram et al. (2012) found that exposure of larvae of the oyster $C$. angulata to elevated $p \mathrm{CO}_{2}(-0.5 \mathrm{pH}$ unit) for 4 days following fertilization caused either a downregulation or loss of 71 proteins. The authors suggested a widespread depression of metabolic gene expression during ocean acidification stress. In contrast, Zippay and Hofmann (2010) found no effect of elevated $p \mathrm{CO}_{2}$ on the gene expression of two genes central to shell formation in larvae of the red abalone Haliotis rufescens. However, genes involved in metabolism were not measured.

Finally, Gazeau et al. (2011) assessed the impact of several carbonate-system perturbations on the growth of Pacific oyster (C. gigas) larvae during the first 3 days of development. The objective was to allow the discrimination between the physiological effects of $\mathrm{pH}$ decrease, via a disruption of intercellular transport mechanisms and the effects of the aragonite saturation state, on the larval development of this species. Sea water with five different chemistries was obtained by separately manipulating $\mathrm{pH}$, total alkalinity and aragonite saturation state (calcium addition). Results showed that the developmental success and growth rates of this species were not directly affected by changes in $\mathrm{pH}(-0.3$ to $-0.6 \mathrm{pH}$ unit) or aragonite saturation state, but were highly correlated with the availability of carbonate ions. In contrast to previous studies, both developmental success and growth rates were not significantly altered as long as carbonate ion concentrations were above aragonite saturation levels, but they strongly decreased below saturation levels. This result highlights the importance of measuring the $\mathrm{CaCO}_{3}$ saturation levels in ocean acidification experiments and suggests that $\mathrm{CaCO}_{3}$ saturation levels, rather than $\mathrm{pH}$ or $\mathrm{CO}_{2}$, may be the key determinant of negative effects on marine shelled molluscs.

Overall, the embryos and larvae of shelled molluscs are highly vulnerable to ocean acidification stress, with far more negative effects than on juveniles and/or adults (see Fig. 5). The $\mathrm{CaCO}_{3}$ polymorphs deposited during embryonic and larval development (mostly ACC and aragonite) are expected to be more soluble (Brečević and Nielsen 1989) in an acidifying ocean than the $\mathrm{CaCO}_{3}$ that is deposited following settlement and metamorphosis. Shell size, thickness and normality, rate of development and survival of embryos and larvae are all negatively affected by elevated $\mathrm{CO}_{2}$. Effects on metamorphosis and settlement have been less studied with results to date revealing both neutral (Bechmann et al. 2011; Crim et al. 2011) and negative (Cigliano et al. 2010; Talmage and Gobler 2012) effects of elevated $\mathrm{CO}_{2}$ on these critical stages. There is a limited understanding of the underlying mechanisms associated with the responses of the early-life-history stages of shelled molluscs to ocean acidification. There are both species-specific and within-species responses which exist for embryos and larvae during exposure to elevated $\mathrm{CO}_{2}$, and these responses require further investigation before they can be completely understood. To help discern current trends in the literature and identify which shelled molluscs species will be most vulnerable in a high- $\mathrm{CO}_{2}$ world, future experiments should directly consider the environment which a species is collected from, the $\mathrm{CaCO}_{3}$ saturation state of experimental sea water, the characteristics of the developmental stage (feeding vs. non-feeding, shell vs. no shell), and whether embryos and larvae are exposed for one or multiple development stages of their early development.

\section{Pteropods}

In contrast to many other molluscs, pteropods are holoplanktonic: their entire life cycle is planktonic. They are widely distributed and are a key food source for predators such as zooplankton, fishes and birds (Lalli and Gilmer 1989). Since they are particularly abundant in high-latitude regions and have external aragonitic shells, they are among the calcifiers most vulnerable to the effects of seawater corrosive for $\mathrm{CaCO}_{3}$ (Steinacher et al. 2009). For this reason, most of studies of the effects of ocean acidification on pteropods have 
been performed on high-latitude speciacross temperature at each pH. In the abalonees (Orr et al. 2005; Comeau et al. 2009, 2010b; Lischka et al. 2011; Lischka and Riebesell 2012; Manno et al. 2012; Seibel et al. 2012; Table 4) and over relatively short-time scales as these organisms remain very difficult to cultivate (Comeau et al. 2010b).

Similar to studies on benthic shelled molluscs, the precipitation and dissolution of shells are the processes that have been investigated the most (see Fig. 6). Signs of shell dissolution were first reported in live Clio pyramidata from the Subarctic Pacific after a 48-h exposure to corrosive conditions (Orr et al. 2005). Investigations of shell degradation as a function of $\mathrm{pH}$ followed for juveniles of the Arctic pteropod Limacina helicina (Lischka et al. 2011; Comeau et al. 2012), adults of the Antartic species Limacina helicina and Clio pyramidata (Bednaršek et al. 2012a), and adults of the subpolar pteropod Limacina retroversa (Lischka et al. 2011; Manno et al. 2012). These studies reported an increase in shell degradation as a function of decreasing $\mathrm{pH}$. Temperature does not seem to play an important role in shell degradation (Lischka et al. 2011), whereas a decrease in salinity appeared to enhance the effect of low pH (Manno et al. 2012).

Calcification has been measured using two different methods that lead to similar conclusions. Changes in the linear extension of the shell as a function of decreasing $\mathrm{pH}$ have been studied on both juveniles and adults of the Arctic pteropod Limacina helicina (Comeau et al. 2009, 2012; Lischka et al. 2011; Lischka and Riebesell 2012). Three studies tended to demonstrate a decrease in the linear extension of the shell (Comeau et al. 2009, 2012; Lischka et al. 2011), whereas one did not lead to conclusive results (Lischka and Riebesell 2012). The use of the radioelement ${ }^{45} \mathrm{Ca}$ has also allowed for the quantification of the effect of ocean acidification on gross calcification. The two studies that have used this approach also showed a decrease in calcification as a function of decreasing $\mathrm{pH}$ at both ambient (Comeau et al. 2009, 2010b) and elevated (Comeau et al. 2010b) temperature. The relationship between calcification and the saturation state of aragonite $\left(\Omega_{\mathrm{a}}\right)$ was best described by a logarithmic function, with no gross calcification at $\Omega_{\mathrm{a}}$ below 0.7 (Comeau et al. 2010b).

The response of calcification to global environmental change is much less documented in temperate pteropods. Comeau et al. (2010a) maintained eggs and larvae of the Mediterranean species Cavolinia inflexa at three $\mathrm{pH}$ conditions (control, -0.3 and $-0.6 \mathrm{pH}$ unit) and showed that individuals incubated at intermediate $\mathrm{pH}$ exhibited lower extension of the shell and various malformations compared with the control, whereas larvae grown at the lowest $\mathrm{pH}$ (in an undersaturated condition with respect to aragonite) were shell-less but viable.

The effects of ocean acidification on processes other than calcification have received less attention. Studies on respiration rates have led to contradictory results on polar species. In L. helicina antarctica, it decreases by $25 \%$ at $789 \mu \mathrm{atm}$ and $-1.86{ }^{\circ} \mathrm{C}$ (ambient temperature) compared with control conditions (Fabry et al. 2008), whereas in the Arctic species L. helicina, respiration increased linearly as a function of decreasing $\mathrm{pH}$ at elevated temperature (no significant effect of $\mathrm{pH}$ was found at in situ temperature, Comeau et al. 2010b). Recently, it also has been shown that L. helicina antarctica demonstrates variable responses to increasing $p \mathrm{CO}_{2}$ in response to phytoplankton concentration (Seibel et al. 2012). When phytoplankton was available in high concentration, the authors measured a decrease in respiration with increasing $p \mathrm{CO}_{2}$, whereas no effect of the $p \mathrm{CO}_{2}$ was measured on food-limited organisms. The effects of elevated $\mathrm{CO}_{2}$ on respiration and excretion have also been investigated in five subtropical and tropical pteropods (Maas et al. 2012). Four of the species go through an oxygen minimum zone (OMZ) during their vertical migration. Their respiration and excretion were unaffected by increasing $\mathrm{CO}_{2}$, but these processes were depressed by elevated $\mathrm{CO}_{2}$ in the species that did not migrate through an OMZ. In addition to respiration, other parameters such as the rate of gut clearance and swimming activity have been investigated. Gut clearance rates were not significantly affected by $\mathrm{CO}_{2}$ at both ambient and elevated temperature in L. helicina (Comeau et al. 2010b). Swimming activity of $L$. retroversa was only negatively affected by elevated $\mathrm{CO}_{2}$ combined with a decrease in salinity (Manno et al. 2012). These results suggest that the response of pteropods to ocean acidification depends on the phenotypic history of a given species, and on the combination of stressors such as temperature, salinity and $\mathrm{CO}_{2}$.

In order to simulate the future of pteropod populations, Comeau et al. (2011) used models that combine empirical data on the relationship between gross calcification and aragonite saturation state, projections of aragonite saturation state and data on pteropods' diurnal migrations. Calcification of both temperate and polar pteropods is expected to significantly decline in the future. Arctic pteropods are expected to be the most affected, with model projections suggesting that L. helicina will not be able to precipitate any calcium carbonate in much of the Arctic by 2100 under the IPCC SRES A2 scenario. The effects of declining calcification on pteropod physiology remain unknown and could lead to unexpected results such as "naked" pteropods (Comeau et al. 2010a). Nevertheless, the survival of such organisms in the natural environment seems highly improbable, and the decline of pteropod populations very likely. Declining pteropod populations might have severe impacts on the species that depend upon them as a food resource, but data on this issue are not available and represent a critical research challenge. One model study demonstrating this effect (Aydin et al. 2005) 
Table 4 Summary of the impacts of ocean acidification on pteropods (larvae and juveniles/adults)

\begin{tabular}{|c|c|c|c|c|}
\hline \multirow{3}{*}{$\begin{array}{l}\text { Author/acclimation time } \\
\text { Species }\end{array}$} & \multirow[t]{3}{*}{ Process } & \multirow[t]{3}{*}{ Impact } & \multicolumn{2}{|c|}{$\mathrm{pH}$ (unit decrease from ambient) } \\
\hline & & & Projected 2100 & Projected 2300 \\
\hline & & & $-0.3-0.4$ & $-0.5-0.6$ \\
\hline
\end{tabular}

Bednaršek et al. (2012a; 14 days)

Limacina helicina, Clio

Pyramidata

Bednaršek et al. (2012b; 4-14 days)

Limacina helicina

Comeau et al. (2009; 5 days)

Limacina helicina

Comeau et al. (2010a; 13 days)

Cavolinia inflexa (larvae-juvenile)

Comeau et al. (2010b; 3 days)

Limacina helicina

Comeau et al. (2012; 8 days)

Limacina helicina (juvenile)

Lischka et al. (2011; 29 days)

Limacina helicina (juvenile)

Lischka and Riebesell (2012;

7 days)

Limacina helicina (juvenile)

Limacina retroversa (juvenile)

Maas et al. (2012; 18 h)

Hyalocylis striata, Clio pyramidata, Cavolinia longirostris, Creseis virgula

Diacria quadridentata

Manno et al. (2012; 8 days) Limacina retroversa
Shell degradation $\uparrow$

Shell degradation

Calcification

Shell normality

Size

Calcification

Respiration $_{\text {(ambient }}$

temperature)

Respiration $_{\text {(high }}$

temperature)

Gut clearance

Calcification $\downarrow$

Survival =

Shell degradation

Survival

Shell degradation

Shell growth

Survival $_{(\text {ambient }}=$

temperature)

Survival $_{(\text {high }}$

temperature)

Shell degradation

Survival $_{(a m b i e n t}$

temperature)

Survival $_{(\text {high }}$

temperature)

Shell degradation

Respiration

$=$

Excretion

Respiration

Excretion

Survival $_{\text {(only when }} \downarrow$

combined with

freshening)

Shell degradation 
Table 4 continued

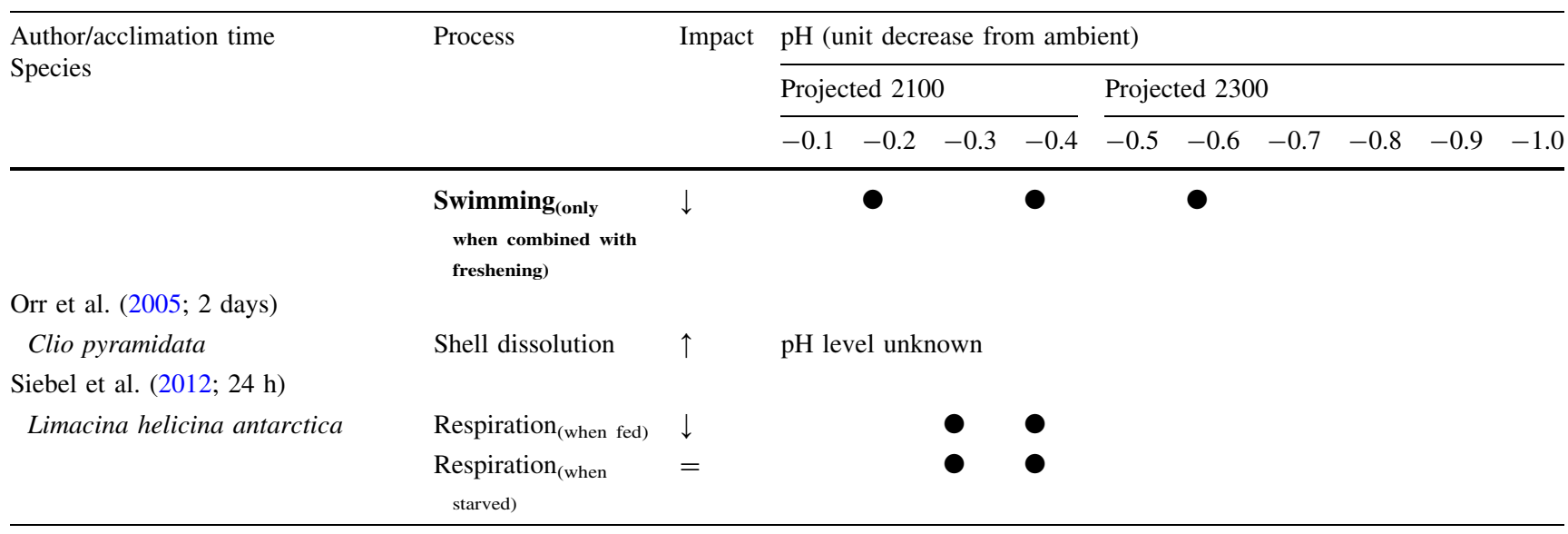

In bold, studies considering more than one stressor (e.g. temperature, salinity, food availability, etc.). Open and full circles refer to not significant and significant effects, respectively

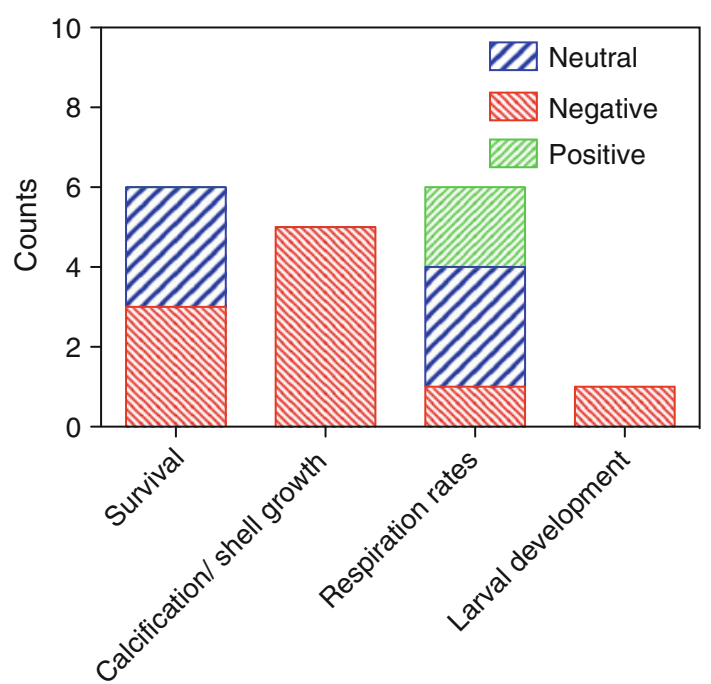

Fig. 6 Summary of the impacts of ocean acidification on pteropods for studies considering a $\mathrm{pH}$ decrease lower than 0.4 unit

predicted that a $10 \%$ drop in pteropod abundance in the subarctic North Pacific could lead to a $20 \%$ drop in pink salmon body weight (Foy, personal communication).

\section{Field studies}

In the marine environment, shelled molluscs colonized very diverse habitats with a wide range of physicochemical and biological conditions. They can be found and are in some cases the dominant species in naturally $\mathrm{CO}_{2}$-rich areas near deep submarine volcanoes or shallow-water volcanic vents and in estuaries. In deep and shallow volcanic systems, reduced $\mathrm{pH}$ levels are attributed to high levels of $\mathrm{CO}_{2}$ in the hydrothermal fluids and to $\mathrm{CO}_{2}$ gas bubbles diffusing from the vents. In estuaries, the $\mathrm{pH}$ levels are tightly linked to salinity changes and metabolic processes. Reduced salinities associated with freshwater inputs or rain events are linked to reduced water $\mathrm{pH}$. In deeper water layers in the open ocean or in deeper layers of estuaries, oxygen minimum zones can form from respiration associated with the decomposition of sedimentary organic matter. Seasonal decreases in $\mathrm{pH}$ usually occur during warm summer periods, when hypoxia and anoxia develop in bottom water layers. The upwelling of $\mathrm{CO}_{2-}$ enriched waters from oxygen minimum zones also results in low $\mathrm{pH}$ conditions in estuarine and coastal waters. Estuarine acidification can also result from increasing eutrophication and regional changes in land use (Dove and Sammut 2007). In spite of high $\mathrm{pH}$ fluctuations and simultaneous effects of other physicochemical variables such as temperature, chemical element content (hydrogen sulphide or arsenic), dissolved oxygen levels or sediment composition, these naturally $\mathrm{CO}_{2}$-rich habitats can serve as analogues for future more acidic ecosystems. Most of the studies conducted in these "natural laboratories" report deleterious effects of increased $\mathrm{CO}_{2}$ levels (low seawater $\mathrm{pH})$ on shelled molluscs, including decreased settlement and growth rates and increased shell dissolution and mortality.

In deep submarine volcanoes where the mussels Bathymodiolus brevior develop, liquid $\mathrm{CO}_{2}$ from hydrothermal vents can decrease $\mathrm{pH}_{\mathrm{NBS}}$ (National Bureau of Standards scale) down to 5.4 (Tunnicliffe et al. 2009). In such low $\mathrm{pH}$ conditions (from $\mathrm{pH}_{\mathrm{NBS}} 5.4$ to 7.3 ), shell thickness and daily shell growth increments of $B$. brevior are reduced in comparison with those of mussels living in higher $\mathrm{pH}$ conditions (from $\mathrm{pH}_{\mathrm{NBS}} 7.8$ to 8.4 ). Their survival and the precipitation of their shell in this low-pH environment is remarkable and is suggested to be possible only for mussels with an intact periostracum protecting 
their shell as damage of this protective organic layer can lead to complete dissolution of their shells. The authors noted that since the shells of these mussels are much weaker, the mussel populations are much less protected against predators. Fortunately, those predators (crabs) are absent from the submarine low $\mathrm{pH}$ site. Another explanation for the survival of these mussels in such an acidic environment is the presence of symbiotic sulphide-oxidizing bacteria, providing enough energy to cope with the suboptimal conditions. These deep-sea bivalves appear to be quite resistant to strong acidosis as revealed by the study of Hammer et al. (2011) where deep-sea clams respiration and excretion rates were not affected by a very strong $\mathrm{pH}$ decrease $(-1.8 \mathrm{pH}$ unit) over 4-day exposure. In shallower waters, Karlen et al. (2010) focused on the influence of $\mathrm{pH}$, along with other vent-related factors such as arsenic, temperature and sediment characteristics, on the benthic macrofauna near a hydrothermal vent (Ambitle Island, Papua New Guinea) where $\mathrm{pH}$ increases with distance from the vent. They found that the change in macrofaunal composition (abundance, species richness and diversity) is strongly correlated with $\mathrm{pH}$, relative to other environmental parameters. Shelled molluscs were completely absent close to the vent at $\mathrm{pH} 6.2$ ( $\mathrm{pH}$ scale unknown) and showed a strong trend of increasing abundance with increasing $\mathrm{pH}$, being rare at $\mathrm{pH} 6.8$ and abundant at $\mathrm{pH}$ 7.2. Some shallowwater volcanic vents such as the $\mathrm{CO}_{2}$ vent off Ischia Island, Italy, are at ambient seawater temperature and lack toxic compounds. The release of $\mathrm{CO}_{2}$ lowers $\mathrm{pH}$ to less than 7 (Hall-Spencer et al. 2008). At this site, reduced pH has caused a decrease in the abundance of calcareous organisms including shelled molluscs. Those found show marked shell dissolution near the vent. Rodolfo-Metalpa et al. (2011) showed through a transplantation experiment carried out at this site that shelled molluscs are able to calcify and grow at even faster than normal rates when exposed to the high $\mathrm{CO}_{2}$ levels but that they remain at risk due to the dissolution of exposed shells that occurs as $\mathrm{pH}$ levels fall. As reported for mussels surrounding submarine volcanoes, the authors also found that an intact periostracum plays a major role in protecting the shells from acidified sea water, limiting dissolution and allowing organisms to calcify. Cigliano et al. (2010) placed artificial collectors along a pH gradient, ranging from $\mathrm{pH}_{\mathrm{T}}$ (total scale) 7.08-8.15, created by $\mathrm{CO}_{2}$ vents off the coast of Ischia in the Tyrrhenian Sea, Italy. After 1 month, they found a significant reduction in the recruitment of a range of bivalve and gastropod species as the seawater $\mathrm{pH}_{\mathrm{T}}$ decreased from normal (8.09-8.15) to low (7.08-7.79), suggesting that the settlement of benthic shelled molluscs is highly impacted by acidification. Juveniles of the gastropod snails Osilinus turbinata and Patella caerulea were absent from sites with very low $\mathrm{pH}$ $\left(\mathrm{pH}_{\mathrm{T}} \leq 7.4\right)$, but were present at the normal $\mathrm{pH}$ site $\left(\mathrm{pH}_{\mathrm{T}}\right.$
8.09-8.15; Hall-Spencer et al. 2008). Furthermore, the shell strength of adult snails Hexaplex trunculus and Cerithium vulgatum was reduced in acidic sea water.

In estuaries, although salinity changes and low dissolved oxygen levels are often regarded as major parameters affecting the distribution and physiological performance of estuarine species, recent studies indicate that $\mathrm{pH}$ also is a very important parameter. Ringwood and Keppler (2002) showed that the growth rate of juvenile clams, M. mercenaria, is tightly linked to $\mathrm{pH}$ conditions, being significantly reduced when $\mathrm{pH}$ levels fell below 7.5 (scale unknown) in comparison with higher $\mathrm{pH}$ conditions. In the Sungai Brunei estuary, Marshall et al. (2008) observed that shell dissolution in populations of the gastropod whelk, Thais gradata, correlated negatively with $\mathrm{pH}$. The shell length of these gastropods increased progressively in a rising $\mathrm{pH}$ gradient from land to sea (from a mean $\mathrm{pH}_{\mathrm{NBS}}$ of 6.8 to 8.02). In some cases, estuaries are also subject to increased acid loading from acid sulphate soils (ASS). Recently, Amaral et al. (2012) have reported on the impacts of a 70-day transplantation experiment to decreased $\mathrm{pH}$ levels ( -0.8 to $-1.9 \mathrm{pH}$ unit) on 6-month-old oysters (Saccostrea glomerata). These juveniles appeared very resistant, as survival was not impacted by the extremely low $\mathrm{pH}$ levels. However, they exhibited significantly lower growth rates than specimens maintained at the relatively high $\mathrm{pH}$ sites. In contrast, Dove and Sammut (2007) reported higher mortality in the small Sydney rock oysters, Saccostrea glomerata, caused by acid-induced shell degradation (perforated valves) at sites impacted by ASS compared with reference sites. The decomposition of sedimentary organic matter in estuaries resulting in increasing $\mathrm{CO}_{2}$ levels and subsequent undersaturation of sediment carbonates is another process that can alter the recruitment and survival of just-settled shelled molluscs. Green et al. (2004) showed increased mortality rates of juvenile $M$. mercenaria in undersaturated sediments, and when adding ground clam shells to the sediment in order to increase saturation state, Green et al. (2009) reported a higher recruitment of these juveniles in $\mathrm{CaCO}_{3}$ buffered relative to unbuffered sediments.

Conversely, a limited number of species may be adapted to life in naturally $\mathrm{CO}_{2}$-enriched sites. In Kiel Fjord, naturally acidified due to the upwelling of $\mathrm{CO}_{2}$-rich waters, a recent study (Thomsen et al. 2010) showed that the benthic compartment was dominated by the blue mussel M. edulis and that their recruitment period in summer coincides with the highest annual $p \mathrm{CO}_{2}$ levels $(\sim 1,000 \mu \mathrm{atm})$. Despite elevated $p \mathrm{CO}_{2}$ levels, these organisms are able to maintain control rates of somatic and shell growth, supported by ample food supply (section "Synergistic impacts").

Beyond the effects of decreasing $\mathrm{pH}$ in these naturally $\mathrm{CO}_{2}$-rich habitats, there is a lack of knowledge on the 
long-term effects of decreased $\mathrm{pH}$. To date, only the study of Wootton et al. (2008) reports on the effects of long-term ( 8 years) decreasing $\mathrm{pH}$ on benthic species, linked to a decline in the abundance and mean size of M. galloprovincialis and M. trossulus, at Tatoosh Island (Eastern Pacific).

Change in shelled mollusc skeleton size and composition with latitudes is also a way to understand the response of shelled molluscs to changes in $\mathrm{CaCO}_{3}$ saturation state. In particular, mollusc shell mass, thickness, and inorganic content (a proxy for skeletal $\mathrm{CaCO}_{3}$ ) have been found to decrease with latitude according to the general trend of decrease in $\mathrm{CaCO}_{3}$ saturation state from the tropics to the poles (Watson et al. 2012a).

Regarding pteropods, a clear trend in population dynamics that could be attributed to ocean acidification has not yet been detected. Analysis of the 1951-2008 time series of zooplankton in Californian coastal waters did not provide evidence for declines in the abundance of shelled pteropods (Ohman et al. 2009) despite a measurable reduction in aragonite saturation state in the same region (Feely et al. 2008). Mackas and Galbraith (2011) documented a decline in the abundance of Limacina sp. around Vancouver Island, but also noted a large increase in the abundance of Clio sp. Indications of decreasing shell thickness and increasing shell porosity over the last 50 years in Creseis acicula and Diacavolinia longirostris have been reported (Roger et al. 2012). The authors attribute this phenomenon to a $10 \%$ decrease in aragonite saturation state in the Australian tropical water during the same period. The use of sediment traps also is useful to investigate the response of pteropod to global change, but so far, their use has not led to conclusive results (Roberts et al. 2011). Recently, Bednaršek et al. (2012b) have shown that shells of live pteropods collected in the Southern Ocean at $200 \mathrm{~m}$ depth, where the water is undersaturated with respect to aragonite, exhibited severe signs of dissolution. This last result is alarmist as it demonstrates that the observations previously made under laboratory conditions mimicking the future ocean (e.g. Lischka et al. 2011) are presently happening in some areas of the ocean.

\section{Gaps in our understanding}

Environmental conditions versus laboratory conditions

Marine shelled molluscs are particularly abundant in coastal regions where $\mathrm{pH}$ (and $p \mathrm{CO}_{2}$ ) is strongly influenced by biogeochemical and hydrological activities, resulting in significant daily and/or seasonal variations (e.g. Provoost et al. 2010). While the analyses of surface water $\mathrm{pH}$ datasets in the open ocean reveal a clear and linear decrease in $\mathrm{pH}$ in the last few decades of $0.0014-0.0019$ pH unit per year (Orr 2011), the few available datasets for the coastal ocean suggest more complicated $\mathrm{pH}$ trends. Borges and Gypens (2010) modelled changes in $\mathrm{pH}$ in the Belgian coastal zone during the last decades. They suggested that changes in nutrient delivery by rivers had a stronger effect on the carbonate chemistry than ocean acidification. While these authors modelled a $\mathrm{pH}$ increase between the 1950s and 1990 as a response to increasing rates of primary production, they suggested that the decrease in nutrient loading since 1990 and the associated shift in the metabolic balance from net autotrophy to net heterotrophy could be responsible for a significant decrease in $\mathrm{pH}$ during that period. This has recently been confirmed by Provoost et al. (2010) based on the analysis of a $\sim 30$ year $\mathrm{pH}$ dataset in the Dutch coastal zone. All locations, but one, studied by these authors showed a $\mathrm{pH}$ decrease since the 1990s of $\sim 0.02 \mathrm{pH}$ unit per year, a rate which is one order of magnitude larger than in the open ocean. This is consistent with data reported by Wootton et al. (2008) on the Washington shelf which show a pH decline of $\sim 0.045$ unit per year between 2000 and 2008. Provoost et al. (2010) concluded that changes in nutrient availability and the ensuing changes in ecosystem metabolism of the Dutch coastal zone are most likely responsible for the trend that they observed. As mentioned by Borges and Gypens (2010), the nutrient regulation policies that have been enforced in many industrial countries in recent years have not yet been implemented in developing countries where eutrophication will likely continue to increase in coming decades, potentially masking the effects of ocean acidification. Nevertheless, surface water eutrophication can lead to the development of hypoxia and acidification in subsurface waters as a consequence of the microbial consumption of the enhanced surface organic matter production. This has recently been shown by Cai et al. (2011), through model simulations based on data collected in the northern Gulf of Mexico and the East China Sea. In these regions, a pH decrease of 0.45 unit in subpycnocline waters since pre-industrial times has been modelled, much higher than the 0.1 unit decline estimated for the global ocean. Cai et al. (2011) further suggested that this $\mathrm{pH}$ drop was greater than that expected from eutrophication and ocean acidification alone, as a consequence of the decreased buffering capacity of these $\mathrm{CO}_{2}$-enriched waters.

Furthermore, in some coastal areas, the episodic or permanent input of low $\mathrm{pH}$ water from rivers (Salisbury et al. 2008) and from the upwelling of $\mathrm{CO}_{2}$ rich waters (Feely et al. 2008; Thomsen et al. 2010) can generate high surface $p \mathrm{CO}_{2}$ levels. Feely et al. (2008) have noticed that even though seasonal upwelling of aragonite (one of the most soluble metastable form of calcium carbonate)- 
undersaturated waters on the northern California shelf is a natural feature, the uptake of anthropogenic $\mathrm{CO}_{2}$ has increased the areal extent of the affected area. This phenomenon has recently raised serious concerns about its potential effect on organisms such as bivalves. A dramatic increase in larval mortality in hatcheries of the northwest coast of the USA and poor larval recruitment success in the wild appear to be connected to ocean acidification (Barton et al. 2012).

Very few studies focusing on the effect of ocean acidification on shelled molluscs actually report on the level and on the variations in $\mathrm{pH}$ in the ecosystem the organisms were taken from (e.g. Thomsen et al. 2010). This is very critical since, as it will be developed in section "Acclimation and adaptation potential", resistance to elevated $\mathrm{CO}_{2}$ could be dependent on the environmental regime with populations of the same shelled mollusc species being already genetically adapted to low $\mathrm{pH}$ conditions. Furthermore, all studies to date consider stable $\mathrm{pH}$ conditions although, as mentioned previously, large daily and/or seasonal variations in $\mathrm{pH}$ are common features of coastal sites (Hofmann et al. 2011). For instance, Provoost et al. (2010) showed that, while the mean seasonal amplitude of nearshore stations of the Dutch coastal zone could be as high as $\sim 0.5 \mathrm{pH}$ unit, offshore stations displayed much lower variations with a mean seasonal amplitude of max. $0.1 \mathrm{pH}$ unit. The growth of shelled molluscs is not a constant process over an annual cycle, with relatively marked seasonal patterns in instantaneous growth rates as a consequence of variable temperature, food availability and predation pressure. For instance, in the Dutch coastal zone, the period of positive growth in spring (Cardoso et al. 2006) coincides with relatively high $\mathrm{pH}$ levels in these areas, as a consequence of high primary production rates (Provoost et al. 2010). The same is true with respect to temperature; organisms show positive performances during periods when temperatures are within their thermal range. This may allow them to tolerate wider ambient $\mathrm{CO}_{2}$ oscillations than when exposed to constant extreme temperatures. It is, therefore, of the utmost importance to reproduce in the laboratory the conditions, including their variability, at which the organisms are exposed in the field. A detailed discussion on this issue can be found in McElhany and Shallin Busch (2012; this issue). Finally, Gazeau et al. (2011) have shown that, during the first 3 days of development, oyster larvae appeared more sensitive to a decrease in carbonate ion concentrations than to a modification of $\mathrm{pH}$ itself. It is therefore of the utmost importance to carefully mimic, in addition to $\mathrm{pH}$, the alkalinity levels experienced by the organisms as well as their spatial and temporal variability that could be, in some cases, very significant (Borges et al. 2006; Yates and Halley 2006).
Synergistic impacts

In many places around the world, wild shelled mollusc populations have been declining in the last century as a response to human activities. The causes are multiple and include habitat destruction and overfishing (Rothschild et al. 1994; Airoldi and Beck 2007), bottom anoxia (Bishop et al. 2006; Peperzak and Poelman 2008), toxic algal blooms (May et al. 2010), increases in pathogens (Sindermann 1990) and contaminants (Pipe and Coles 1995) and introduction of exotic species (Harvell et al. 1999).

Ocean acidification may pose additional, potentially serious consequences for the success and survival of many shelled mollusc species, particularly for bivalves and gastropods. Increases in ocean $p \mathrm{CO}_{2}$ levels will be accompanied by increases in ocean temperature $\left(2-6{ }^{\circ} \mathrm{C}\right.$; Caldeira and Wickett 2003). In environments already experiencing suboptimal environmental conditions such as fluctuating salinity (i.e. estuarine habitats), reduced oxygen levels (hypoxia) or food limitation, ocean acidification may act synergistically to push organisms and ecosystems past their threshold limits. Despite this, there are very few studies that have considered the impacts of ocean acidification in synergy with other environmental stressors (see Fig. 7a). Studies on the synergistic impact of ocean acidification and ocean warming on marine phyla other than molluscs have led to two apparently contradictory sets of observations. First, the effects of ocean acidification are exacerbated in the presence of elevated temperature (Reynaud et al. 2003; Metzger et al. 2007; Anthony et al. 2008; Byrne et al. 2009; Gooding et al. 2009; Martin and Gattuso 2009; Munday et al. 2009). Second, the effects of ocean acidification are ameliorated in the presence of elevated temperature (Brennand et al. 2010). Higher temperature and higher salinity mitigated the impacts of reduced $\mathrm{pH}(-0.5 \mathrm{pH}$ unit) on the calcification of juvenile $C$. virginica (Waldbusser et al. 2011b). This contradiction is apparent because the effect of warming depends on the control temperature used and where it is placed in the thermal window and on the performance curve of a species (Pörtner and Farrell 2008). The first set starts from a temperature close to the optimum, warming causes a decrease in performance, with $\mathrm{CO}_{2}$ exacerbating the effects of warming. The second set starts from a temperature below the optimum, and warming then improves performance and resistance to $\mathrm{CO}_{2}$.

In the shelled mollusc species studied to date, most of the observations fall within the first set (Parker et al. 2009, 2010; Lannig et al. 2010; Hale et al. 2011; Lischka et al. 2011; Schalkhausser et al. 2012), in line with the hypothesis that $\mathrm{CO}_{2}$ causes a narrowing of thermal windows (Pörtner and Farrell 2008). These observations have ecosystem implications. A mesocosm experiment by Hale et al. (2011) looked at the impacts of ocean acidification 
and ocean warming on an intertidal marine community. They found that species diversity and abundance of the community was reduced by elevated $p \mathrm{CO}_{2}(-0.7$ and -1.3 $\mathrm{pH}$ unit), which was further reduced in the presence of elevated temperature $\left(+4{ }^{\circ} \mathrm{C}\right)$. Shelled molluscs experienced the greatest reduction in diversity and abundance.

Food availability will co-determine whether a species reaches its maximum performance and $\mathrm{CO}_{2}$ resistance. The vast majority of studies on the effects of ocean acidification on shelled molluscs have been performed under optimal food conditions. As we have already discussed, Melzner et al. (2011) showed that well-fed healthy animals display a higher capacity to compensate than starving individuals. It is critical to mimic the best we can the food conditions that the organisms experience in the field in order not to overestimate their $\mathrm{CO}_{2}$ (and other environmental disturbances) resistance capacities.

The results of these studies highlight the variability of responses that may exist when the pressures of ocean acidification are combined with other environmental stressors. The data suggest for several shelled molluscan species that ocean acidification combined with ocean warming may have even greater impacts than those documented for ocean acidification alone. This is the case, for instance, for the fluted giant clam (Tridacna squamosa) which showed much lower survival when low $\mathrm{pH}$ was combined with higher temperature (Watson et al. 2012b). In general, the number of available examples is limited which quantify these synergistic effects. The same holds for the interaction of ocean acidification with altered salinity, oxygen and food availability. It is vital that future studies assess the impacts of ocean acidification in synergy

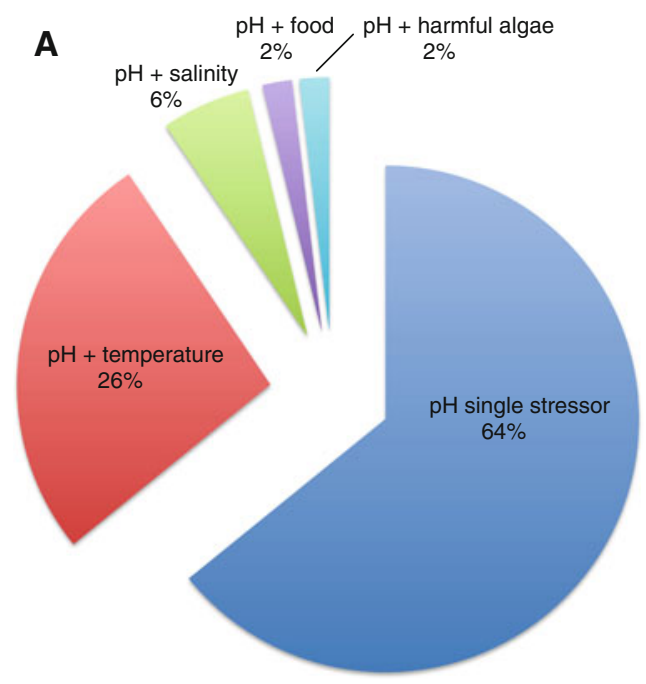

Fig. 7 a Percentage of studies considering $\mathrm{pH}$ as a single stressor and in combination with other environmentally relevant parameters. b Acclimation times considered in the studies focused on the effects with other environmental stressors before any generalized conclusions can be drawn.

Acclimation and adaptation potential

Another major obstacle for predicting future changes in marine and estuarine organisms and their ecosystems is our lack of knowledge of the potential for species acclimation or adaptation. Indeed, shelled molluscs have a life span, for many species, including those of importance in terms of economical value (oysters and mussels), covering several years. Yet, so far, very few studies have considered acclimation time of more than few months, with no study covering a full annual cycle (Fig. $7 \mathrm{~b}$ ). The available literature to date shows a variation in the response of shelled molluscs to elevated $p \mathrm{CO}_{2}$. In rare cases, studies have identified responses to ocean acidification, which reflect different sensitivities between populations of the same species. For example, Parker et al. (2011) found that shell growth of newly metamorphosed spat from populations of $S$. glomerata selectively bred in aquaculture (for faster growth and resistance to disease) was less responsive during acute exposure to elevated $p \mathrm{CO}_{2}$ (4 days; $-0.4 \mathrm{pH}$ unit) than that of the wild population. This indicates the potential for acclimation or evolutionary adaptation in a species.

If sensitive shelled mollusc species or their geographically distinct populations have the potential to acclimate or adapt, the question arises: which are the underlying mechanisms involved in acclimation or adaptation? Carryover effects may exist between life stages and, accordingly, generations. Carryover effects play a central role in

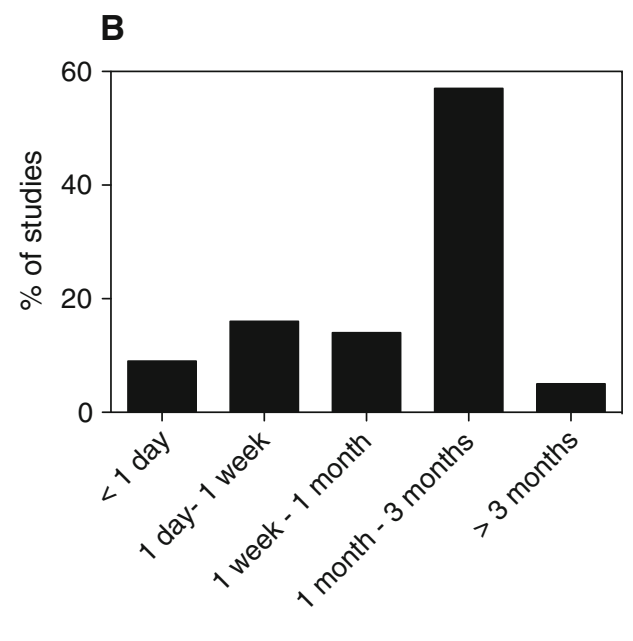

of ocean acidification on juvenile and adult shelled molluscs, following a $\mathrm{pH}$ decrease lower than 0.4 unit 
the evolutionary history of shelled molluscs and other marine organisms. In the oyster $C$. virginica, for example, the salinity that adults are held in during reproductive conditioning can determine the optimum salinity and salinity range of the resulting embryos and larvae (Davis 1958).

In the only study to directly consider the "link" between life-history stages of shelled molluscs during exposure to ocean acidification, Parker et al. (2012) reared adults and their offspring of a wild and selectively bred population of the Sydney rock oyster $S$. glomerata at elevated $p \mathrm{CO}_{2}$ of $860 \mu \mathrm{atm}(-0.3 \mathrm{pH}$ unit). They found that exposure of adults to elevated $\mathrm{CO}_{2}$ during reproductive conditioning had positive effects on the larvae, with larvae spawned from adults reared at elevated $\mathrm{CO}_{2}$ displaying larger sizes and faster rates of development, but similar survival as larvae spawned from adults reared at ambient/current $\mathrm{CO}_{2}$. The authors listed increased sizes of larvae due to greater maternal investment and higher SMR as two possible causes for the positive carryover effects experienced by larvae that were spawned from adults exposed to elevated $p \mathrm{CO}_{2}$. This study emphasizes the need to assess the effects of ocean acidification on the whole life cycle and across multiple generations of shelled molluscs and other marine and estuarine species. Recently, Sunday et al. (2011) have used a very original set-up aiming at estimating heritabilities and maternal effects (phenotypic and genotypic variations) at low $\mathrm{pH}$ and to use these estimates in order to simulate the species response to low $\mathrm{pH}$ over multiple generations. By applying these techniques to a sea urchin and a mussel, Sunday et al. (2011) demonstrated that, although the sea urchin species have a lower population turnover rate, its phenotypic and genotypic plasticity might lead to a faster adaptation to OA than for mussels. These types of studies would need to be generalized in the near future in order to allow a better understanding of the capacity for acclimation and/or adaptation of marine shelled molluscs over the next century.

\section{Conclusion}

Over the next decades, it is likely that ocean acidification will pose serious consequences for many marine and estuarine shelled molluscs. A comparison of the available literature to date suggests that while detrimental effects on adults remain uncertain, the most sensitive life-history stage seems to be the larvae, with a large majority of studies on this critical stage of development revealing negative effects.

Despite these obvious trends, our current understanding of the biological consequences of an acidifying ocean over the next century is still dominated by large uncertainties. This is because the majority of studies done to date have measured single-species responses on one stage in the life cycle, without considering the synergistic effects of other stressors (i.e. temperature, hypoxia, food concentration) and have not considered the potential for species to adapt, nor the underlying mechanisms responsible for adaptation or acclimation. In order to fully understand the consequences of ocean acidification at the population and ecosystem level, multi-generational and multi-stressor experiments on multiple species from geographically distinct locations are needed to assess the adaptive capacity of shelled mollusc species and the potential winners and losers in an acidifying ocean over the next century.

Acknowledgments This work was supported by the French programme PNEC (Programme national environnement côtier; Institut national des sciences de l'univers) and is a contribution to the "European Project on Ocean Acidification" (EPOCA) which received funding from the European Community's Seventh Framework Programme (FP7/2007-2013) under grant agreement no. 211384, to the "Mediterranean Sea Acidification in a changing climate" project (MedSeA) which received funding from the European Community's Seventh Framework Programme (FP7/2007-2013) under grant agreement no. 265103 and to the German "Biological Impact of Ocean Acidification (BIOACID)" project funded by the Federal Ministry of Education and Research (BMBF). We thank the editor and 2 anonymous reviewers for very constructive feedback.

\section{References}

Addadi L, Joester D, Nudelman F, Weiner S (2006) Mollusk shell formation: a source of new concepts for understanding biomineralization processes. Chemistry 12:981-987. doi:10.1002/chem. 200500980

Airoldi L, Beck MW (2007) Loss, status and trends for coastal marine habitats of Europe. Oceanography and marine biology, vol 45. CRC Press/Taylor \& Francis Group, Boca Raton, pp 345-405

Almada-Villela PC (1984) The effects of reduced salinity on the shell growth of small Mytilus edulis. J Mar Biol Assoc UK 64:171-182

Almada-Villela PC, Davenport J, Gruffydd LD (1982) The effects of temperature on the shell growth of young Mytilus edulis L. J Exp Mar Biol Ecol 59:275-288

Amaral V, Cabral H, Bishop M (2012) Moderate acidification affects growth but not survival of 6-month-old oysters. Aquat Ecol 46:119-127. doi:10.1007/s10452-011-9385-5

Anthony KRN, Kline DI, Diaz-Pulido G, Dove S, Hoegh-Guldberg O (2008) Ocean acidification causes bleaching and productivity loss in coral reef builders. Proc Natl Acad Sci USA 105:17442-17446

Asmus RM, Asmus H (1991) Mussel beds-limiting or promoting phytoplankton. J Exp Mar Biol Ecol 148:215-232

Aydin KY, McFarlane GA, King JR, Megrey BA, Myers KW (2005) Linking oceanic food webs to coastal production and growth rates of Pacific salmon (Oncorhynchus spp.), using models on three scales. Deep Sea Res Part II 52:757-780

Bamber RN (1987) The effects of acidic sea water on young carpetshell clams Venerupsis desussata (L.) (Mollusca: Veneracea). J Exp Mar Biol Ecol 108:241-260 
Bamber RN (1990) The effects of acidic seawater on 3 species of lamellibranch mollusc. J Exp Mar Biol Ecol 143:181-191

Barnes RD (1974) Invertebrate Zoology, 3rd edn. W.B. Saunders Company, Philadelphia, London, Toronto

Barton A, Hales B, Waldbusser GG, Langdon C, Feely RA (2012) The Pacific oyster, Crassostrea gigas, shows negative correlation to naturally elevated carbon dioxide levels: implications for near-term ocean acidification effects. Limnol Oceanogr 57:698-710. doi:10.4319/lo.2012.57.3.0698

Bayne BL, Hawkins AJS (1992) Ecological and physiological aspects of herbivory in benthic suspension-feeding molluscs. In: John DM, Hawkins SJ, Price JH (eds) Plant-animal interactions in the marine benthos. Clarendon Press, Oxford, pp 265-288

Bechmann RK, Taban IC, Westerlund S, Godal BF, Arnberg M, Vingen S, Ingvarsdottir A, Baussant T (2011) Effects of ocean acidification on early life stages of shrimp (Pandalus borealis) and mussel (Mytilus edulis). J Toxicol Environ Health Part A 74:424-438. doi:10.1080/15287394.2011.550460

Bednaršek N, Tarling GA, Bakker DCE, Fielding S, Cohen A, Kuzirian A, McCorkle D, Lézé B, Montagna R (2012a) Description and quantification of pteropod shell dissolution: a sensitive bioindicator of ocean acidification. Glob Chang Biol 18:2378-2388. doi:10.1111/j.1365-2486.2012.02668.x

Bednaršek N, Tarling GA, Bakker DCE, Fielding S, Jones EM, Venables HJ, Ward P, Kuzirian A, Leze B, Feely RA, Murphy EJ (2012b) Extensive dissolution of live pteropods in the Southern Ocean. Nat Geosci 5:881-885. doi:10.1038/ngeo1635

Beesley A, Lowe DM, Pascoe CK, Widdicombe S (2008) Effects of $\mathrm{CO}_{2}$ induced seawater acidification on the health of Mytilus edulis. Clim Res 37:215-225

Beniash E, Ivanina A, Lieb NS, Kurochkin I, Sokolova IM (2010) Elevated level of carbon dioxide affects metabolism and shell formation in oysters Crassostrea virginica. Mar Ecol Prog Ser 419:95-108. doi:10.3354/meps08841

Berge JA, Bjerkeng B, Pettersen O, Schaanning MT, Oxnevad S (2006) Effects of increased sea water concentrations of $\mathrm{CO}_{2}$ on growth of the bivalve Mytilus edulis L. Chemosphere 62:681-687

Berger WH (1978) Deep-sea carbonate-pteropod distribution and aragonite compensation depth. Deep Sea Res 25:447-452

Berner RA (1977) Sedimentation and dissolution of pteropods in the ocean. In: Andersen NR, Malahoff A (eds) The fate of fossil fuel $\mathrm{CO}_{2}$ in the oceans. Plenum Press, New York, pp 243-260

Berner RA, Honjo S (1981) Pelagic sedimentation of aragonite: its geochemical significance. Science 211:940-942

Beukema JJ (1980) Calcimass and carbonate production by mollusks on the tidal flats in the Dutch Wadden Sea. I. The Tellinid bivalve Macoma balthica. Neth J Sea Res 14:323-338

Beukema JJ (1982) Calcimass and carbonate production by mollusks on the tidal flats in the Dutch Wadden Sea. II. The edible-cockle, Cerastoderma edule. Neth J Sea Res 15:391-405

Beukema JJ, Cadee GC (1999) An estimate of the sustainable rate of shell extraction from the Dutch Wadden Sea. J Appl Ecol 36:49-58

Bibby R, Cleall-Harding P, Rundle S, Widdicombe S, Spicer J (2007) Ocean acidification disrupts induced defences in the intertidal gastropod Littorina littorea. Biol Lett 3:699-701

Bibby R, Widdicombe S, Parry H, Spicer J, Pipe R (2008) Effects of ocean acidification on the immune response of the blue mussel Mytilus edulis. Aquat Biol 2:67-74

Bishop MJ, Powers SP, Porter HJ, Peterson CH (2006) Benthic biological effects of seasonal hypoxia in a eutrophic estuary predate rapid coastal development. Estuar Coast Shelf Sci 70:415-422. doi:10.1016/j.ecss.2006.06.031

Borges AV, Gypens N (2010) Carbonate chemistry in the coastal zone responds more strongly to eutrophication than to ocean acidification. Limnol Oceanogr 55:346-353
Borges AV, Schiettecatte L-S, Abril G, Delille B, Gazeau F (2006) Carbon dioxide in European coastal waters. Estuar Coast Shelf Sci 70:375-387

Boudry P, Collet B, Cornette F, Hervouet V, Bonhomme F (2002) High variance in reproductive success of the Pacific oyster (Crassostrea gigas, Thunberg) revealed by microsatellite-based parentage analysis of multifactorial crosses. Aquaculture 204:283-296. doi:10.1016/s0044-8486(01)00841-9

Brečević L, Nielsen AE (1989) Solubility of amorphous calcium carbonate. J Cryst Growth 98:504-510. doi:10.1016/0022-0248 (89) $90168-1$

Brennand HS, Soars N, Dworjanyn SA, Davis AR, Byrne M (2010) Impact of ocean warming and ocean acidification on larval development and calcification in the sea urchin Tripneustes gratilla. PLoS ONE 5:e11372. doi:10.1371/journal.pone.0011372

Byrne M (2011) Impact of ocean warming and ocean acidification on marine invertebrate life history stages: vulnerabilities and potential for persistence in a changing ocean. In: Gibson RN, Atkinson RJA, Gordon JDM (eds) Oceanography and marine biology: an annual review, vol 49, pp 1-42

Byrne M, Ho M, Selvakumaraswamy P, Nguyen HD, Dworjanyn SA, Davis AR (2009) Temperature, but not $\mathrm{pH}$, compromises sea urchin fertilisation and early development under near-future climate change scenarios. Proc R Soc B Biol Sci 276:1183-1888

Byrne M, Soars NA, Ho MA, Wong E, McElroy D, Selvakumaraswamy P, Dworjanyn SA, Davis AR (2010) Fertilization in a suite of coastal marine invertebrates from SE Australia is robust to near-future ocean warming and acidification. Mar Biol 157:2061-2069. doi:10.1007/s00227-010-1474-9

Byrne M, Ho M, Wong E, Soars NA, Selvakumaraswamy P, ShepardBrennand H, Dworjanyn SA, Davis AR (2011) Unshelled abalone and corrupted urchins: development of marine calcifiers in a changing ocean. Proc R Soc B Biol Sci 278:2376-2383. doi: 10.1098/rspb.2010.2404

Cai W-J, Hu X, Huang W-J, Murrell MC, Lehrter JC, Lohrenz SE, Chou W-C, Zhai W, Hollibaugh JT, Wang Y, Zhao P, Guo X, Gundersen K, Dai M, Gong G-C (2011) Acidification of subsurface coastal waters enhanced by eutrophication. Nat Geosci (advance online publication). http://www.nature.com/ngeo/journal/vaop/ncurrent/ abs/ngeo1297.html\#supplementary-information

Calabrese A, Davis HC (1966) The $\mathrm{pH}$ tolerance of embryos and larvae of Mercenaria mercenaria and Crassostrea virginica. Biol Bull 131:427-436

Caldeira K, Wickett ME (2003) Anthropogenic carbon and ocean pH. Nature 425:365

Cardoso JFMF, Witte JI, van der Veer HW (2006) Intra- and interspecies comparison of energy flow in bivalve species in Dutch coastal waters by means of the Dynamic Energy Budget (DEB) theory. J Sea Res 56:182-197

Castel J, Labourg PJ, Escaravage V, Auby I, Garcia ME (1989) Influence of seagrass beds and oyster parks on the abundance and biomass patterns of meiobenthos and macrobenthos in tidal flats. Estuar Coast Shelf Sci 28:71-85

Chapman AD (2009) Numbers of living species in Australia and the world, 2nd edn. Australian Government, Department of the Environment, Water, Heritage and the Arts, Canberra

Chauvaud L, Thompson JK, Cloern JE, Thouzeau G (2003) Clams as $\mathrm{CO}_{2}$ generators: the Potamocorbula amurensis example in San Francisco Bay. Limnol Oceanogr 48:2086-2092

Cigliano M, Gambi MC, Rodolfo-Metalpa R, Patti FP, Hall-Spencer JM (2010) Effects of ocean acidification on invertebrate settlement at volcanic $\mathrm{CO}_{2}$ vents. Mar Biol 157:2489-2502. doi: 10.1007/s00227-010-1513-6

Coen LD, Brumbaugh RD, Bushek D, Grizzle R, Luckenbach MW, Posey MH, Powers SP, Tolley SG (2007) Ecosystem services related to oyster restoration. Mar Ecol Prog Ser 341:303-307 
Comeau S, Gorsky G, Jeffree R, Teyssié JL, Gattuso J-P (2009) Key Arctic pelagic mollusc (Limacina helicina) threatened by ocean acidification. Biogeosciences 6:1877-1882

Comeau S, Gorsky G, Alliouane S, Gattuso JP (2010a) Larvae of the pteropod Cavolinia inflexa exposed to aragonite undersaturation are viable but shell-less. Mar Biol 157:2341-2345. doi:10.1007/ s00227-010-1493-6

Comeau S, Jeffree R, Teyssié J-L, Gattuso J-P (2010b) Response of the Arctic pteropod Limacina helicina to projected future environmental conditions. PLoS ONE 5:e11362

Comeau S, Gattuso J-P, Nisumaa A-M, Orr J (2011) Impact of aragonite saturation state changes on migratory pteropods. Proc R Soc B Biol Sci. doi:10.1098/rspb.2011.0910

Comeau S, Alliouane S, Gattuso JP (2012) Effects of ocean acidification on overwintering juvenile Arctic pteropods Limacina helicina. Mar Ecol Prog Ser 456:279-284. doi:10.3354/ meps09696

Crenshaw MA, Neff JM (1969) Decalcification at mantle-shell interface in molluscs. Am Zool 9:881-885

Crim RN, Sunday JM, Harley CDG (2011) Elevated seawater $\mathrm{CO}_{2}$ concentrations impair larval development and reduce larval survival in endangered northern abalone (Haliotis kamtschatkana). J Exp Mar Biol Ecol 400:272-277. doi:10.1016/j.jembe. 2011.02.002

Cummings V, Hewitt J, Van Rooyen A, Currie K, Beard S, Thrush S, Norkko J, Barr N, Heath P, Halliday NJ, Sedcole R, Gomez A, McGraw C, Metcalf V (2011) Ocean acidification at high latitudes: potential effects on functioning of the Antarctic bivalve Laternula elliptica. PLoS ONE 6:e16069

Davis HC (1958) Survival and growth of clam and oyster larvae at different salinities. Biol Bull 114:296-307

Davis HC, Calabrese A (1964) Combined effects of temperature and salinity on development of eggs and growth of larvae of $M$. mercenaria and $C$. virginica. Fish Bull Fish Wildl Serv 63:643-655

Deigweiher K, Bock C, Lucassen M, Pörtner HO (2009) Hypercapnia induced shifts in gill energy budgets of Antarctic notothenioids. J Comp Physiol B 180:347-359

Desrosiers RR, Desilets J, Dube F (1996) Early developmental events following fertilization in the giant scallop Placopecten magellanicus. Can J Fish Aquat Sci 53:1382-1392

Dickinson GH, Ivanina AV, Matoo OB, Pörtner HO, Lannig G, Bock C, Beniash E, Sokolova IM (2012) Interactive effects of salinity and elevated $\mathrm{CO}_{2}$ levels on juvenile Eastern oysters, Crassostrea virginica. J Exp Biol 215:29-43. doi:10.1242/jeb.061481

Dineshram R, Wong KKW, Xiao S, Yu Z, Qian PY, Thiyagarajan V (2012) Analysis of Pacific oyster larval proteome and its response to high- $\mathrm{CO}_{2}$. Mar Pollut Bull 64:2160-2167. doi: 10.1016/j.marpolbul.2012.07.043

Dove MC, Sammut J (2007) Impacts of estuarine acidification on survival and growth of Sydney rock oysters Saccostrea Glomerata (Gould 1850). J Shellfish Res 26:519-527

Dupont S, Dorey N, Thorndyke M (2010) What meta-analysis can tell us about vulnerability of marine biodiversity to ocean acidification? Estu Coast Shelf Sci 89:182-185. doi:10.1016/ j.ecss.2010.06.013

Ellis RP, Bersey J, Rundle SD, Hall-Spencer JM, Spicer JI (2009) Subtle but significant effects of $\mathrm{CO}_{2}$ acidified seawater on embryos of the intertidal snail, Littorina obtusata. Aquat Biol 5:41-48. doi:10.3354/ab00118

Eyster LS (1986) Shell inorganic composition and onset of shell mineralization during bivalve and gastropod embryogenesis. Biol Bull 170:211-231

Fabry VJ, Deuser WG (1991) Aragonite and magnesian calcite fluxes to the deep Sargasso Sea. Deep Sea Res Part A 38:713-728
Fabry VJ, Seibel BA, Feely RA, Orr JC (2008) Impacts of ocean acidification on marine fauna and ecosystem processes. ICES J Mar Sci 65:414-432

FAO (2008) Food and Agriculture Organization of the United Nations. Report of the FAO expert workshop on climate change implications for fisheries and aquaculture, Rome

Feely RA, Sabine CL, Hernandez-Ayon JM, Ianson D, Hales B (2008) Evidence for upwelling of corrosive "acidified" water onto the continental shelf. Science 320:1490-1492. doi: 10.1126/science. 1155676

Fernandez-Reiriz MJ, Range P, Alvarez-Salgado XA, Espinosa J, Labarta U (2012) Tolerance of juvenile Mytilus galloprovincialis to experimental seawater acidification. Mar Ecol Prog Ser 454:65-74. doi:10.3354/meps09660

Fernández-Reiriz MJ, Range P, Ávarez-Salgado XA, Labarta U (2011) Physiological energetics of juvenile clams Ruditapes decussatus in a high $\mathrm{CO}_{2}$ coastal ocean. Mar Ecol Prog Ser 433:97-105. doi:10.3354/meps09062

Frankignoulle M, Pichon M, Gattuso J-P (1995) Aquatic calcification as a source of carbon dioxide. In: Beran MA (ed) Carbon sequestration in the biosphere. Springer, Berlin, pp 266-271

Gaylord B, Hill TM, Sanford E, Lenz EA, Jacobs LA, Sato KN, Russell AD, Hettinger A (2011) Functional impacts of ocean acidification in an ecologically critical foundation species. J Exp Biol 214:2586-2594. doi:10.1242/jeb.055939

Gazeau F, Quiblier C, Jansen JM, Gattuso J-P, Middelburg JJ, Heip CHR (2007) Impact of elevated $\mathrm{CO}_{2}$ on shellfish calcification. Geophys Res Lett 34:L07603. doi:10.1029/2006GL028554

Gazeau F, Gattuso J-P, Dawber C, Pronker AE, Peene F, Peene J, Heip CHR, Middelburg JJ (2010) Effect of ocean acidification on the early life stages of the blue mussel Mytilus edulis. Biogeosciences 7:2051-2060

Gazeau F, Gattuso JP, Greaves M, Elderfield H, Peene J, Heip CHR, Middelburg JJ (2011) Effect of carbonate chemistry alteration on the early embryonic development of the Pacific oyster (Crassostrea gigas). PLoS ONE 6:e23010. doi:10.1371/journal.pone.0023010

Gooding RA, Harley CDG, Tang E (2009) Elevated water temperature and carbon dioxide concentration increase the growth of a keystone echinoderm. Proc Natl Acad Sci USA 106:9316-9321. doi:10.1073/pnas.0811143106

Gosling E (2003) Bivalve molluscs: biology, ecology and culture. Fishing News Books, Oxford

Grant J, Hatcher A, Scott DB, Pocklington P, Schafer CT, Winters GV (1995) A multidisciplinary approach to evaluating impacts of shellfish aquaculture on benthic communities. Estuaries 18:124-144. doi:10.2307/1352288

Green MA, Jones ME, Boudreau CL, Moore RL, Westman BA (2004) Dissolution mortality of juvenile bivalves in coastal marine deposits. Limnol Oceanogr 49:727-734

Green MA, Waldbusser GG, Reilly SL, Emerson K, O'Donnell S (2009) Death by dissolution: sediment saturation state as a mortality factor for juvenile bivalves. Limnol Oceanogr 54:1037-1047

Gutiérrez JL, Jones CG, Strayer DL, Iribarne OO (2003) Mollusks as ecosystem engineers: the role of shell production in aquatic habitats. Oikos 101:79-90

Hale R, Calosi P, McNeill L, Mieszkowska N, Widdicombe S (2011) Predicted levels of future ocean acidification and temperature rise could alter community structure and biodiversity in marine benthic communities. Oikos 120:661-674. doi:10.1111/j.16000706.2010.19469.x

Hall-Spencer JM, Rodolfo-Metalpa R, Martin S, Ransome E, Fine M, Turner SM, Rowley SJ, Tedesco D, Buia MC (2008) Volcanic carbon dioxide vents show ecosystem effects of ocean acidification. Nature 454:96-99. doi:10.1038/nature07051 
Hammer KM, Kristiansen E, Zachariassen KE (2011) Physiological effects of hypercapnia in the deep-sea bivalve Acesta excavata (Fabricius, 1779) (Bivalvia; Limidae). Mar Environ Res 72:135-142. doi:10.1016/j.marenvres.2011.07.002

Hankewich, Lessard (2006) Resurvey of northern abalone, Haliotis kamtschatkana, populations along the central coast of British Columbia, May 2006. Issue 2838 of Canadian manuscript report of fisheries and aquatic sciences. Fisheries \& Oceans Canada, Science Branch, Pacific Region, Pacific Biological Station, 2008, $41 \mathrm{pp}$

Harris JO, Maguire GB, Edwards SJ, Hindrum SM (1999) Effect of $\mathrm{pH}$ on growth rate, oxygen consumption rate, and histopathology of gill and kidney tissue for juvenile greenlip abalone, Haliotis laevigata Donovan and blacklip abalone, Haliotis rubra Leach. J Shellfish Res 18:611-619

Harvell CD, Kim K, Burkholder JM, Colwell RR, Epstein PR, Grimes DJ, Hofmann EE, Lipp EK, Osterhaus A, Overstreet RM, Porter JW, Smith GW, Vasta GR (1999) Review: marine ecologyemerging marine diseases-climate links and anthropogenic factors. Science 285:1505-1510

Havenhand JN, Schlegel P (2009) Near-future levels of ocean acidification do not affect sperm motility and fertilization kinetics in the oyster Crassostrea gigas. Biogeosciences 6:3009-3015

Havenhand JN, Buttler FR, Thorndyke MC, Williamson JE (2008) Near-future levels of ocean acidification reduce fertilization success in a sea urchin. Curr Biol 18:R651-R652. doi: 10.1016/j.cub.2008.06.015

Hayakaze E, Tanabe K (1999) Early larval shell development in mytilid bivalve Mytilus galloprovincialis. Venus 58:119-127

Hiebenthal C, Philipp ER, Eisenhauer A, Wahl M (2012) Effects of seawater $p \mathrm{CO}_{2}$ and temperature on shell growth, shell stability, condition and cellular stress of Western Baltic Sea Mytilus edulis (L.) and Arctica islandica (L.). Mar Biol 1-15. doi:10.1007/ s00227-012-2080-9

Hofmann GE, Smith JE, Johnson KS, Send U, Levin LA, Micheli F, Paytan A, Price NN, Peterson B, Takeshita Y, Matson PG, Crook ED, Kroeker KJ, Gambi MC, Rivest EB, Frieder CA, Yu PC, Martz TR (2011) High-frequency dynamics of ocean pH: a multi-ecosystem comparison. PLoS ONE 6. doi:10.1371/journal. pone. 0028983

Hüning A, Melzner F, Thomsen J, Gutowska M, Krämer L, Frickenhaus S, Rosenstiel P, Pörtner H-O, Philipp ER, Lucassen $M$ (2012) Impacts of seawater acidification on mantle gene expression patterns of the Baltic Sea blue mussel: implications for shell formation and energy metabolism. Mar Biol 1-17. doi: 10.1007/s00227-012-1930-9

Ip YK, Loong AM, Hiong KC, Wong WP, Chew SF, Reddy K, Sivaloganathan B, Ballantyne JS (2006) Light induces an increase in the $\mathrm{pH}$ of and a decrease in the ammonia concentration in the extrapallial fluid of the giant clam Tridacna squamosa. Phys Biochem Zool 79:656-664

Karlen DJ, Price RE, Pichler T, Garey JR (2010) Changes in benthic macrofauna associated with a shallow-water hydrothermal vent gradient in Papua New Guinea. Pac Sci 64:391-404. doi: 10.2984/64.3.391

Kawatani Y, Nishii T (1969) Effects of $\mathrm{pH}$ of culture water on the growth of the Japanese pearl oyster. Bull Jpn Soc Fish Sci 35:342-350

Kimura RYO, Takami H, Ono T, Onitsuka T, Nojiri Y (2011) Effects of elevated $\mathrm{pCO}_{2}$ on the early development of the commercially important gastropod, Ezo abalone Haliotis discus hannai. Fish Oceanogr 20:357-366. doi:10.1111/j.1365-2419.2011.00589.x

Kniprath E (1981) Ontogeny of the molluscan shell field-a review. Zool Scr 10:61-79

Knutzen J (1981) Effects of decreased pH on marine organisms. Mar Pollut Bull 12:25-29
Kurihara $\mathrm{H}$ (2008) Effects of $\mathrm{CO}_{2}$-driven ocean acidification on the early developmental stages of invertebrates. Mar Ecol Prog Ser 373:275-284. doi:10.3354/meps07802

Kurihara H, Kato S, Ishimatsu A (2007) Effects of increased seawater $\mathrm{CO}_{2}$ on early development of the oyster Crassostrea gigas. Aquat Biol 1:91-98

Kurihara H, Asai T, Kato S, Ishimatsu A (2008) Effects of elevated $\mathrm{pCO}_{2}$ on early development in the mussel Mytilus galloprovincialis. Aquat Biol 4:225-233. doi:10.3354/ab00109

Lalli CM, Gilmer R (1989) Pelagic snails. Stanford University Press, Stanford

Lannig G, Eilers S, Portner HO, Sokolova IM, Bock C (2010) Impact of ocean acidification on energy metabolism of oyster, Crassostrea gigas: changes in metabolic pathways and thermal response. Mar Drugs 8:2318-2339. doi:10.3390/md8082318

Lavrentyev PJ, Gardner WS, Yang LY (2000) Effects of the zebra mussel on nitrogen dynamics and the microbial community at the sediment-water interface. Aquat Microb Ecol 21:187-194

Lischka S, Riebesell U (2012) Synergistic effects of ocean acidification and warming on overwintering pteropods in the Arctic. Glob Chang Biol 18:3517-3528. doi:10.1111/gcb.12020

Lischka S, Büdenbender J, Boxhammer T, Riebesell U (2011) Impact of ocean acidification and elevated temperatures on early juveniles of the polar shelled pteropod Limacina helicina: mortality, shell degradation, and shell growth. Biogeosciences 8:919-932. doi:10.5194/bg-8-919-2011

Liu WG, He MX (2012) Effects of ocean acidification on the metabolic rates of three species of bivalve from southern coast of China. Chin J Oceanol Limnol 30:206-211. doi:10.1007/s00343012-1067-1

Loosanoff VL, Tommers FD (1947) Effect of low pH upon rate of water pumping of oysters, Ostrea virginica. Anat Rec 99:668-669

Lopez IR, Kalman J, Vale C, Blasco J (2010) Influence of sediment acidification on the bioaccumulation of metals in Ruditapes philippinarum. Environ Sci Pollut Res 17:1519-1528. doi: 10.1007/s11356-010-0338-7

Maas AE, Wishner KF, Seibel BA (2012) Metabolic suppression in thecosomatous pteropods as an effect of low temperature and hypoxia in the eastern tropical North Pacific. Mar Biol 159:1955-1967. doi:10.1007/s00227-012-1982-x

Mackas DL, Galbraith MD (2011) Pteropod time-series from the NE Pacific. ICES J Mar Sci. doi:10.1093/icesjms/fsr163

Malone PG, Dodd JR (1967) Temperature and salinity effects on calcification rate in Mytilus edulis and its paleoecological implications. Limnol Oceanogr 12:432-436

Manno C, Morata N, Primicerio R (2012) Limacina retroversa's response to combined effects of ocean acidification and sea water freshening. Estuar Coast Shelf Sci 113:163-171. doi: 10.1016/j.ecss.2012.07.019

Marchant HK, Calosi P, Spicer JI (2010) Short-term exposure to hypercapnia does not compromise feeding, acid-base balance or respiration of Patella vulgata but surprisingly is accompanied by radula damage. J Mar Biol Assoc UK 90:1379-1384. doi: $10.1017 / \mathrm{S} 0025315410000457$

Marin F, Luquet G (2004) Molluscan shell proteins. CR Palevol 3:469-492. doi:10.1016/j.crpv.2004.07.009

Marshall DJ, Santos JH, Leung KMY, Chak WH (2008) Correlations between gastropod shell dissolution and water chemical properties in a tropical estuary. Mar Environ Res 66:422-429. doi: 10.1016/j.marenvres.2008.07.003

Martin S, Gattuso JP (2009) Response of Mediterranean coralline algae to ocean acidification and elevated temperature. Glob Chang Biol 15:2089-2100. doi:10.1111/j.1365-2486.2009.01874.x

Martin S, Thouzeau G, Chauvaud L, Jean F, Guerin L, Clavier J (2006) Respiration, calcification, and excretion of the invasive 
slipper limpet, Crepidula fornicata L.: implications for carbon, carbonate, and nitrogen fluxes in affected areas. Limnol Oceanogr 51:1996-2007

Martin S, Thouzeau G, Richard M, Chauvaud L, Jean F, Clavier J (2007) Benthic community respiration in areas impacted by the invasive mollusk Crepidula fornicata. Mar Ecol Prog Ser 347:51-60

Matozzo V, Chinellato A, Munari M, Finos L, Bressan M, Marin MG (2012) First evidence of immunomodulation in bivalves under seawater acidification and increased temperature. PLoS ONE 7:e33820. doi:10.1371/journal.pone.0033820

May SP, Burkholder JM, Shumway SE, Hegaret H, Wikfors GH, Frank D (2010) Effects of the toxic dinoflagellate Alexandrium monilatum on survival, grazing and behavioral response of three ecologically important bivalve molluscs. Harmful Algae 9:281-293. doi:10.1016/j.hal.2009.11.005

McClintock JB, Angus RA, McDonald MR, Amsler CD, Catledge SA, Vohra YK (2009) Rapid dissolution of shells of weakly calcified Antarctic benthic macroorganisms indicates high vulnerability to ocean acidification. Antarct Sci 21:449-456. doi: $10.1017 /$ s0954102009990198

McElhany P, Shallin Busch D (2012) Appropriate $\mathrm{pCO}_{2}$ treatments in ocean acidification experiments. Mar Biol 1-6. doi:10.1007/ s00227-012-2052-0

Melzner F, Gutowska MA, Hu M, Stumpp M (2009) Acid-base regulatory capacity and associated proton extrusion mechanisms in marine invertebrates: an overview. Comp Biochem Physiol Mol Integr Physiol 153A:S80. doi:10.1016/j.cbpa.2009.04.056

Melzner F, Stange P, Trübenbach K, Thomsen J, Casties I, Panknin U, Gorb SN, Gutowska MA (2011) Food supply and seawater $\mathrm{pCO}_{2}$ impact calcification and internal shell dissolution in the blue mussel Mytilus edulis. PLoS ONE 6:e24223. doi:10.1371/ journal.pone.0024223

Metzger R, Sartoris FJ, Langenbuch M, Pörtner HO (2007) Influence of elevated $\mathrm{CO}_{2}$ concentrations on thermal tolerance of the edible crab Cancer pagurus. J Therm Biol 32:144-151

Michaelidis B, Ouzounis C, Paleras A, Portner HO (2005) Effects of long-term moderate hypercapnia on acid-base balance and growth rate in marine mussels Mytilus galloprovincialis. Mar Ecol Prog Ser 293:109-118

Miller DC, Geider RJ, MacIntyre HL (1996) Microphytobenthos: the ecological role of the "secret garden" of unvegetated, shallowwater marine habitats. 2. Role in sediment stability and shallowwater food webs. Estuaries 19:202-212

Miller AW, Reynolds AC, Sobrino C, Riedel GF (2009) Shellfish face uncertain future in high $\mathrm{CO}_{2}$ world: influence of acidification on oyster larvae calcification and growth in estuaries. PLoS ONE 4:e5661. doi:10.1371/journal.pone.0005661

Miyamoto H, Miyashita T, Okushima M, Nakano S, Morita T, Matsushiro A (1996) A carbonic anhydrase from the nacreous layer in oyster pearls. Proc Natl Acad Sci USA 93:9657-9660

Mount AS, Wheeler AP, Paradkar RP, Snider D (2004) Hemocytemediated shell mineralization in the Eastern oyster. Science 304:297-300

Munday PL, Crawley NE, Nilsson GE (2009) Interacting effects of elevated temperature and ocean acidification on the aerobic performance of coral reef fishes. Mar Ecol Prog Ser 388:235-242

Nassif N, Pinna N, Gehrke N, Antonietti M, Jager C, Colfen H (2005) Amorphous layer around aragonite platelets in nacre. Proc Natl Acad Sci USA 102:12653-12655. doi:10.1073/pnas.0502577102

Navarro JM, Torres R, Acuna K, Duarte C, Manriquez PH, Lardies M, Lagos NA, Vargas C, Aguilera V (2013) Impact of mediumterm exposure to elevated $\mathrm{pCO}_{2}$ levels on the physiological energetics of the mussel Mytilus chilensis. Chemosphere 90:1242-1248. doi:10.1016/j.chemosphere.2012.09.063
Newell RIE (2004) Ecosystem influences of natural and cultivated populations of suspension-feeding bivalve molluscs: a review. J Shellfish Res 23:51-61

Newell RIE, Koch EW (2004) Modeling seagrass density and distribution in response to changes in turbidity stemming from bivalve filtration and seagrass sediment stabilization. Estuaries 27:793-806

Nielsen MV (1988) The effect of temperature on the shell length growth of juvenile Mytilus edulis L. J Exp Mar Biol Ecol 123:227-234

Nienhuis S, Palmer AR, Harley CDG (2010) Elevated $\mathrm{CO}_{2}$ affects shell dissolution rate but not calcification rate in a marine snail. Proc R Soc B Biol Sci 277:2553-2558. doi:10.1098/rspb. 2010.0206

Norling P, Kautsky N (2007) Structural and functional effects of Mytilus edulis on diversity of associated species and ecosystem functioning. Mar Ecol Prog Ser 351:163-175

Ohman MD, Lavaniegos BE, Townsend AW (2009) Multi-decadal variations in calcareous holozooplankton in the California Current System: Thecosome pteropods, heteropods, and foraminifera. Geophys Res Lett 36:L18608. doi:10.1029/2009 g1039901

Orr JC (2011) Recent and future changes in ocean carbonate chemistry. In: Gattuso J-P, Hansson L (eds) Ocean acidification. Oxford University Press, Oxford, pp 41-66

Orr JC, Fabry VJ, Aumont O, Bopp L, Doney SC, Feely RA, Gnanadesikan A, Gruber N, Ishida A, Joos F, Key RM, Lindsay K, Maier-Reimer E, Matear R, Monfray P, Mouchet A, Najjar RG, Plattner GK, Rodgers KB, Sabine CL, Sarmiento JL, Schlitzer R, Slater RD, Totterdell IJ, Weirig MF, Yamanaka Y, Yool A (2005) Anthropogenic ocean acidification over the twenty-first century and its impact on calcifying organisms. Nature 437:681-686

Parker LM, Ross PM, O'Connor WA (2009) The effect of ocean acidification and temperature on the fertilization and embryonic development of the Sydney rock oyster Saccostrea glomerata (Gould 1850). Glob Chang Biol 15:2123-2136. doi:10.1111/ j.1365-2486.2009.01895.x

Parker LM, Ross PM, O'Connor WA (2010) Comparing the effect of elevated $\mathrm{pCO}_{2}$ and temperature on the fertilization and early development of two species of oysters. Mar Biol 157:24352452. doi:10.1007/s00227-010-1508-3

Parker LM, Ross PM, O'Connor WA (2011) Populations of the Sydney rock oyster, Saccostrea glomerata, vary in response to ocean acidification. Mar Biol 158:689-697. doi:10.1007/s00227010-1592-4

Parker LM, Ross PM, O'Connor WA, Borysko L, Raftos DA, Pörtner H-O (2012) Adult exposure influences offspring response to ocean acidification in oysters. Glob Chang Biol (in press). doi: 10.1111/j.1365-2486.2011.02520.x

Peperzak L, Poelman M (2008) Mass mussel mortality in The Netherlands after a bloom of Phaeocystis globosa (prymnesiophyceae). J Sea Res 60:220-222. doi:10.1016/j.seares.2008. 06.001

Pipe RK, Coles JA (1995) Environmental contaminants influencing immune function in marine bivalve mollusks. Fish Shellfish Immunol 5:581-595

Pörtner HO, Farrell AP (2008) Physiology and climate change. Science 322:690-692

Pörtner HO, Langenbuch M, Reipschlager A (2004) Biological impact of elevated ocean $\mathrm{CO}_{2}$ concentrations: lessons from animal physiology and earth history. J Oceanogr 60:705-718. doi:10.1007/s10872-004-5763-0

Provoost P, van Heuven S, Soetaert K, Laane RWPM, Middelburg JJ (2010) Seasonal and long-term changes in $\mathrm{pH}$ in the Dutch 
coastal zone. Biogeosciences 7:3869-3878. doi:10.5194/bg-73869-2010

Range P, Chícharo MA, Ben-Hamadou R, Piló D, Matias D, Joaquim S, Oliveira AP, Chícharo L (2011) Calcification, growth and mortality of juvenile clams Ruditapes decussatus under increased $\mathrm{pCO}_{2}$ and reduced $\mathrm{pH}$ : variable responses to ocean acidification at local scales? J Exp Mar Biol Ecol 396:177-184

Range P, Piló D, Ben-Hamadou R, Chícharo MA, Matias D, Joaquim S, Oliveira AP, Chícharo L (2012) Seawater acidification by $\mathrm{CO}_{2}$ in a coastal lagoon environment: effects on life history traits of juvenile mussels Mytilus galloprovincialis. J Exp Mar Biol Ecol 424-425:89-98

Reuter KE, Lotterhos KE, Crim RN, Thompson CA, Harley CDG (2011) Elevated $\mathrm{pCO}_{2}$ increases sperm limitation and risk of polyspermy in the red sea urchin Strongylocentrotus franciscanus. Glob Chang Biol 17:163-171. doi:10.1111/j.13652486.2010.02216.x

Reynaud S, Leclercq N, Riomaine-Lioud S, Ferrier-Pagès C, Jaubert J, Gattuso J-P (2003) Interacting effects of $\mathrm{CO}_{2}$ partial pressure and temperature on photosynthesis and calcification in a scleractinian coral. Glob Chang Biol 9:1660-1668

Ries JB, Cohen AL, McCorkle DC (2009) Marine calcifiers exhibit mixed responses to $\mathrm{CO}_{2}$-induced ocean acidification. Geology 37:1131-1134. doi:10.1130/g30210a.1

Ringwood AH, Keppler CJ (2002) Water quality variation and clam growth: is pH really a non-issue in estuaries? Estuaries 25:901-907

Roberts D, Howard WR, Moy AD, Roberts JL, Trull TW, Bray SG, Hopcroft RR (2011) Interannual pteropod variability in sediment traps deployed above and below the aragonite saturation horizon in the Sub-Antarctic Southern Ocean. Polar Biol 34:1739-1750. doi:10.1007/s00300-011-1024-z

Rodolfo-Metalpa R, Houlbreque F, Tambutte E, Boisson F, Baggini C, Patti FP, Jeffree R, Fine M, Foggo A, Gattuso JP, HallSpencer JM (2011) Coral and mollusc resistance to ocean acidification adversely affected by warming. Nat Clim Chang $1: 308-312$

Roger LM, Richardson AJ, McKinnon AD, Knott B, Matear R, Scadding C (2012) Comparison of the shell structure of two tropical Thecosomata (Creseis acicula and Diacavolinia longirostris) from 1963 to 2009: potential implications of declining aragonite saturation. ICES J Mar Sci 69:465-474. doi: 10.1093/icesjms/fsr171

Rothschild BJ, Ault JS, Goulletquer P, Heral M (1994) Decline of the Chesapeake Bay oyster population-a century of habitat destruction and overfishing. Mar Ecol Prog Ser 111:29-39

Saha A, Jana TK (1999) Biocalcification of aragonite by tellinid bivalve Macoma birmanica (Philippi) on the tidal mudflat in the Sundarban mangrove forest, north-east coast of India. Ind J Mar Sci 28:404-407

Salisbury J, Green M, Hunt C, Campbell J (2008) Coastal acidification by rivers: a new threat to shellfish? Eos Trans AGU 89:513

Schalkhausser B, Bock C, Stemmer K, Brey T, Pörtner H-O, Lannig $G$ (2012) Impact of ocean acidification on escape performance of the king scallop, Pecten maximus, from Norway. Mar Biol 1-12. doi:10.1007/s00227-012-2057-8

Schöne BR, Tanabe K, Dettman DL, Sato S (2003) Environmental controls on shell growth rates and $\delta^{18} \mathrm{O}$ of the shallow marine bivalve mollusk Phacosoma japonicum in Japan. Mar Biol 142:473-485. doi:10.1007/s00227-002-0970-y

Seibel BA, Walsh PJ (2003) Biological impacts of deep-sea carbon dioxide injection inferred from indices of physiological performance. J Exp Biol 206:641-650. doi:10.1242/jeb.00141

Seibel BA, Maas AE, Dierssen HM (2012) Energetic plasticity underlies a variable response to ocean acidification in the pteropod, Limacina helicina antarctica. PLoS ONE 7. doi: 10.1371/journal.pone.0030464
Shirayama Y, Thornton H (2005) Effect of increased atmospheric $\mathrm{CO}_{2}$ on shallow water marine benthos. J Geophys Res Oceans 110:C09S08. doi:10.1029/2004jc002618

Sindermann CJ (1990) Principal diseases of marine fish and shellfish. Vol II. Diseases of marine shellfish. Academic Press, San Diego

Smith SV (1972) Production of calcium carbonate on the mainland shelf of southern California. Limnol Oceanogr 17:28-41

Smith SV, Key GS (1975) Carbon dioxide and metabolism in marine environments. Limnol Oceanogr 20:493-495

Steinacher M, Joos F, Frölicher TL, Plattner GK, Doney SC (2009) Imminent ocean acidification in the Arctic projected with the NCAR global coupled carbon cycle-climate model. Biogeosciences 6:515-533

Sunday JM, Crim RN, Harley CDG, Hart MW (2011) Quantifying rates of evolutionary adaptation in response to ocean acidification. PLoS ONE 6. doi:10.1371/journal.pone.0022881

Suzuki Y, Kojima S, Watanabe H, Suzuki M, Tsuchida S, Nunoura T, Hirayama H, Takai K, Nealson KH, Horikoshi K (2006) Single host and symbiont lineages of hydrothermalvent gastropods Ifremeria nautilei (Provannidae): biogeography and evolution. Mar Ecol Prog Ser 315:167-175

Talmage SC, Gobler CJ (2009) The effects of elevated carbon dioxide concentrations on the metamorphosis, size, and survival of larval hard clams (Mercenaria mercenaria), bay scallops (Argopecten irradians), and Eastern oysters (Crassostrea virginica). Limnol Oceanogr 54:2072-2080

Talmage SC, Gobler CJ (2010) Effects of past, present, and future ocean carbon dioxide concentrations on the growth and survival of larval shellfish. Proc Natl Acad Sci USA 107:17246-17251. doi:10.1073/pnas.0913804107

Talmage SC, Gobler CJ (2011) Effects of elevated temperature and carbon dioxide on the growth and survival of larvae and juveniles of three species of Northwest Atlantic bivalves. PLoS ONE 6:e26941

Talmage SC, Gobler CJ (2012) Effects of $\mathrm{CO}_{2}$ and the harmful alga Aureococcus anophagefferens on growth and survival of oyster and scallop larvae. Mar Ecol Prog Ser 464:121-134. doi: 10.3354/meps09867

Thiyagarajan V, Ko GWK (2012) Larval growth response of the Portuguese oyster (Crassostrea angulata) to multiple climate change stressors. Aquaculture 370-371:90-95. doi:10.1016/ j.aquaculture.2012.09.025

Thomsen J, Melzner F (2010) Moderate seawater acidification does not elicit long-term metabolic depression in the blue mussel Mytilus edulis. Mar Biol 157:2667-2676. doi:10.1007/s00227010-1527-0

Thomsen J, Gutowska MA, Saphorster J, Heinemann A, Trubenbach K, Fietzke J, Hiebenthal C, Eisenhauer A, Kortzinger A, Wahl M, Melzner F (2010) Calcifying invertebrates succeed in a naturally $\mathrm{CO}_{2}$-rich coastal habitat but are threatened by high levels of future acidification. Biogeosciences 7:3879-3891. doi: $10.5194 /$ bg-7-3879-2010

Timmins-Schiffman E, O'Donnell M, Friedman C, Roberts S (2012) Elevated $p \mathrm{CO}_{2}$ causes developmental delay in early larval Pacific oysters, Crassostrea gigas. Mar Biol 1-10. doi:10.1007/ s00227-012-2055-x

Tomanek L, Zuzow MJ, Ivanina AV, Beniash E, Sokolova IM (2011) Proteomic response to elevated $p \mathrm{CO}_{2}$ level in Eastern oysters, Crassostrea virginica: evidence for oxidative stress. J Exp Biol 214:1836-1844. doi:10.1242/jeb.055475

Tunnicliffe V, Davies KTA, Butterfield DA, Embley RW, Rose JM, Chadwick WW (2009) Survival of mussels in extremely acidic waters on a submarine volcano. Nat Geosci 2:344-348. doi: 10.1038 /ngeo500

Van Colen C, Debusschere E, Braeckman U, Van Gansbeke D, Vincx M (2012) The early life history of the clam Macoma balthica in a 
high $\mathrm{CO}_{2}$ world. PLoS ONE 7:e44655. doi:10.1371/journal. pone. 0044655

Waldbusser GG, Bergschneider H, Green MA (2010) Size-dependent $\mathrm{pH}$ effect on calcification in post-larval hard clam Mercenaria spp. Mar Ecol Prog Ser 417:171-182. doi:10.3354/meps08809

Waldbusser GG, Steenson RA, Green MA (2011a) Oyster shell dissolution rates in estuarine waters: effects of $\mathrm{pH}$ and shell legacy. J Shellfish Res 30:659-669. doi:10.2983/035.030.0308

Waldbusser GG, Voigt EP, Bergschneider H, Green MA, Newell RIE (2011b) Biocalcification in the Eastern oyster (Crassostrea virginica) in relation to long-term trends in Chesapeake Bay $\mathrm{pH}$. Estuaries Coast 34:221-231. doi:10.1007/s12237-010-9307-0

Waller TR (1981) Functional morphology and development of veliger larvae of the European oyster, Ostrea edulis Linné. Smithson Contrib Zool 328:1-70

Walther K, Sartoris FJ, Bock C, Pörtner HO (2009) Impact of anthropogenic ocean acidification on thermal tolerance of the spider crab Hyas araneus. Biogeosciences 6:2207-2215

Watson S-A, Southgate PC, Tyler PA, Peck LS (2009) Early larval development of the Sydney Rock oyster Saccostrea glomerata under near-future predictions of $\mathrm{CO}_{2}$-driven ocean acidification. J Shellfish Res 28:431-437. doi:10.2983/035.028.0302

Watson SA, Peck LS, Tyler PA, Southgate PC, Tan KS, Day RW, Morley SA (2012a) Marine invertebrate skeleton size varies with latitude, temperature and carbonate saturation: implications for global change and ocean acidification. Glob Chang Biol 18:3026-3038. doi:10.1111/j.1365-2486.2012.02755.x

Watson SA, Southgate PC, Miller GM, Moorhead JA, Knauer J (2012b) Ocean acidification and warming reduce juvenile survival of the fluted giant clam, Tridacna squamosa. Molluscan Res 32:177-180

Weiner S, Dove PM (2003) An overview of biomineralization processes and the problem of the vital effect. Rev Mineral Geochem 54:1-29. doi:10.2113/0540001
Weiner S, Traub W (1984) Macromolecules in mollusk shells and their functions in biomineralization. Philos Trans R Soc Lond Ser B Biol Sci 304:425-434

Welladsen HM, Southgate PC, Heimann K (2010) The effects of exposure to near-future levels of ocean acidification on shell characteristics of Pinctada fucata (Bivalvia: Pteriidae). Molluscan Res 30:125-130

Wheeler AP (1992) Mechanisms of molluscan shell formation. In: Bonucci E (ed) Calcification in biological systems. CRC Press, Boca Raton, pp 179-215

Wicks LC, Roberts JM (2012) Benthic invertebrates in a high- $\mathrm{CO}_{2}$ world. In: Gibson RN, Atkinson RJA, Gordon JDM, Hughes RN (eds) Oceanography and marine biology: an annual review, vol 50, pp 127-187

Wilson SP, Hyne RV (1997) Toxicity of acid-sulfate soil leachate and aluminium to embryos of the Sydney rock oyster. Ecotoxicol Environ Saf 37:30-36

Winter JE (1978) Review on knowledge of suspension-feeding in lamellibranchiate bivalves, with special reference to artificial aquaculture systems. Aquaculture 13:1-33. doi:10.1016/00448486(78)90124-2

Wootton JT, Pfister CA, Forester JD (2008) Dynamic patterns and ecological impacts of declining ocean $\mathrm{pH}$ in a high-resolution multi-year dataset. Proc Natl Acad Sci USA 105:18848-18853. doi:10.1073/pnas.0810079105

Yates KK, Halley RB (2006) Diurnal variation in rates of calcification and carbonate sediment dissolution in Florida Bay. Estuaries Coast 29:24-39

Zippay ML, Hofmann GE (2010) Effect of pH on gene expression and thermal tolerance of early life history stages of red abalone (Haliotis rufescens). J Shellfish Res 29:429-439. doi:10.2983/ 035.029.0220 